Portland State University

PDXScholar

$1-1-2011$

\title{
Capital Flows, Political Performance, and Development
}

Ayesha Umar Wahedi

Portland State University

Follow this and additional works at: https://pdxscholar.library.pdx.edu/open_access_etds Let us know how access to this document benefits you.

\section{Recommended Citation}

Umar Wahedi, Ayesha, "Capital Flows, Political Performance, and Development" (2011). Dissertations and Theses. Paper 217.

https://doi.org/10.15760/etd.217

This Dissertation is brought to you for free and open access. It has been accepted for inclusion in Dissertations and Theses by an authorized administrator of PDXScholar. Please contact us if we can make this document more accessible: pdxscholar@pdx.edu. 
Capital Flows, Political Performance, and Development

by

Ayesha Umar Wahedi

A dissertation submitted in partial fulfillment of the requirements for the degree of

Doctor of Philosophy
in

Public Affairs and Policy

Dissertation Committee:

Birol Yesilada, Chair

Ronald Tammen

Phillip Cooper

David Kinsella

Marina Arbetman-Rabinowitz

John Gallup

Portland State University

(C)2011 


\begin{abstract}
This research explores the impact of various forms of capital flows on economic growth and development for a group of 120 countries from 1980-2007. Traditional growth literature as well as the textbook theory of economic growth looks at capital flows as playing a vital role in fostering economic growth and development. The textbook theories, as well as the existing approaches to study the capital flows and economic development connection, use growth and development interchangeably. This analysis, examines the consequences of different capital flows on growth and development separately because the determinants of growth may not be the same as the determinants of development. This distinction becomes even more applicable when observing the cases of countries that have experienced economic growth during certain periods but were unable to translate the increase in economic growth to development. To investigate the impact of various forms of capital flows, this dissertation utilizes life expectancy in addition to economic growth, as a measure of development. The results from using the two measures show that capital flows have dissimilar impact on life expectancy as well as economic growth.

The central proposition of this dissertation is that not all forms of capital flows are created equal. Furthermore, countries at different levels of development may differ in their absorptive capacity of the capital. Thus, the ability of a country to harness capital for development depends upon its absorptive capacity, presence of domestic resources
\end{abstract}


and the capabilities of national governments. This study therefore not only looks at the role played by various forms of capital flows on growth and development, but also takes into account the role of political performance of national governments that can play an important role in maximizing the efficiency of the investments. To investigate what kinds of flows are beneficial at different levels of development, this analysis further divides the dataset into three samples of developed countries, emerging markets and less developed countries. The results indicate that the impact of different capital flows varies across the three subsamples.

By categorizing capital flows into categories of international capital flows, domestic capital, and remittances, this research also finds that the type of investment, as well as the source of investment (foreign vs. domestic), indeed does matter. The analysis suggests that the key to harnessing capital for development lies with capable governments and efficient use of domestic resources. In absence of capable governments, influx of foreign capital flows can manifest itself in ways that are harmful to the progress of developing societies. 


\section{Acknowledgments}

I am extremely indebted to my dissertation committee for their support and guidance throughout the process of this dissertation. I am very fortunate to have a committee where every member contributed to my knowledge and understanding in a unique way and without their help, I would not be here today. I am very grateful to my advisor Dr. Birol Yesilada for his contribution to my knowledge of the subject matter and his constant encouragement and help in the timely completion of this dissertation. I couldn't thank Dr. Ron Tammen enough for being a great resource and helping me work through numerous challenges. Dr. Philip Cooper has contributed greatly to my thinking from the day I started the doctoral program. Not only has he constantly encouraged me to become a more careful writer, his insights have always challenged me and have brought a fresh perspective to my work. I would also like to thank Dr. David Kinsella for his thought provoking insights that have helped bring more clarity and rigor to my work.

I am immensely indebted to Dr. Marina Arbetman-Rabinowitz for her help in every step of the way. Her constant guidance has not only helped shaped this project but her emphasis on familiarizing myself with every aspect of the data, validation and revalidation of every result, and her critical feedback has helped me become a better researcher. Having Dr. Arbetman-Rabinowitz as a mentor has been an invaluable experience and I am extremely grateful to her for her constant guidance. I would also like to thank Dr. John Luke Gallup for his generosity with his time, spending numerous hours 
with me and working through the technical details of my research. Not only has Dr. Gallup helped me greatly in modeling issues, but has also introduced me to a vast literature that has helped improved my research. I have learned immensely from my interactions with Dr. Gallup for which I am most grateful.

I am also grateful to Dr. Hiro Ito for the numerous thought provoking discussions and for pointing me to a vast literature in international finance. I would also like to thank KyungKook Kang and Kristin Johnson for several helpful discussions regarding data issues and results as well as my colleagues at Portland State University for their support and making the past five years a most memorable experience.

Finally, without the love and support of my family, I would not be here today. My parents have always pushed me to pursue my academic goals and have always provided their encouragement. My husband, Samad Wahedi has been there at every step of the way, I couldn't thank him enough for his love and support. 


\section{Table of Contents}

Abstract
Acknowledgments
List of Tables
List of Figures
List of Abbreviations

Chapter 1 - Introduction $\ldots \ldots \ldots \ldots$

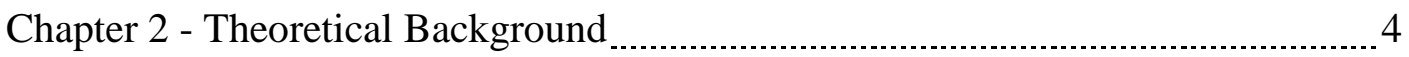

Chapter 3 - Model of Analysis $\quad 40$

Chapter 4 - Analysis and Findings $\ldots$

Chapter 5 - Conclusion and Implications

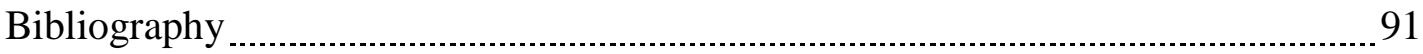

Appendix A- Country Samples $\ldots$

Appendix B - Data Definitions and Sources …………………………………..... 99

Appendix C - Statistical Tables OLS Results $\ldots$

Appendix D - Statistical Tables Fixed Effects Results _........................................... 106

Appendix E - Statistical Tables Cross-Section Results _............................................ 112

Appendix F - Correlation Matrix $\ldots \ldots$ 


\section{List of Tables}

Table 1 - FDI Flows by Region 2007-2009 13

Table 2 - Summary Statistics for the Whole Sample $\ldots \ldots \ldots \ldots$

Table 3 - Summary Statistics DC

Table 4 - Summary Statistics EFM 56

Table 5 - Summary Statistics LDC 57

Table 6 - Panel Data Analysis using Prais-Winsten Regression: Whole Sample ..... 68

Table 7 - Panel Data Analysis using Prais-Winsten Regression: DC Sample _.......... 71

Table 8 - Panel Data Analysis using Prais-Winsten Regression: EFM Sample _........ 74

Table 9 - Panel Data Analysis using Prais-Winsten Regression: LDC Sample _........ 77

Table 10 - Panel Data Analysis using Prais-Winsten Regression: LDC Sample _...... 80

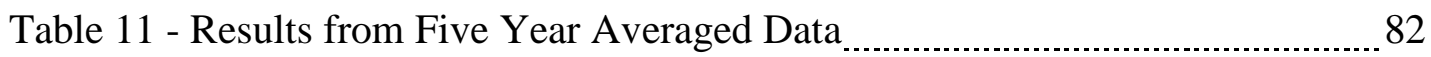




\section{List of Figures}

Figure 1 - Relative GDP per Capita of Capital Exporters and Capital Importers: 19752005 5

Figure 2 - Savings, Investment and Economic Growth in the Textbook Model $\ldots . . .7$

Figure 3 - Adjusted Savings in 1981-1985 8

Figure 4 - Adjusted Savings in 2006-2010

Figure 5 - Global FDI Flows 2002-2009 and projections for 2010-2012 _............ 12

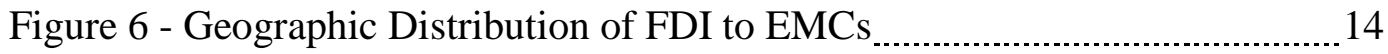

Figure 7 - Remittances in LDCs

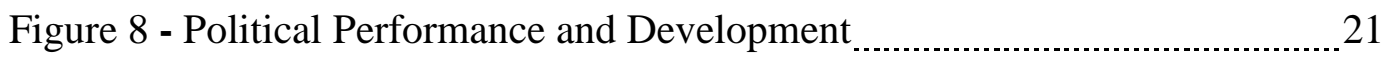

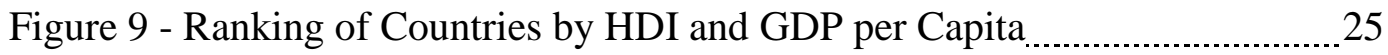

Figure 10 - Ranking of Countries by HDI and log GDP per Capita _.................. 25 


\section{List of Abbreviations}

\begin{tabular}{|c|c|c|}
\hline BRIC & - & Brazil Russia India China \\
\hline $\mathrm{DC}$ & - & Developed Countries (High Income Countries) \\
\hline EFM & - & Emerging Financial Markets \\
\hline FDI & - & Foreign Direct Investment \\
\hline FPI & - & Foreign Portfolio Investment \\
\hline HDI & - & Human Development Indicator \\
\hline HDR & - & Human Development Report \\
\hline IFS & - & International Financial Statistics \\
\hline IMF & - & International Monetary Fund \\
\hline LDC & - & Less Developed Countries \\
\hline LLDC & - & Landlocked Developing Countries \\
\hline ODA & - & Official Development Assistance \\
\hline OECD & - & Organization for Economic Co-operation and Development \\
\hline OFI & - & Other Financial Investment \\
\hline RPE & - & Relative Political Extraction \\
\hline SIDS & - & Small Island Developing States \\
\hline UNCTAD & - & United Nations Conference on Trade and Development \\
\hline
\end{tabular}




\section{Chapter - 1}

\section{Introduction}

Adam Smith devoted an entire volume to the timeless question of "How do nations prosper and what polices ensure their wealth?" (Smith 1776 in Kehl 2008:4); the goal of this research is to revisit this age-old question in the context of the global economy by exploring the relative importance of the economic and political determinants of the wealth of nations as well as addressing how wealth can be translated into welfare of societies. To address this question, this dissertation looks at the impact of economic factors in the form of capital, both foreign and domestic, and political performance on the wealth as well as the welfare components of development.

Foreign capital has been at the forefront of economic globalization. Foreign capital flows take the form of foreign direct investment, foreign portfolio investments, other (loans and equity) financial investments, remittances etc. In the wake of the economic crisis that began in 2008, understanding these flows and their economic and political ramifications for host countries has become more important than ever. The International Monetary Fund (IMF) has stated that "the key policy challenge will be attracting and harnessing healthy capital flows to restore economic growth." (Brogger, East Europe's Main Challenge is Guiding Capital Flows 2010) The Asian Development Bank has also advised emerging markets in Asia to manage their capital flows, as flows 
rebound to $\$ 272.4$ billion in 2010 , mainly driven by the rise in portfolio equity flows. (Brown 2010) Although financial globalization does bring many benefits such as capital, knowledge and discipline (Tong and Wei 2009), the crisis of 2008 has shown that there is a perverse side to the influx of capital because of the reversible nature of short term capital.

The discussion on the developmental impacts of the various forms of capital flows is very scant in the literature and empirical evidence is inconclusive. Although a growing body of literature has looked at the impact of financial development and growth, much needs to be said of the "welfare effects of the composition of capital flows" (Tong and Wei 2009). Moreover, the studies that do look at the impact of capital flows on growth, consider the measures of flows that are available instead of focusing on what is relevant for the developmental level and political performance of a country. This paper attempts to fill the gap in literature by looking at how different forms of capital flows affect growth as well as development in developing countries.

This study differs from existing approaches to study the capital flows and development connection in several fundamental ways. First, the analysis, following the approach of Prasad, Rajan and Subramanian (2007), uses current account balance as a composite measure to address the question of whether foreign capital plays a role in development. However, to assess the welfare effects of various forms of flows, the individual effects of foreign direct investment, portfolio investment and other (short term) capital flows, alongside remittances and domestic savings is investigated. The role of politics is also formalized in this analysis by looking at the impact of the political performance of national governments in bringing about economic performance. Finally, 
to address the fundamental question of whether growth translates into development, the impact of the economic and political variables noted above, is investigated on Life Expectancy at birth as a measure of development for middle to low income developing countries.

The central proposition of this study is that the all forms of capital are not equal. The capacity to absorb foreign investments and harness it for development depends on the type of investment, presence of domestic resources and the capabilities of national governments. Countries that do not have a capable government find it hard to harness foreign investment for developmental objectives, but may have more success by utilizing domestic capital. This conjecture is confirmed by the findings of this research which shows that relatively less reliance on foreign capital is positively associated with growth as well as development in low and middle income developing countries.

This dissertation is organized as follows. Chapter 2 looks at the main strands of theoretical and empirical literature regarding the capital-development nexus. The first strand considers the issue of growth vs. development. The second set of literature looks at the capital flows and growth connection in general, as well as specific studies that examine the developmental impacts of various kinds of capital flows such as foreign direct investment, portfolio investment, remittances etc. in developing countries. The last strand of literature examines the politics and growth connection. Chapter 3 discusses the methodology that is employed in conducting this research and explains the choice of variables and the data sources. Chapter 4 reports the results and offers potential policy implications of this research and Chapter 5 concludes and addresses limitation of this research and offers future direction of research. 


\section{Chapter - 2}

\section{Theoretical Background}

The objective of this chapter is to provide a background on the capital and development debate by providing formal definitions and reviewing the state of existing literature on the capital flows and development link. This connection raises several relevant questions. First, does the inflow of foreign capital bring about growth in developing countries or is it domestic sources of finance that are the key to bringing about development? Second, does economic growth occur at the expense of development? Third, what is the role of politics in this process? These questions have very important implications for the development of poor societies and have been extensively discussed in the fields of economics, political science, sociology, as well as the multidisciplinary study of sustainable development. To address these issues, it is important to understand the different forms of capital. What do we mean by development and how do we measure it; what is political performance and why it is relevant to this debate? The main economic and political determinants of development considered in this study include various forms of foreign capital flows as well as domestic sources of financing; a measure of political performance is used to assess the capability of national governments. 


\section{Current Account Balance}

To investigate whether foreign capital plays an important role in development by augmenting domestic resources, examining current account balance is a good place to start. The choice of current account balance as an aggregate measure on foreign capital inflows is motivated by Prasad, Rajan and Subramanian 2007. Current account balance “is equivalent to a country's saving less its investment, provides a summary measure of the net amount of capital, including private and official capital, flowing in or out of a country." (Prasad et al. 2007: 154) According to this definition, current account surplus corresponds to the net amount of capital leaving the country, or, in other words, an excess of domestic savings over domestic investment. Similarly, current account deficit shows the opposite picture, i.e. excess of domestic investment over domestic savings, which indicates that foreign financing is picking up the difference. Figure 1 shows the global trends in current account surplus and current account deficits from 1975 through 2005.

Figure 1: Relative GDP per Capita of Capital Exporters and Capital Importers: 19752005



Source: (Prasad, Rajan and Subramanian 2007: 155) 
The problem however, with only using current account balance as the exclusive measure to study the impact of capital flows on growth as done by Prasad et al. (2007) is that it is a homogenous measure and does not tell us anything about the welfare compositions of various forms of capital flows. Additionally, in the time period 19802007, considered for this research, developing countries included in the sample have undergone some dramatic changes in their composition of various forms of capital flows ${ }^{1}$, therefore it is important to consider the impact of various flows on development, separately. Although current account balance gives an idea of whether countries are net exporters of capital or net importers of capital, it is also important to look at the channels through which domestic investment is financed.

Domestic Savings

Domestic savings here are defined as gross national savings less the value of consumption of fixed capital. (World Bank 2010) According to traditional text book model, there are two methods of financing domestic investments, foreign savings, and domestic savings. It has been argued that domestic savings provide the most sustainable form of investment in most countries (Prasad et al. 2007).

Studying the impact of domestic savings on growth and development in this model allows us to test the traditional view that "foreign capital permits capitalconstrained poor countries to expand domestic investment and thereby increase growth." (Prasad et al. 2007) If this is indeed true, the relationship between domestic savings and

\footnotetext{
${ }^{1}$ While the beginning of 1980 was marked by high bank debt, in the aftermath of the debt crisis the role of banks diminished as major players in the early1990s. Instead, the 1990s saw an increase in private investments which coincided with the fall of communism and opening up of the transition economies of
} 
growth should be negative or insignificant hence encouraging the need for foreign sources of financing. Figure 2 below plots savings (S curve) and investment (I curve) against real interest in two scenarios. When the economy is closed to foreign capital, equilibrium is at point $B$ with $r_{d o m}$ as the interest rate; however once the economy is opened to foreign capital, increase in capital flows brings the new equilibrium at point $\mathrm{C}$ and lowers the interest rate to $\mathrm{r}^{*}$. Decrease in interest rate according to this textbook model leads to higher investment which leads to higher growth. ${ }^{2}$

Figure 2: Savings, Investment and Economic Growth in the Textbook Model



Source: Prasad, Rajan and Subramanian 2007:167

\footnotetext{
${ }^{2}$ This discussion draws upon the analysis of Prasad, Rajan and Subramanian (2007) and the choice of domestic savings as a measure of domestic resources is also motivated by their analysis.
} 
The following figures (Figure 3 and Figure 4) compare geographic dispersion of worldwide savings in 1981-1985 and 2006-2010. The figures below represent how the attitudes in savings worldwide have shifted dramatically during the time period considered in this analysis.

Figure 3: Adjusted Savings in 1981-1985

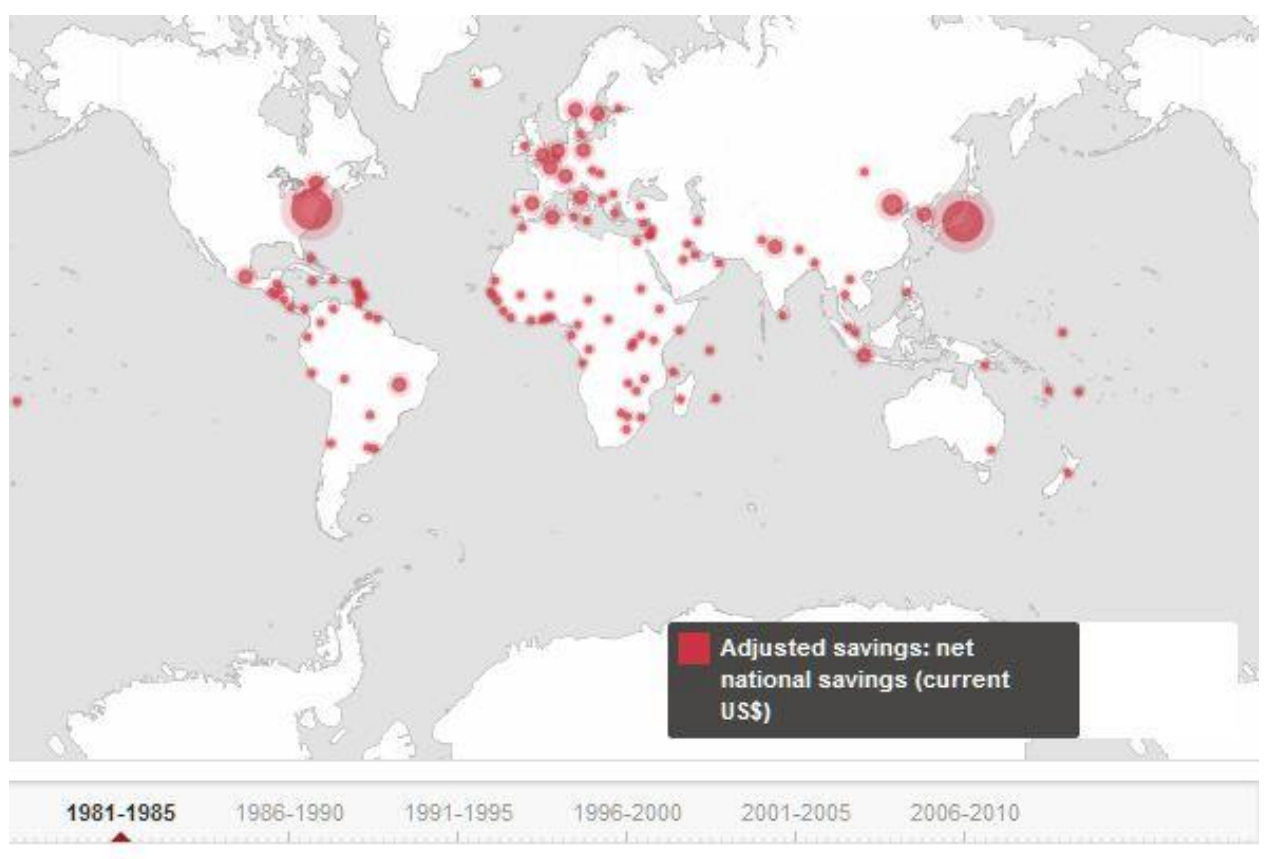

Source: World Bank, World Development indicators 2010:

http://data.worldbank.org/ 
Figure 4: Adjusted Savings in 2006-2010



Source: World Bank, World Development indicators 2010: http://data.worldbank.org/

As can be seen from the map, savings in the developing world increased dramatically from the 1980s levels in Latin America and East Asia in 2006-2010. United States and Japan dominate the map in terms of savings in Figure 3, show a decline in Figure 4, followed by a dramatic increase in China's savings. However, not all countries in the developing world have experienced high savings for several reasons such as low interest rates and lack of domestic investment opportunities. Kamewe-Tsafack (2010) notes that while Latin America and East Asia showed average gross savings rates as high as $22 \%$ and $35 \%$ respectively, the savings rate in Sub-Saharan Africa has been a modest $16 \%$, "with some countries displaying modest domestic savings rates (for example 
Guinea 3\%, Burundi 4\%, Mozambique and Ghana 7\%) to relatively robust savings rates (for example Lesotho 22\%, Rwanda 27\%, and Mali 28\%).” (Kamewe-Tsafack 2010:1)

There are many reasons why domestic savings can be expected to positively influence growth and economic stability. A high saving rate may make an economy less vulnerable to macroeconomic instability and external shocks that reverse other forms of capital flows. Furthermore, while

investment can be financed with either internal or foreign resources, the empirical evidence shows that when external borrowings exceed a certain threshold, even highly successful economies begin to have trouble to service their foreign debt. (Calafell 2003)

For this analysis, the inclusion of domestic savings allows us to address whether growth financed by domestic resources reduces external vulnerability by reducing dependence on foreign capital as well as aid. In addition to the earlier noted composite measure of capital and domestic savings, the following forms of foreign investment are considered in this analysis.

\section{Foreign Direct Investment}

According to the IMF's Balance of Payments Manual, 5th edition, Foreign Direct Investment (FDI) "reflecting the lasting interest of a resident entity in one economy (direct investor) in an entity resident in another economy (direct investment enterprise)covers all transactions between direct investors and direct investment enterprises. ${ }^{33}$ The literature in economics has particularly focused on the role of FDI as the engine of

\footnotetext{
${ }^{3}$ For the purpose of this analysis, FDI flows instead of FDI stock are considered. The reason for using flows instead of stocks is that a change in stock can result from a number of factors including changes in flows, changes in exchange rates or other adjustments etc., flows on the other hand reflect only transactions are more relevant from a policy perspective.
} 
economic growth. Various empirical studies argue that FDI has a positive impact on growth by augmenting resources as well as transferring technology. However, some make the case that the effect of FDI on development depends on the sector as well as the motivations, i.e. whether FDI is resource-seeking or market-seeking (Cohen 2007; Moran 2005). For instance, Moran (2005) looks at two categories of FDI viz., manufacturing and assembly, and natural resources and infrastructure. His findings demonstrate that depending on the sector as well as the condition in the host country, FDI can offer great benefits and yet at the same time, under a different set of conditions, FDI may be very detrimental for the development of poor countries. Looking at disaggregated FDI by sector is outside the scope of this project but does provide direction for future research.

A majority of literature does consider FDI a relatively more stable form of capital flows. As a result a large number of empirical studies on capital flows and growth focus primarily on FDI. According to the World Bank report on Global Development Finance (2006), "FDI tends to be more stable than debt, in the sense that current FDI is strongly correlated to its past levels." (2006:143) This assertion has been put to test by the recent downturn and the consequent reduction in all forms of capital flows, including FDI. Nevertheless, the last decade has seen a predominant shift in the composition of capital towards FDI. This trend has been especially true for the countries that were adversely affected by the East Asian currency crisis in 1997. Figure 5 below shows trends in FDI and projections for the future. According to the figure, despite a drastic decline in FDI during the recession, FDI flows are recovering. This recovery is primarily led by developing and transition economies which absorbed half of world FDI flows in 2009. 
Figure 5: Global FDI Flows 2002-2009 and projections for 2010-2012

(Billions of dollars)

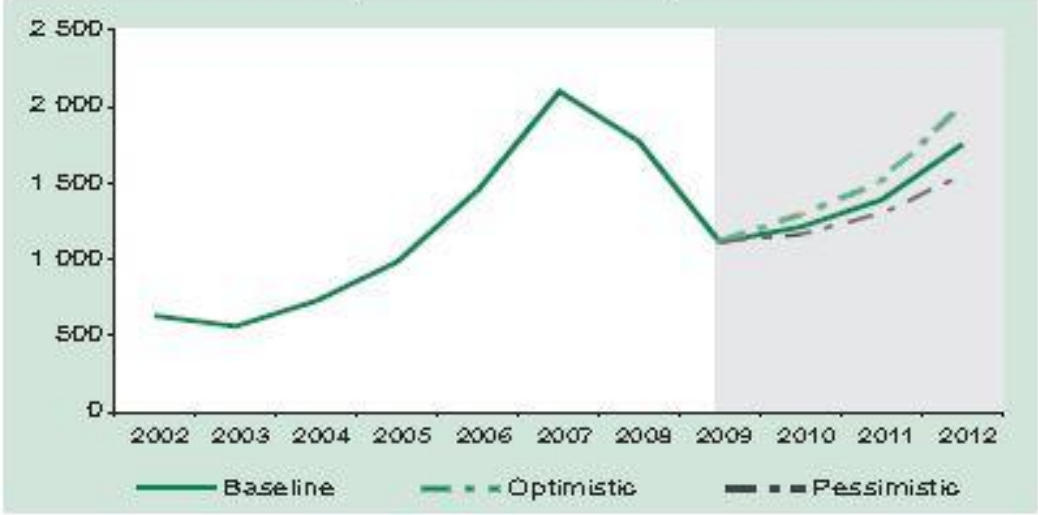

Source: UNCTAD World Investment Report 2010:2

Furthermore, even though half of the world's FDI goes to developing countries, in 2009 only $0.4 \%$ of the world FDI went to structurally weak and vulnerable economies comprised of least developed countries (LDCs), landlocked developing countries (LLDCs) and Small Island developing states (SIDS).(UNCTAD 2010). The following table shows a composition of global FDI flows by region. 
Table 1: FDI Flows by Region 2007-2009

\begin{tabular}{|c|c|c|c|c|c|c|}
\hline \multirow{2}{*}{ Region } & \multicolumn{3}{|c|}{ FDlinflows } & \multicolumn{3}{|c|}{ FDI outflows } \\
\hline & 2007 & 2008 & 2009 & 2007 & 2008 & 2009 \\
\hline World & 2100 & 1771 & 1114 & 2268 & 1929 & 1101 \\
\hline Developed economies & 1444 & 1018 & 566 & 1924 & 1572 & 821 \\
\hline Developing ec onomies & 565 & 630 & 478 & 292 & 296 & 229 \\
\hline Africa & 63 & 72 & 59 & 11 & 10 & 5 \\
\hline Latin America and the Caribbean & 164 & 183 & 117 & 56 & 82 & 47 \\
\hline West Asia & 78 & 90 & 68 & 47 & 38 & 23 \\
\hline South, East and South-East A sia & 259 & 282 & 233 & 178 & 166 & 153 \\
\hline South-East Europe and the ClS & 91 & 123 & 70 & 52 & 61 & 51 \\
\hline $\begin{array}{l}\text { Structurally weak, vulnerable and small } \\
\text { economies a }\end{array}$ & 42.5 & 62.1 & 50.5 & 5.3 & 5.8 & 4.2 \\
\hline LDCs & 26 & 32 & 28 & 2 & 3 & 1 \\
\hline LLDCs & 16 & 26 & 22 & 4 & 2 & 3 \\
\hline SIDS & 5 & 8 & 5 & 0 & 1 & 0 \\
\hline \multicolumn{7}{|l|}{$\begin{array}{l}\text { Memorandum: percentage share in } \\
\text { world FDi flows }\end{array}$} \\
\hline Developed economies & 68.8 & 57.5 & 50.8 & 84.8 & 81.5 & 74.5 \\
\hline Developing economies & 26.9 & 35.6 & 42.9 & 12.9 & 15.4 & 20.8 \\
\hline Africa & 3.0 & 4.1 & 5.3 & 0.5 & 0.5 & 0.5 \\
\hline Latin America and the Caribbean & 7.8 & 10.3 & 10.5 & 2.5 & 4.3 & 4.3 \\
\hline West Asia & 3.7 & 5.1 & 6.1 & 2.1 & 2.0 & 2.1 \\
\hline South, East an & 12.3 & 15.9 & 20.9 & 7.9 & 8.6 & 13.9 \\
\hline South-East Europe and $\mathrm{ClS}$ & 4.3 & 6.9 & 6.3 & 2.3 & 3.1 & 4.6 \\
\hline $\begin{array}{l}\text { Structurally weak, vulnerable and small } \\
\text { economies : }\end{array}$ & 2.0 & 3.5 & 4.5 & 0.2 & 0.3 & 0.4 \\
\hline LDCs & 1.2 & 1.8 & 2.5 & 0.1 & 0.2 & 0.1 \\
\hline LLDCs & 0.7 & 1.5 & 2.0 & 0.2 & 0.1 & 0.3 \\
\hline SIDS & 0.3 & 0.4 & 0.4 & 0.0 & 0.0 & 0.0 \\
\hline
\end{tabular}

Source: UNCTAD, World Investment Report 2010:6

UNCTAD estimated FDI flows in 2010 to be $\$ 1.2$ trillion, before picking up to \$1.3-1.5 trillion in 2011. Despite these trends, the evidence on the universal effects of FDI remains inconclusive. The pursuit of universal impact of FDI is further complicated by the large regional variation in FDI flows as depicted in figure 6 . In addition, all efforts to date look at the impact of FDI on growth in GDP per Capita and no study to date has 
looked at whether benefits from FDI if any translate into development measured differently from growth in GDP per Capita.

Figure 6: Geographic Distribution of FDI to EMCs



Source: UNCTAD 1990-2002, Balance of Payments Statistical Yearbook: 44

\section{Foreign Portfolio Investments}

According to the IMF Balance of Payments Manual, 5th edition, Foreign Portfolio Investment (FPI) is defined as "cross-border transactions and positions involving debt or equity securities, other than those included in direct investment or reserve assets." Some have argued that portfolio flows can also play an important role in developing domestic markets which in turn has a positive impact on growth (Gruben and McLeod (1998); Kyaw and Macdonald 2009). According to Vita and Kyaw (2009) "Portfolio investment 
flows can bolster economic growth by increasing the liquidity of domestic capital markets and by inducing greater market efficiency. As domestic markets become more liquid, deeper and broader, a wider range of projects can be financed, further stimulating growth and development." (2009: 277) However this theorized relationship between portfolio flows and growth has received much less attention in the empirical literature.

\section{Other Financial Investments}

The Other Financial Investment (OFI) category "is a residual category that includes positions and transactions other than those included in direct investment, portfolio investment, financial derivatives and employee stock options, and reserve assets" (IMF Balance of Payments Manual, 6th edition). This category includes trade credits, loans, currency, and deposits. Because data on these capital-flows are not readily available, especially for the low income developing countries, the impact of these flows has not been studied extensively in the literature.

Although FPI and OFI are considered by some to play an important role in growth, by impacting the financial development of host country's financial markets, their role is not extensively documented in the literature, with a few notable exceptions. Gruben and McLeod (1998) look at the impact of portfolio flows on growth for a small group of developing countries and find portfolio flows to be growth inducing. Others such as Mishra, Mody and Murshi (2001) find that portfolio flows develop domestic capital markets, which in turn affects growth. Iyer, Rambaldi, and Tang (2004) look at the spillover effects of various forms of capital flows such as FDI, FPI and OFI in 20 OECD countries. Their findings suggest that the spillover effects of FDI flows are greater 
than FPI and OFI and therefore "FDI flows are more growth inducing than alternative forms of foreign investment." (2004: 21) A drawback of their work is that it primarily focuses on a small number of OECD countries, and based on Blonigen and Wang (2005) and Egger and Winner (2006), OECD country findings are not generalizable to nonOECD countries.

\section{Worker's Remittances}

IMF's Balance of Payments Manual $6^{\text {th }}$ edition, defines remittances as "current private transfers from migrant workers resident in the host country for more than a year, irrespective of their immigration status, to recipients in their country of origin."

Remittances are one of the largest sources of external financing in many low-income countries. (World Bank 2006) They are also a relatively more stable form of funding than FDI, FPI and OFI (Buch and Kuckulenz 2004; Ratha 2003; World Bank, Challenges in Managing Capital Flows 2006)]. Despite their growing importance, very little empirical work exists on the impact of remittances on growth. Ratha (2003) makes the case that remittances are a very important source of development finance and observes that in countries with sound economic policies these remittances are often invested by the recipients. Another important feature of remittances is their countercyclical natureremittances are less volatile and fairly stable during economic downturns as compared to other forms of capital flows, including FDI (Ratha 2003; World Bank, Challenges in Managing Capital Flows 2006). In the recent economic downturn, remittances declined by $7.3 \%$, according to a recent report by the World Bank, this decrease have been far smaller as compared to the decline in other forms of private capital flows. (Migration and 
Development Brief 2008). Furthermore, in South Asia remittance flows have been especially resilient and continued to grow in 2009. Figure 7 shows the dramatic rise in remittances in LDCs in the last three decades.

Figure 7: Remittances in LDCs (Current US dollars)

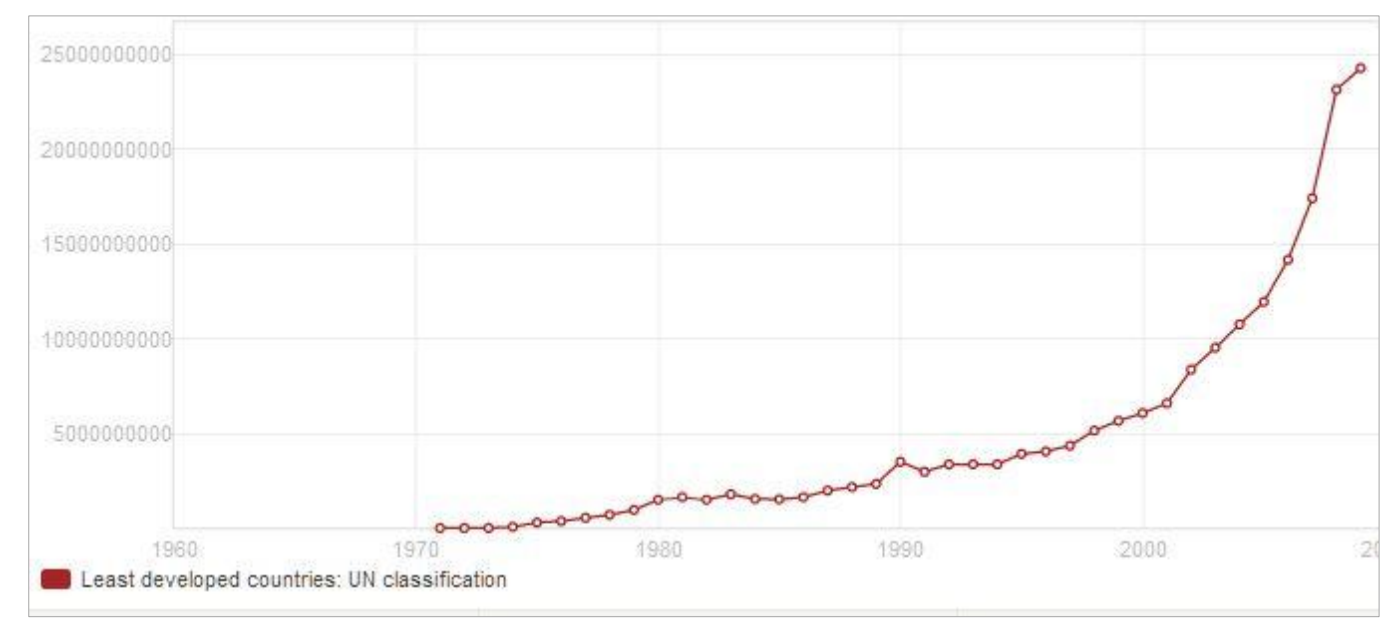

Source: World Bank, World Development indicators 2010:

http://data.worldbank.org/

This important source of development finance in poor countries, remittances have not received enough attention in the literature on financial globalization, which has mainly focused on FDI, FPI and loans. The nature of remittances is that of direct transfers and therefore expected to have a direct impact on the human welfare component of development. The current empirical literature on remittances, usually microeconomic analysis, draws on survey data of "migrant-worker and household behavior." (Buch, Kuckulenz and Manchec 2002: 9) 
Buch et al (2002) make the case that, if invested, remittances may have a positive impact on both the quality and quantity of investment. "Since migrants have a better understanding of local conditions than foreign creditors, remittances may help overcome asymmetric information and enforcement problems that typically beleaguer international capital markets." (2002: 8) Thus, the current study considers how well remittances fare in comparison to other forms of investments in poor countries, this aspect of the study is very important because there is a lack of empirical literature on the impact of remittances on the overall economic development.

\section{Official Development Assistance}

Foreign aid flows also known as Official Development Assistance (ODA) are an important source of external finance for most LDCs. Although ODA flows are not driven by market forces in contrast to the other forms of capital considered in this research, they are included in the LDC sample because of their relevance to less developed countries that are highly aid-dependent. Looking at ODA flows becomes even more important when investigating the causes of growth without development that is observed in several poor countries.

Despite being extensively explored in literature, there is a lack of robust findings on the universal effects of aid on economic development. Studies have reported findings all across the spectrum from a positive impact of aid on growth and development, to aid being detrimental to growth creating a destabilizing impact to institutions. Some have argued that "aid might be particularly associated with weak governance, possibly because 
aid inflows reduce the need for governments to tax the governed or enlist their cooperation." (Rajan and Subramanian 2007: 9) Similarly, a large number of studies have tried to investigate the aid and growth connection; however, there is no unanimous agreement in literature on the impact of aid on growth and very little research addresses the issue of whether aid flows improve human development.

\section{Political Performance}

The conceptualization of political performance of this study is based on Arbetman and Kugler (1997) and Arbetman-Rabinowitz, Kugler, Abdollahian, Kang, Tammen (forthcoming: chapter 1) who argue that "an effective government will achieve desired policy outcomes; a weak one will not. Political performance emulates in the political and institutional arena what GDP approximates in the economic field. Just as a rising GDP/per capita indicates financial success, political performance reflects policy success." They offer a three pronged approach to calculating political performance based on a government's ability to extract resources, mobilize its population and allocate resources to meet its objectives. The three components of political performance according to this approach are Relative Political Extraction (RPE), Relative Political Reach (RPR) and Relative Political Performance (RPA). RPE as a component of political performance measures a government's capacity to extract resources from the population and implement a given set of policies (Arbetman-Rabinowitz et al. forthcoming). RPR approximates the ability of the government to mobilize its population based on the labor participation in the formal sector of the economy. Finally, RPA measures the gap between actual expenditure and the optimal expenditures necessary for development. 
These measures of political performance are independent of regime type and offer a comparison of capabilities across nations at various points in time. The measures for RPE and RPR have been developed, while work on RPA is still in its infancy. Out of these three measures of political performance, RPE measures have been the most widely tested and have shown consistent results.

For the purpose of this dissertation, only the political extraction component is used as an indirect measure of political performance. There are several reasons for this, first, the empirical validity of the relationship between political extraction and political performance have been demonstrated in earlier works of Kugler and Organski (1980) and Arbetman and Kugler (1997). ${ }^{4}$ Secondly, the data for RPE has been tested and has produced reliable results. And finally, not much is known of the interactive effect between RPE, RPR and RPA. RPE offers a plausible assessment of political performance because policy implementation requires resources; efficient governments are expected to effectively extract resources to meet their policy goals where inefficient governments fail to do so. According to Arbetman-Rabinowitz et al. (forthcoming) "how much tax revenues a government can extract is a function of the level of economic development as well as the economic profile of the country" (forthcoming:14). Figure 5 incorporated from (Arbetman-Rabinowitz and Johnson forthcoming) depicts the political performance of governments at different levels of development and shows that efficient governments are better equipped to enact policy choices that impact economic and human development. This measure of political performance is a departure from the existing

\footnotetext{
${ }^{4}$ Early attempts in the literature to use taxing power of governments as a measure of capability are seen in Musgrave's (1983) work on "Who should Tax, Where and What?" as well as the work of Lotz and Morse (1967), Bahl (1971) and Organski and Kugler (1980).
} 
approaches in literature to measure the capabilities of national governments. Existing attempts to measure government performance are based either on democracy research or on quality of governance rather than a focus on a government's effectiveness in implementing policy goals.

Figure 8: Political Performance and Development

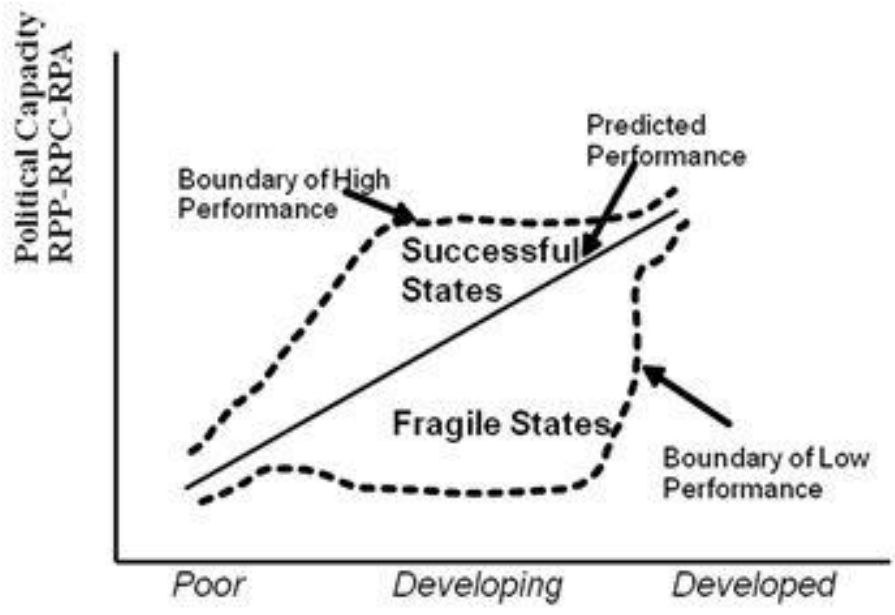

Source: Arbetman-Rabinowitz and Johnson forthcoming: chapter 3

In addition to relative political extraction as a measure of government performance, this dissertation also considered alternative measures prevalent in the literature on the political/institutional determinants of development. Two widely used sources are considered, viz. Heritage Foundation data on economic freedom and World Bank's World Governance Indicators. The merits of each are evaluated individually.

Heritage foundation provides an index of economic freedom in which they define economic freedom as "an absolute right of property ownership; fully realized freedoms of 
movement for labor, capital, and goods; and an absolute absence of coercion or constraint of economic liberty beyond the extent necessary for citizens to protect and maintain liberty itself." To this end, the heritage foundation data presents ten ${ }^{5}$ specific economic freedoms on a scale of 0 to 100 and the average of these ten freedoms form their measure of economic freedom. There are several limitations of these measures. First, as pointed out by Arbetman-Rabinowitz et al. (forthcoming), these measures of freedom reflect the policy choices of governments rather than capturing the ability of governments to make and implement choices. Secondly, these measures are strongly related to each other therefore their aggregation does not provide a unique understanding of the concept they aim to measure. And finally, as argued by Sala-i-Martin (1994), policy choices are so closely correlated with each other that data cannot tell them apart. For instance, "countries with high inflation rates tend to have distorted trade regimes and repressed financial sectors. They are also countries that are politically and socially unstable. None of the variables is a perfect measure of the phenomenon that matters; a government in disarray affects the nation's growth performance adversely." (Sala-i-Martin 1994) Thus none of these indicators actually measure the political performance and in fact are an imperfect measure of the same phenomenon.

The World Bank's Governance Indicators (WGI) corresponds to six major aspects of governance. Governance in this context is defined as traditions and institutions by which authority in a country is exercised (World Bank). The first measure in this regard is Voice and Accountability which gives the process by which the government is selected

\footnotetext{
${ }^{5}$ The ten components of economic freedom measured by Heritage Foundation are Business Freedom, Trade Freedom, Fiscal Freedom, Government Spending, Monetary Freedom, Investment Freedom, Financial Freedom, Property Rights, Freedom from Corruption and Labor Freedom
} 
and replaced and the participation of the citizens in the process. The next measure, Political Stability gives the likelihood of the government staying in power. Changes in government and its policies influence the quality of governance. Government Effectiveness is a measure of bureaucratic quality, competence of the officials and the independence of their dealings from political pressure. Regulatory Quality looks at the nature of the policies by examining the incidence of market-unfriendly polices in areas such as foreign trade and business development (Kaufmann, Kraay and Zoido-Labatón 2002). Rule of Law gives the extent to which people abide by the rules of the society and the fairness of these rules in regards to the sound working of the economic and social environment of the country. The last measure, Control of Corruption measures the perceptions of corruption in the country. The WGI have also attracted similar criticism as the Heritage Foundation measures; Langbein and Knack (2010) perform an empirical analysis of the WGI and conclude that these indicators are indeed reliable measures, but the phenomenon they measure is not entirely clear. These measures are further related to GDP per capita and not entirely distinct from each other which makes their validity as adequate measures of unique aspects of political performance problematic.

\section{Does Growth Mean Development?}

The element of interest in this study is to determine what brings about welfare in societies. The discipline of economics has tried to solve the problem of welfare of nations by the ubiquitous measure of growth in GDP per capita. Due to its simplicity, its wide acceptance as a reasonable measure of various dimensions of human welfare, as well as absence of a better alternative that proxy's human development, GDP per capita has been 
used as the standard measure of national development (Kelley 1991). Despite being widely used and accepted as a measure of development, GDP per capita has serious limitations because it fails to incorporate important dimensions of welfare such as health, education, etc. According to Acemoglu (2009), income differences between countries do have welfare consequences, however it does not imply that GDP per capita is a "sufficient statistic for the welfare of the average citizen" (2009: 8). It also ignores several other dimensions of development such as provision of certain kinds of freedoms to the society such as political freedom, economic facilities, social opportunities, transparency, and security (Sen 2001).

Efforts have been made to propose alternative measures of development, the most notable of which is Human Development Index (HDI) offered by United Nations Development Programme (UNDP) in its Human Development Report (HDR). HDI is a composite of life expectancy at birth, adult literacy, and real GDP per capita. Figure 4 below shows a ranking of countries by the HDI index and GDP per Capita. It is clear from Figure 10 below that there is a large disparity between the two measures. However, according to Kelley (1991), when HDI is compared to the log of GDP per Capita as shown in Figure 5, the observed disparity in Figure 4 vanishes and in fact GDP per Capita appears to provide a reasonable approximation for HDI (1991: 322). Thus, according to Kelley (1991) once the log transformation of GDP per capita is made, HDI makes very modest contribution in providing a new approach to development.

In addition to it being closely linked to GDP per capita, another limitation of HDI is that it is only available in five-year intervals; because of the nature of the data, it is illogical to extrapolate. 
Figure 9: Ranking of Countries by HDI and GDP per Capita

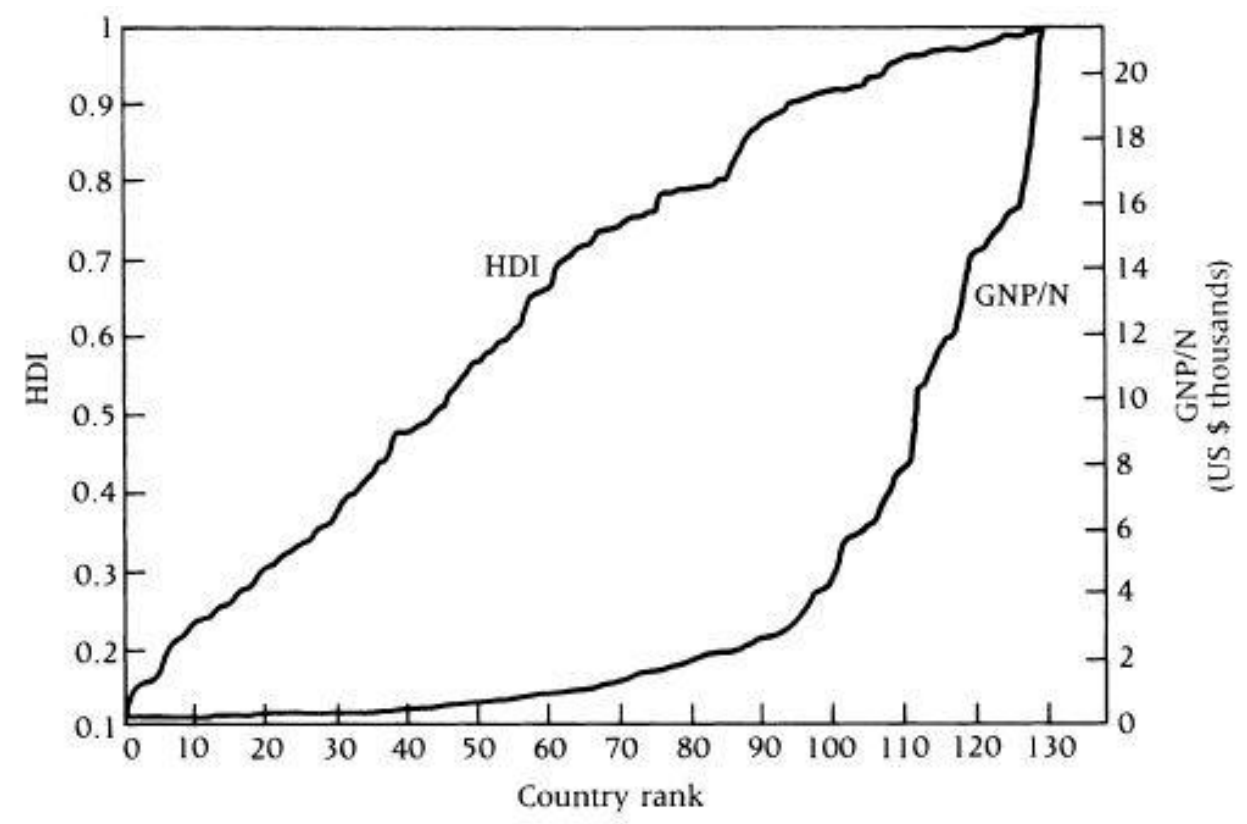

Figure 10: Ranking of Countries by HDI and log GDP per Capita

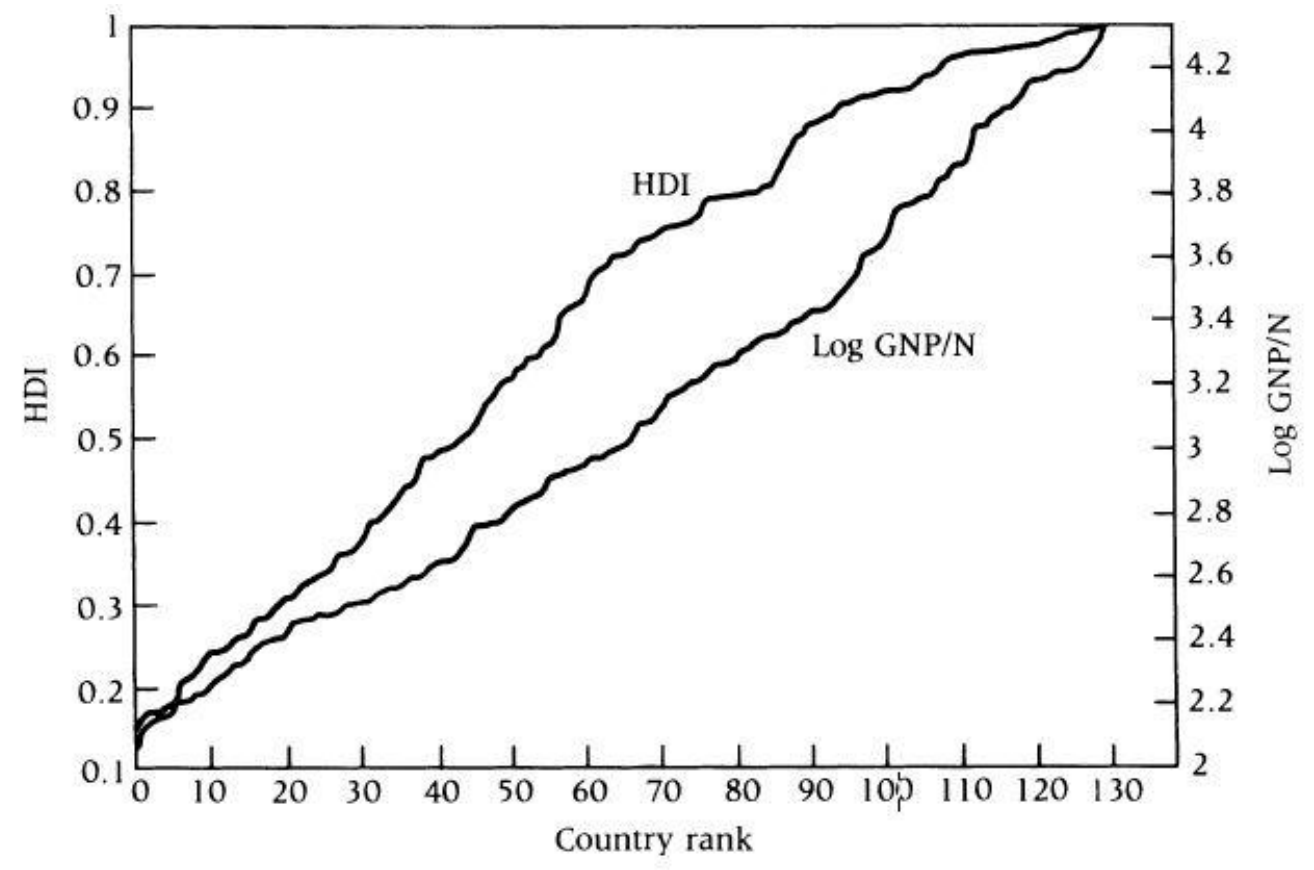

Source: A. C. Kelley 1991:321-323 
This study proposes to use Life Expectancy at birth as a better approximation of human development. Life Expectancy at birth indicates "the number of years a newborn infant would live if prevailing patterns of mortality at the time of birth were to stay the same throughout its life." (World Bank 2010: http://data.worldbank.org/) Several important reasons motivate the use of life expectancy as a measure of development. First, Life Expectancy at birth forms the health component in the calculation of HDI; second, it provides an empirically practical way to measure development that is different from GDP per capita. Life Expectancy as a measure of development is also found in the work of Lutz (1995), who argues that it is a fundamental measure of social development because it reflects the distributional effects of wealth. Using the Life Expectancy based measures developed by Lutz (1995), other have argued that "inequalities are expressed not only in terms of income but also in terms of the allocation of social services, being poor leads to a shorter life because the individual is not able to meet the basic needs of food, health, and shelter." Along the same lines, Arbetman-Rabinowitz and Johnson (forthcoming) argue that measures that reflect the extent to which the needs of a population are being met are a better proxy for the quality of life of the population over wealth based assessments of poverty.

The following section reviews the neo-classical theory of economic growth as well as the state of existing empirical literature on the capital flows, politics, and development connection. 


\section{Theories of Economic Growth: Solow Model}

One of the most influential works in neoclassical economic growth theory is the growth model developed by Robert Solow (1956). A very important implication of the Solow Model is the "convergence hypothesis," i.e. economies ultimately converge to their steady state income levels. This implies that countries at low levels of development should have higher growth rates than countries at higher levels of development because they are further away from their steady state. The Solow Model contested the findings of the Harrod-Domar Model and instead proposed a model where the capital-output ratio would bring an economy back on its path to steady state growth.

As data started to become available in 1980s and 1990s, there was resurgence in literature on economic growth which could now benefit from empirically studying what neoclassical literature of the 1960s had theorized. The empirical literature utilized crosssection analysis, time-series data and case studies and more recently panel data methods. Early empirical literature failed to find evidence on convergence and led theorists to question the neo-classical model. However, Barro and Sala-i-Martin (1992) and Mankiw, Romer, and Weil (1992) argued that neoclassical model did not predict that poor countries would grow faster but rather predicted that "the growth rate of an economy was inversely related to the distance from its steady state." (Sala-i-Martin 1994) Only if all economies converged to the same steady state, despite their differences is technologies, savings, taxation etc., would poor countries grow faster. This concept of convergence conditional on the steady state is termed "conditional convergence." Later studies by Barro (1991), Barro and Sala-i-Martin (1992) etc. maintaining the basic framework of Solow Model added some explanatory variables which formed the baseline for much of 
the empirical work in growth economics. Because of Barro's extensive use of crosscountry growth regressions to study growth determinants, cross-country regressions are also referred to as "Barro Regressions." (Durlauf, Johnson and Temple 2004) The next section discusses the state of the existing empirical literature on the determinants growth and development.

\section{Limitations of the Existing Research on Capital Flows, Politics and Development}

Existing empirical literature in the capital flows and development connection is deficient and inconclusive in fundamental ways. A large number of studies that explore the impact of capital flows on development either use aggregate measures for capital flows or are mainly focused on the FDI and growth connection. (Kyaw and MacDonald 2009) The studies that aim to explore the developmental impact of FDI do not have conclusive results. None of these address whether or not the capital flows prompted growth in GDP per capita translates into human development.

Neo-classical theorists have long argued that influx of foreign capital have very important developmental implications for capital starved poor countries. According to the neoclassical growth models, such as the Solow Model noted above, poor countries that are scarce in capital would have a higher marginal productivity of capital implying higher returns on investments. These theories have assumed that capital would therefore flow from rich developed countries to poor developing countries and therefore bring about the economic transformation of weak economies that would not otherwise be possible. (deSoysa 2003) 
Empirical studies on the capital flows and economic growth connection show mixed results; the impact of capital flows on development (measured differently from growth) remains almost entirely undocumented. Some have argued that these ambiguous results are due to inaccurate pooling of developed and developing countries in the same sample (Blonigen and Wang 2005) while others argue that the mixed results are due to aggregating capital flows and failure to break up capital flows into various categories by income. (Kyaw and MacDonald 2009)

Traditional neoclassical economics literature has looked at growth of GDP per capita as a proxy for the rate of development. However, as noted above, "strategies solely to boost overall growth may miss opportunities to reduce poverty more effectively.” (World Bank Annual Review of Development Effectiveness 2006) The question of whether increase in growth brings about development is one that is becoming exceedingly important to answer, especially as the critics of globalization continue to point out that "globalization might be creating rich countries with poor people." (Stiglitz 2006: 9). Very little empirical work exists on the developmental impacts of other forms of capital flows such as portfolio flows, bank lending, remittances etc. And finally, the role of politics is primarily left out in the literature on the link between capital flows and development. Some notable empirical studies in the economics literature are as follows.

\section{Empirical Approaches to Capital Flows Development}

Prasad et al. (2007) empirically explore the question of whether foreign capital plays a "helpful, benign, or malign role in economic growth." (2007: 153)Their study uses current account balance as a composite measure of capital flows, because from a 
financing perspective, they argue, all forms of capital are relevant for determining the impact on growth (2007: 157-158). According to the authors, "financial underdevelopment and underdevelopment more generally, could exacerbate foreign capital's contribution to a rise in costs in the non-traded sector, and to overvaluation." Prasad et al. (2007) Their findings suggest that poor countries have little ability to absorb the financial capital, and in some cases rapid inflow of capital may lead to the overvaluation of the domestic currency. Other detrimental aspects of foreign capital can include increasing economic volatility because of the reversible nature of some capital flows. One problem with the analysis of Prasad et al. (2007) is their treatment of capital flows as a single aggregate measure rather than examining the impact of various capital flows separately.

Many studies have argued that the composition of capital flows indeed matters when evaluating the impact on growth as well as the issue of currency crisis (Eichengreen 2004; Henry 2006; World Bank 2006; Tong and Wei 2009). A detailed analysis on the issue of capital flows and crisis is found in the work of Eichengreen (2004), who argues that although foreign finance can contribute positively by augmenting domestic resources and transferring technology, the "magnitude of these benefits is disputed, and none of them is guaranteed, especially if capital movements set the stage for costly crisis" (2004: 4). Although the current study does not directly explore the issue of currency crisis, it motivates the consideration of multiple sources of capital when exploring the growth and finance connection.

Tong and Wei (2009) examine the link between foreign capital and crisis by exploring whether "the pre-crisis volume and composition of capital inflows 
systematically affect the severity of the credit crunch across countries." (2009: 4) Their analysis on the 2007-2009 crisis shows that it has a direct correlation to the severity of the impact that a credit crunch creates. Their findings suggest that although the volume of pre-crisis capital flows is not systematically related to the severity of the credit-crunch, the composition of the flows definitely matters. They find that large pre-crisis exposure to non-FDI flows is related to the severity of the credit-crunch. This lends support to the argument that "different types of capital flows bring different benefits and costs to recipient countries." (2009: 5) This also serves as a rationalization for the current study to use different types of capital flows in determining the welfare effect of flows, if any, on the host countries.

There is a growing body of empirical literature in economics discussing the impact of FDI on growth; however the literature is not developed on the theoretical front. The most notable contributions to the relevant literature are summarized below.

Moran, Graham and Blomström (2005) conduct an analysis to answer to the question, “How does FDI impact economic development?" Their study specifically investigates whether it is a good policy for developing countries to allocate scarce resources to create conditions that would attract FDI. They point to the importance of positive externalities and spillovers as an important issue in answering this question. Consequently, they offer new approaches to measure the positive spillovers from multinational activity, which are very difficult to quantify but nevertheless very essential for the host countries. Görg and Strobl (2005) however argue that the traditional characterization of spillovers is too restrictive and therefore provide a methodology that 
evaluates spillovers that result in improved profitability of the domestic firms within host countries.

Lipsey and Sjöholm (2005) analyzed why past studies have come to such varying conclusions on the impact of FDI on domestic economies. They analyzed a series of causes starting from differences in techniques, and difficulties in quantifying spillovers; they attribute the variance in results to the differences in abilities of the countries to benefit from FDI. These differences according to their analysis are a result of factors such as policies, levels of domestic competition, private-sector sophistication etc. Thus, they conclude, that a quest for universal effects of FDI on development is futile as the results vary based on host country attributes. This also indicates the importance of using a variable of political performance in the current study and expanding the analysis to a broad range of capital flows to determine what type of flows are best suited given the capacity of institutions.

In another study, using data collected from Indonesia, Blalock and Gertler (2005) find that presence of externalities result in economic returns to host countries which exceed the private returns to multinational investors. The reason for this finding according to the authors is due to technology transfers, which lead to "lower prices, increased output, higher profitability and increased entry in the supplier market." (2005:73) A big factor in technology transfers, based on evidence from a series of interviews carried out in Indonesia, is the stringent requirements of the United States and Japanese firms regarding quality control, design control and inventory control. Meeting these standards requires educating the local managers in the multinational corporation's quality assurance procedures. 
Asim Erdilek (2005) compares the R\&D (research and development) activities of multinationals versus the domestic firms using evidence from Turkey. His findings show that foreign firms with high levels of external ownership and lower propensity to engage in $R \& D$ as compared to foreign firms with low levels of external ownership. This finding is contrary to the view that multinationals are more likely to share technologies with their wholly or majority owned subsidiaries as compared to less controlled companies.

Carkovic and Levine (2005) investigate the relationship between FDI and growth and conclude that FDI does not accelerate growth as a general proposition. However factors that do contribute to growth, as well as FDI, according to this analysis, are the sound economic policies of the host country. Blonigen and Wang (2005) disagree with this finding. They bring up a point, usually unnoticed in cross-country empirical analysis involving FDI. A method that pools developed countries and developing countries together is based on the false premise that the impact of FDI is similar for developed and developing countries. The data shows that in reality it is the opposite. According to Blonigen and Wang (2005), the results change quite a bit when data of the rich and poor countries is pooled separately. A main reason for the difference in results is that countries at different levels of development differ in their absorptive capacity of capital. Some have argued that this difference in absorptive capacity can hinder the growth-inducing impact of capital flows (Lucas 1990). As a result, estimation that pools all the countries together is a faulty method and leads to misleading conclusions. Similarly, it is also misleading to pool emerging market countries that have had high economic growth rates with lowincome non-industrial non-transition countries. This argument necessitates splitting the 
data into categories of Developed Countries, Emerging Markets, and Less Developed Countries in this dissertation.

Egger and Winner (2006) also find a difference in FDI flows to OECD economies as compared to non-OECD economies; lending further validity to the Blonigen and Wang (2005) argument. In addition, Akcay (2001) in his study on developing economies finds that country characteristics such as education level, infrastructure etc. play an important role in determining the net impact of FDI flows.

Globerman and Shapiro (2002), specifically look at the government infrastructure of a country in terms of political, economic, and legal institutions that makes it a recipient of United States FDI. Their findings suggest that improvement of government infrastructure increases the country's probability of receiving greater FDI flows highlighting the importance of political reform in order to stimulate economic growth in LDCs. Various other factors in the literature linked to attracting FDI are transaction freedom, market size, exchange rate regimes, a legal system that follows English Common Law and a legislation that effectively protects property rights (Globerman and Shapiro 2002; Kaufmann et al. 2002).

\section{Political Economy Approaches to Capital Flows and Development}

While a substantial amount of empirical literature supports the claim that foreign capital promotes development, a comparable amount of literature demonstrates a negative relationship between foreign capital and development (Kehl 2008). An influential body of literature in Sociology and Political Science sees the structural power of international capital as exploitive and harmful to developing countries (deSoysa 2003) . Dependency 
theorists have argued that the foreign investment from the Multinational Corporations (MNC) in core countries to the developing nations is harmful to their long term economic growth. In this tradition the work of Bornschier (1980), Dos Santos (1970); and Bornschier and Chase-Dunn (1985) is notable. Bornschier's (1980) empirical analysis finds that "MNC-penetration is negatively related to subsequent investment growth"; the author uses this finding to lend credence to the "decapitalization thesis" which argues that MNCs have long- term negative effect on income growth. Bornschier and Chase-Dunn (1985) support this finding by arguing that MNC penetration systematically underdevelops host countries economically, socially, and politically. According to this view, FDI may cause an initial increase in growth, however, "peripheral countries that adopt this path of unequal development based on income equality and foreign capital imports will experience economic stagnation." (Bornschier and Chase-Dunn 1985:39) The results of this influential study in the dependency tradition were later disputed by Firebaugh (1992), whose reanalysis showed a methodological flaw in the analysis of Bornschier and Chase-Dunn (1985). (deSoysa 2003)

Other dependency theorists such as Dos Santos (1970) view underdevelopment as a consequence of the world expansion of capitalism, and focus on a new postwar form of dependence called "technological-industrial dependence" instigated by multinational corporations. This form of dependence places structural limits on the development of the third world economies by creating deficits. Dos Santos (1970) argues that, "foreign capital retains control over the most dynamic sectors of the economy and repatriates a high volume of profit; consequently capital accounts are highly unfavorable to dependent countries." (1970:233) As a result, the dependent economies get trapped in a vicious 
circle where they become dependent on the foreign sources of finance to fill the holes that were created by foreign capital in the first place (DosSantos 1970).

The claims of dependency theory were contested by scholars such as Hein (1992). Instead the focus turned to the important role of state and policies in the process of development. Hein's (1992) analysis did not find support for the dependency theory and instead found growth to be dependent on factors such as region, policy, population and the political stability. Furthermore, Hein's (1992) findings show that state policies affect economic growth as seen in the case of Asia and Latin America, where official economic policies were relevant factors in the explanation of foreign investment and economic growth connection. Hein (1992) argues that "the dependency approach to development may be applicable to specific regions of the world at certain historical periods, but its ability to generalize to other cases is limited." (Hein 1992:496) Later dependency theorists such as Dixon and Boswell (1996) made the case that domestic investments are more growth-inducing than FDI. This further encourages the inclusion of domestic sources of capital in the current study. Others dependency scholars such as Kay and Gwynne (2000) linked the financial vulnerability to dependency, specifically in the context of the financial crisis in Latin America and East Asia.

Kehl (2008) argues that one of the reasons for such contradictory themes in regards to the role of international capital development is due to the central problem that "foreign investors and domestic host governments have divergent interests: foreign investors are interested in maximizing profits, governments of host countries are, presumably, interested in promoting domestic growth" (Kehl 2008). Primarily focusing on FDI as a measure of foreign capital, Kehl (2008) makes the case that the benefits of 
foreign investment on domestic development are in fact contingent on the interaction of "foreign investment with democratic institutions and government effectiveness". Thus, according to this analyst, prior research focuses on how to attract foreign investment rather than how to utilize it and she argues that "democratic development and effective policy-making institutions can increase the capacity of governments to utilize foreign investment to promote domestic economic growth." A major drawback of this research is that it primarily focuses on FDI, thus ignoring the relative importance of other forms of capital, including domestic resources. Furthermore, for analyzing the role of politics, Kehl (2008) uses measures of democracy from Polity IV dataset; and for government effectiveness she uses the widely criticized world governance indicators. The next section further explores the notable attempts to explore the political determinants of development.

\section{Politics and Development}

Most attempts to look at the role of politics in the process of development are based on democracy research. Much of this research on the democracy and financial globalization connection, however, has ambiguous results. Eichengreen and Leblang (2006) support the idea that, "there are causal connections between globalization and democracy is intuitively appealing." (2006:6). Various studies have reported findings such as democracies remove capital controls and thus contribute to financial openness. (Brune and Guisinger 2003; Quinn 2000) Others find similar positive relationship between democracy and trade openness (Lopez-Cordova and Meissner 2005; Yu 2005) However, the approaches employed by these studies have been criticized on 
methodological grounds. (Barro 1998; Eichengreen and Leblang 2008) Similarly, many studies have explored the connection between democracy and development, yet the evidence has been inconclusive. This study further formalizes the role of politics in the process of development by using a measures of political performance based on the work of Arbetman and Kugler (1997) and Arbetman et al. (forthcoming).

Barro (1996) in a widely quoted empirical study makes the case that studies which show a positive relationship between democracy and growth, do so only because they do not account for human capital. He argues that there is no link between regime type and economic growth, and once human capital is controlled for, the positive relationship between growth and democracy vanishes. This inconsistency in findings has led some to argue that it is not the regime type but rather the quality of institutional arrangements that affects economic development. (North 1989) According to Przeworski and Limongi (1993), "political institutions do matter for growth, but thinking in terms of regimes does not seem to capture the relative differences" (in de Soysa 2003:75). The proponents of this view argue that the quality of economic and political institutions is a major determinant of economic performance. (North 1990; Acemoglu, Johnson and Robinson 2001; Bardhan 2004; Rodrik, Subramanian and Trebbi 2004) Another perspective on development argues that "patterns of development are shaped by an exogenously given natural environment, 'geography'.” (Przerworski 2004). In this perspective, there are several ways in which geography, climate and ecology can impact a nation's prosperity. According to this approach climate can impact work effort, incentives, productivity as well as technology available to society (Acemoglu et al. 2001). Geographical location may also be linked to poverty by affecting the disease 
burden of a society (Sachs 2000). For the purpose of this study, political extraction is the variable of interest to incorporate the role of politics in the process of development.

The above review shows that the literature on capital flows and development has ambiguous findings and is disjointed between the various perspectives within economics, sociology and political science. Empirical research on the capital flows and development nexus mainly focuses on FDI flows or aggregate capital flows rather than evaluating the developmental impact of each form of capital flow separately. And finally most studies almost entirely disregard the role of politics in the process of development.

The current research tackles these issues from a comprehensive and much-needed perspective that draws upon these multiple disciplines because as put by one scholar, "in no other field of social sciences are politics and economics so closely intertwined as in the study of development." (Bates 1988 in de Soysa 2003) And yet, influential economic literature on development ignores the research in political science while the notable studies in other social sciences downplay the important contribution of the economics literature in understanding the issues around growth and development. 


\section{Chapter - 3}

\section{Model of Analysis}

The purpose of this chapter is to propose a model that looks at the impact of capital flows on economic development and growth. Although conflicting views in the literature exist on the finance and growth relationship, this study aims to revisit the relationship between capital flows and development in the light of political factors. Several methodologies in the literature have been employed to investigate whether foreign capital plays a role in economic development and growth. This study is related to the paper by Prasad et al. (2007) that explores the links between foreign capital measured by current account balance, and economic growth, but differs from them on several fronts. Firstly, in addition to using an aggregate measure of capital flows, like the current account balance, this study looks separately at each of the main foreign capital flows, i.e. foreign direct investment, portfolio flows, and other financial investments. Furthermore, due to the growing importance of remittances as a significant source of capital, this study analyzes the developmental impact of remittances. Finally, foreign capital alongside, domestic sources of capital are considered.

Other distinguishing aspect of this research includes looking at the economic as well as the political determinants of development. Although a growing body of literature on the impact of political institutions on growth exists in political science and sociology, 
it does not provide adequate treatment to the economic determinants of growth. Some of the most prominent studies, even in the field of developmental economics, simply ignore finance (Levine 1997). Similarly, a lot of the growth and development literature in economics downplays the importance of political factors. To overcome this gap, this study looks at RPE as a measure of political performance. As already explained in Chapter 2, not much is known of interactive relationship RPE, RPR and RPA, whereas RPE measures have been empirically tested and shown to be reliable. Therefore political extraction offers a valid assessment of political performance that focuses on the ability of a government to extract resources to implement a given set of policies.

This research finds that not all capital flows are created equal; hence, different capital flows will produce varying developmental impacts given the developmental level and the political performance of a country. The related paper by Prasad et al. (2007) argues that in non-industrialized developing economies foreign capital (measured by their composite indicator) does not contribute to economic growth - however their analysis on FDI flows shows them to be growth inducing. In fact, in a country that lacks the absorptive capacity due to weak political and institutional structures, inflow of external finance is directly correlated to the overvaluation of currency causing the Dutch disease.

For their analysis, Prasad et al. (2007) use current account balance which is the difference between a country's saving and investment, as a measure of "net capital, including private and official capital, flowing in or out of the country." (2007:154) The authors further observe that capital does not seem to flow from rich countries to poor countries as text book theories suggest, but rather the reverse pattern seems to hold, a phenomenon called the "Lucas Paradox." The authors choose current account balance as 
their variable of choice because it is a composite measure of all the capital that leaves the country minus all capital coming into a country. Then they evaluate whether foreign capital contributes to development by augmenting domestic resources. Their conclusions find that countries with poorly developed financial markets are unable to reap the benefits of external capital, and in a poor institutional setting, external capital may do more damage than good.

The authors pose some interesting questions; however, a problem with their analysis is the use of a composite measure of current account balance to analyze the impact of foreign capital. Different forms of capital flows have different developmental impacts on the economy which makes the use of composite measures problematic. As the authors' note in their analysis, the capital flows and growth pattern does not hold for FDI, where FDI and portfolio flows form $45 \%$ of total capital inflows to developing countries ${ }^{6}$. According to the authors, fast growing countries do utilize FDI, but they do not utilize more capital overall. Another drawback of the Prasad et al. (2007) study is the classification of their country sample. They lump most of the emerging market countries in their non-industrial, non-transition country sample. Given the success of the emerging markets in recent years, such a classification is misleading and does not provide a path of progress to poor countries trying to move along the scale of development.

This study isolates the various forms of capital flows to study their developmental impacts on a country's economy. For this purpose, the study uses the basic components of capital flows, viz., foreign direct investment, portfolio investments, other investments, and remittances. Domestic sources of capital in the form of domestic savings are also

\footnotetext{
${ }^{6}$ (Henry 2006)
} 
considered, since Prasad et al (2007) posit that, it is the weak institutional structure and not the lack of savings, which is the primary obstacle to growth in poor countries. Another motivating factor for using domestic savings in the analysis is that the textbook theory does not differentiate between domestic and foreign sources of financing. Therefore, this study looks at domestic sources of finance to consider whether domestic capital is more efficient than foreign capital in countries at low levels of political performance. Another justification for the inclusion of domestic capital is to test the claim that domestic agents have an advantage over foreign agents in overcoming the obstacles of corruption, weak institutions, and infra-structure issues. (Aizenman and Spiegel 2004)

Finally, in addition to considering the above mentioned sources of foreign capital this study also looks at the role of remittances on economic development. Recent trends show that remittances have become increasingly important for the economic development of poor countries. Some studies have shown that remittances are the second most important source of external capital after FDI, in developing countries. (Ratha 2003) In addition to becoming an important source of external financing, remittances are also a stable source of funding in comparison to FDI (Buch and Kuckulenz 2004; Ratha 2003; World Bank 2010). Despite their importance, the literature on the linkages between remittances and economic growth is still in its infancy. In Latin America, remittances are becoming increasingly important and according to one source,

[Remittances] are considerably more important than official development assistance (ODA) and equal the foreign direct investment (FDI) volume for the region. In some of the poorest countries of the hemisphere (Haiti, Guyana and Honduras, to name a few) they account for more than $10 \%$ of the GDP, and, in several Latin American countries, remittances per capita readings are higher than 
the GDP per capita of the poorest $40 \%$ of the population." (Blossier 2010: http://www.coha.org/migradollars-and-economic-development/)

Despite these benefits, remittances can also have negative impacts such as contributing to Dutch disease (Ratha 2003). Thus evaluating the impact of various forms of capital given the development level of the economy is essential, as different flows may bring about varying impacts. The other contribution of this study is to show that the determinants of growth and development are not the same; hence the study tests two models for economic growth and economic development. The study aims to evaluate if the factors that influence growth also bring about development, and what factors explain the cases of growth without development.

\section{Theoretical Framework}

This section looks at the conceptual framework which motivates the estimating equations. The element of interest in this study is to look at the determinants of growth as well as the determinants of development. In the first part of the analysis, the goal is to specify a statistical model of cross country growth regressions that looks at various determinants of growth including initial conditions. Much of the empirical work on growth uses the Solow Model as a baseline for the analysis. Keeping in line with the literature on economic growth, a standard production function of the following form is considered: 
(1) $\quad Y=F(K, L, F, t)$

where,

$\mathrm{Y}=$ Real Gross Domestic Product

$\mathrm{K}=$ Domestic Capital Stock

$\mathrm{L}=$ Labour Inputs

$\mathrm{F}=$ Foreign Capital Stock

$\mathrm{t}=$ time

Using the basic Solow framework, cross country growth regressions can be derived as shown in the work of Barro (1991). Based on the work of Durlauf et al. (2004), Balasubramanyam, Salisu and Sapsford (1996), and Barro and Sala-i-Martin (1995), this study uses the following cross-country regression.

$$
\gamma_{c t}=\beta y_{c t-1}+\psi X_{c t}+\pi Z_{c t}+\varepsilon_{c t}
$$

where $\gamma_{c t}$ denotes the overall growth in country $c$ at time $t . \beta, \psi$, and $\pi$ are the output elasticities; $X_{c t}$ and $y_{c t-1}$ define the variables that are a part of the Solow Model as shown in (1) and $Z_{c t}$ are the determinants of growth that are outside the Solow model. For the purpose of this study, the standard equation presented in equation (2) is applied to panel data analysis. The following equation specifies the variables $X_{c t}$ and $Z_{c t}$ that are employed in this analysis.

The issues around proposing a model of development are more complex. For this dissertation, the motivating model for testing the determinants of development is based on Arbetman and Johnson (forthcoming) who using infant mortality as a measure of 
human development in a sample of 53 African countries, explore the economic and political foundations of human development. Their model considers human development as a function of foreign capital inflows (using FDI flows and foreign Aid), political performance, and demographic factors. ${ }^{7}$ While their study is limited to the oil and non-oil producing countries of Africa, this dissertation extends their proposed model to a larger group of LDCs and considers all available forms of capital (foreign and domestic) to explore the underpinnings of development.

\section{Estimating Equations}

The models that this study estimates are of the following form:

Growth $=F($ economic factors, political performance $)$ Development $=F($ economic factors, political performance $)$

Thus the estimation strategy is to run regressions of the following form:

$$
\begin{aligned}
\text { Growth }_{c t} & =\alpha+\beta_{0} \text { IntialGDPcapita }_{c t}+\beta_{1} \text { DomesticSavings }_{c t} / G D P_{c t} \\
& +\beta_{2} \text { ForeignCapital }_{c t} / G D P_{c t}+\beta_{3} \text { CurrentAccountBalance }_{c t} / G D P_{c t} \\
& +\beta_{4} \text { RPE }_{c t}+\beta_{5} \text { WorkingPopulation }_{c t}+\beta_{6} \text { Controls }_{c t}+\varepsilon_{c t}
\end{aligned}
$$

\footnotetext{
${ }^{7}$ Arbetman and Johnson(2009) test the following model:

InfantMortality $=$ PoliticalPerformance + FDIInflows + ForeignAid + OilProduction + Year + error
} 
And for looking at the determinants of development in LDCs, the following equation is employed:

$$
\begin{aligned}
& \text { Development }_{c t}=\alpha+\beta_{0} \text { DomesticSavings }_{c t} / G D P_{c t}+\beta_{2} \text { ForeignCapital }_{c t} / G D P_{c t} \\
& +\beta_{3} \text { CurrentAccountBalance } e_{c t} / G D P_{c t}+\beta_{4} R P E_{c t} \\
& +\beta_{5} \text { WorkingPopulation }_{c t}+\beta_{6} \text { Controls }_{c t}+\varepsilon_{c t}
\end{aligned}
$$

The results are reported using four specifications, across disaggregated samples of the dataset in various dimensions; the countries are divided, using GDP per capita as criteria, into the developed and less developed country samples. Given the extraordinary performance of emerging markets, a separate category for emerging markets is included in the analysis, where the list of countries in the emerging markets is based on the Standard and Poor's (S\&P) classification. The motivation for reporting the results by these varied specifications can be found in various studies on foreign capital and growth, which argue that one reason for the inconclusive evidence in literature is due to inaccurate pooling of developing and developed countries into the same sample. (Blonigen and Wang 2004) The other consideration behind this pooling is to isolate the detriments of growth and development and provide some insight into how nations at lowlevels of development can move up the scale of development to join the ranks of emerging markets and finally that of high-income countries. 


\section{Variables and Data}

This section describes all the variables that are a part of the empirical model. The data is collected for 120 countries from 1980-2007. The findings are further reported for sub-samples of developed countries, emerging markets and less-developed countries. This study utilizes a composite measure of capital as well as disaggregated capital flows. Most of the capital flows data is in current US dollars. Because current series are influenced by inflation, the financial data is presented as a ratio to GDP. The following variables are considered for this study.

$C A-G D P$ : Current Account balance as a percentage of GDP is used as a composite measure of foreign capital, consistent with Prasad et al (2007). Current account balance,

according to WDI database, "is the sum of net exports of goods, services, net income, and net current transfers." (World Bank 2010: http://data.worldbank.org/) The data on current account comes from the IFS CD-ROM (2010) as well as from World Bank's World Development Indicators (WDI) database (2010). Both data are comparable and the more complete series is utilized.

FDI/GDP: Foreign Direct Investment flows in current US dollar data also comes from the IFS CD-ROM (2010) as well as from World Bank's WDI database (2010). This series shows net inflows (new investment inflows less disinvestment) in the reporting economy from foreign investors. Because the data is in current US dollars, it is presented as a ratio to GDP. 
FPI/GDP: Foreign Portfolio Investment refers to "non-FDI cross-border investment in equity and debt securities."(IMF Balance of payments and international investment position manual 2009:110) Data on FPI in also in current US dollar and is taken from the IFS CD-ROM (2010) as well as from World Bank's WDI database (2010). FPI flows are also presented as a ratio to GDP

OFI: Other Foreign Investments data which includes bank loans and trade-related lending is in current US dollars and is retrieved from the IFS CD-ROM (2010) and is presented as a ratio to GDP.

Remit/GDP: Data on workers' remittances data in current US dollars is taken from the World Bank's WDI database (2010) and is presented as a ratio to GDP.

Save/GDP: Domestic Savings is used as a proxy for domestic resources for the purpose of this study. Savings here is "equal to gross national savings less the value of consumption of fixed capital" (World Bank 2010: http://data.worldbank.org/). The motivation for using domestic savings as a proxy of domestic capital comes from Prasad et al. (2007). This data is in current US dollars and is taken from the World Bank's WDI database (2010) and is presented as a ratio to GDP.

$O D A / G D P$ : For the LDC category, aid data is used in addition to the other financial flows. The use of foreign aid in the LDC sample is motivated by Arbetman and Johnson. (forthcoming) The data on aid or net official development assistance is taken from World 
Bank's WDI (2010) and “consists of disbursements of loans made on concessional terms (net of repayments of principal) and grants" (World Bank 2010:

http://data.worldbank.org/). This data is in current US dollars and is presented as a ratio to GDP.

Work: Measure for size of the working population as a ratio to total population is extracted from WDI (2010) database.

Second: Secondary education data is taken from WDI database and provides the ratio of total enrollment, regardless of age, to the population. According to the World Bank, "secondary education completes the provision of basic education that began at the primary level, and aims at laying the foundations for lifelong learning and human development, by offering more subject- or skill-oriented instruction using more specialized teachers." (World Bank 2010: http://data.worldbank.org/).

RPE: The political performance variable (RPE) is based on Arbetman and Kugler. (1997) Relative political extraction measure gives the capacity of a government to extract resources from its population. Based on the work of Arbetman and Kugler, (1997) and Arbetman-Rabinowitz et al. (forthcoming), RPE is calculated as follows:

$$
R P E=\frac{\text { Actual Tax }}{\text { Predicted Tax }}{ }^{8}
$$

\footnotetext{
${ }^{8}$ Arbetman and Kugler (1997) employ the following models for calculating RPE:

Tax $/ G D P=\beta_{0}+\beta_{1}$ time $+\beta_{2}$ Mining $/ G D P+\beta_{3}$ Agriculture $/ G D P+\beta_{4}$ Exports $/ G D P$

$+\beta_{5}$ CrudeOilExports / TotalExports $+\varepsilon_{c t}$
} 
Several other measures of political performance exist in the literature such as measures of democracy, corruption, governance indicators etc. This study uses Relative Political Extraction (RPE) as a measure of political performance. An important benefit of using RPE as a measure of performance is that it is independent of regime type. A detailed treatment of the RPE measure is found in Arbetman and Kugler, (1997).

GDP per Capita: This is "gross domestic product divided by midyear population" (WDI 2010).This data is taken from World Bank's, World Development Indicators. Data are in constant 2000 US dollars. The data on GDP (gross domestic product) is extracted from the WDI database.

\section{Dependent Variable}

Growth/Gy: The data on Growth of GDP per capita is taken from the World Development Indicators (WDI) and gives annual percentage growth rate of GDP per capita based on constant local currency. The growth data is also cross-referenced by calculating annual growth rates by the formulae provided below. For Panel Data by country Gy is calculated as:

$$
\mathrm{Gy}=\ln [\mathrm{Y}(t)-\mathrm{Y}(t-1)]
$$

The growth rates used in cross-sectional analysis are also calculated by using the formula below.

For Cross Section:

$$
\mathrm{Gy}=\ln [(\mathrm{Yt})-\mathrm{Y}(0)] / \mathrm{t}
$$


where, $y$ is the GDP per capita measured in constant 2000 US dollars and Gy is the growth rate calculated by the formulae above.

In addition to Growth, this analysis also looks at whether and how different forms of foreign capital contribute to the social/human development aspects of poor countries. Several attempts are present in the literature to measure human development, most notable is HDI. However, HDI data is only available in five-year intervals and it does not monitor progress in the short-term - it takes time before policy interventions reflect on HDI indicators. To overcome this, this analysis uses life expectancy at birth, to measure of the rate of development as an alternative to GDP per capita.

Life Expectancy: Life expectancy at birth data "indicates the number of years a newborn infant would live if prevailing patterns of mortality at the time of its birth were to stay the same throughout its life" (World Bank 2010: http://data.worldbank.org/). A similar measure to capture human development has been used in the work of Lutz (1995).

Table 2 provides the summary statistics for the variables considered for this analysis. However, as noted above, countries at different phases in their development, differ in their ability to utilize investments for growth and may also vary in the relative importance of economic, political or demographic factors for development. To provide a snapshot of the differences in the country samples, the next section briefly discuses the choice of samples by levels of development and presents summary statistics in each category. A complete listing of countries used in this study is presented in Appendix A. 
Table 2. Summary Statistics for the Whole Sample

\begin{tabular}{llllll}
\hline Variable & Obs. & Mean & Std. Dev. & Min & Max \\
\hline GDP per Cap & 3816 & 6197.634 & 8676.35 & 97.47 & 54482.13 \\
Life Expectancy & 3701 & 64.23717 & 10.95348 & 26.41 & 82.51 \\
CA /GDP & 3722 & -2.747273 & 9.820138 & -240.5 & 56.7 \\
FDI/GDP & 3722 & .032196 & .2041453 & -.5435833 & 5.663656 \\
FPI/GDP & 3459 & .0112529 & .1969966 & -.1285347 & 7.328938 \\
Remittance/GDP & 3195 & .0187416 & .0386861 & 0.0000003747 & .3103261 \\
OFI/GDP & 3702 & $3.19 \mathrm{e}-08$ & $3.04 \mathrm{e}-07$ & $-7.78 \mathrm{e}-06$ & $5.60 \mathrm{e}-06$ \\
Savings/GDP & 3586 & .0964441 & .1174453 & -2.49803 & 1.355369 \\
EAP & 3816 & .6690854 & .1055926 & .36 & .91 \\
RPE & 3816 & 1.017488 & .5071147 & .0133 & 4.5816 \\
\hline
\end{tabular}

\section{Country Categories}

Three country categories are used for this analysis, viz. developed countries (DC), emerging financial markets (EFM) and less-developed countries (LDC). Studies on growth and development either pool the countries together or group them in different income-based categories following the World Bank convention which uses GDP per capita as a means of distinction. Other classifications include OECD and non-OECD countries, industrialized, non-industrialized or transition countries. Based on the World Bank classification, high income countries here are referred to as developed countries. The World Bank term of developing countries denotes a set of low and middle income economies. This classification becomes very complex when involving the emerging 
markets (traditionally viewed as developing countries) which have experienced significant growth in recent years. For this dissertation, countries in the group of lessdeveloped countries are classified as developing countries (low and lower-middle income) excluding the emerging markets.

The third group reported in this dissertation is the emerging markets. According to Beim and Calomiris (2001), the phrase "emerging markets" caught on in the 1990s as countries moved away from state-sponsored methods of development towards opening their economies to foreign capital (primarily foreign private capital). "The International Finance Corporation (IFC), the private sector arm of the World Bank Group, began using the phrase "emerging markets" to describe a set of countries for which they kept and published standardized stock indexes starting in 1981.” (Beim and Calomiris 2001:2) This research utilizes the S\&P classification of emerging financial markets. ${ }^{9}$ Table 3, Table 4 and Table 5 report summary statistics in each category (DC, EFM and LDC) from 1980-2007 to show the differences across the three groups and further justify the categorization of data in these country sub-samples.

\footnotetext{
${ }^{9}$ S\&P classifies 19 countries as emerging markets based on "macroeconomic conditions; political stability; legal property rights and procedures; trading and settlement processes and conditions; and feedback from institutional investors." (Standard \& Poor's Financial Services LLC 2011) 
Table 3: Summary Statistics DC

\begin{tabular}{lccccc}
\hline \multicolumn{1}{c}{ Variable } & Obs & Mean & Std. Dev. & Min & Max \\
\hline Growth & 686 & 2.256895 & 2.271266 & -7.52 & 10.38 \\
gdpcap2000wb & 686 & 20633.9 & 8708.655 & 3221.44 & 54482.13 \\
Life Expectancy & 650 & 77.11986 & 2.254448 & 65.8 & 82.51 \\
Save/GDP & 686 & 0.081632 & 0.054387 & -0.06483 & 0.281214 \\
FDI/GDP & 686 & 0.077819 & 0.460602 & -0.15017 & 5.663656 \\
FPI/GDP & 663 & 0.053874 & 0.447527 & -0.12853 & 7.328938 \\
Remit/GDP & 454 & 0.005001 & 0.013204 & 0 & 0.090299 \\
CA/GDP & 686 & -0.45386 & 4.962257 & -23.96 & 17.32 \\
OFI/GDP & 678 & 0.068053 & 0.280273 & -0.90105 & 3.966948 \\
RPE & 686 & 1.03758 & 0.346516 & 0.19 & 2.4 \\
second & 686 & 971.5994 & 476.4174 & 223 & 3012 \\
work & 686 & 0.63172 & 0.109122 & 0.29 & 0.85 \\
\hline
\end{tabular}


Table 4: Summary Statistics EFM

\begin{tabular}{lrrrrr}
\hline \multicolumn{1}{c}{ Variable } & Obs & Mean & Std. Dev. & Min & Max \\
\hline Growth & 464 & 2.976832 & 4.423988 & -14.32 & 13.7 \\
gdpcap2000wb & 471 & 3342.426 & 4168.02 & 208.17 & 28964.15 \\
Life Expectancy & 462 & 67.57779 & 5.497647 & 51.77 & 80.44 \\
Save/GDP & 465 & 0.142352 & 0.097808 & -0.24656 & 0.436532 \\
FDI/GDP & 470 & 0.027867 & 0.04116 & -0.02758 & 0.520416 \\
FPI/GDP & 467 & 0.003988 & 0.010916 & -0.0458 & 0.103422 \\
Remit/GDP & 373 & 0.018037 & 0.029153 & 0 & 0.145835 \\
CA/GDP & 470 & -0.51087 & 5.905837 & -14.7 & 26.64 \\
OFI/GDP & 470 & 0.012146 & 0.053861 & -0.22849 & 0.424991 \\
RPE & 471 & 0.993631 & 0.420889 & 0.16 & 2.53 \\
second & 471 & 672.9066 & 197.689 & 214 & 1124 \\
work & 471 & 0.566072 & 0.099328 & 0.33 & 0.84 \\
\hline
\end{tabular}


Table 5: Summary Statistics LDC

\begin{tabular}{lccccc}
\hline \multicolumn{1}{c}{ Variable } & Obs & Mean & Std. Dev. & Min & Max \\
\hline Growth & 2059 & 1.13852 & 5.14756 & -46.89 & 37.84 \\
GDP per Cap & 2132 & 2226.9 & 3344.89 & 100.49 & 22302.4 \\
Life & 2102 & 60.2525 & 10.3078 & 26.41 & 79.39 \\
Expectancy & & & & & \\
Save/GDP & 1954 & 0.08429 & 0.13564 & -2.498 & 1.35537 \\
FDI/GDP & 2066 & 0.02353 & 0.05753 & -0.5436 & 1.45202 \\
FPI/GDP & 1834 & 0.00061 & 0.00563 & -0.098 & 0.13381 \\
Remit/GDP & 1913 & 0.02436 & 0.04505 & 0 & 0.31033 \\
CA/GDP & 2066 & -4.0728 & 11.5611 & -240.5 & 54.67 \\
OFI/GDP & 2055 & 0.01997 & 0.36725 & -7.7799 & 5.59732 \\
RPE & 2132 & 1.0094 & 0.49961 & 0.01 & 3.46 \\
second & 2132 & 466.807 & 327.97 & 3 & 1528 \\
work & 2132 & 0.5165 & 0.17348 & 0.02 & 0.9 \\
\hline
\end{tabular}




\section{Chapter - 4}

\section{Analysis and Findings}

This analysis employs various techniques, disaggregated in various dimensions in order to confirm the findings and get robust results. The study employs country-level data based on 120 countries ( 26 developed countries, 18 emerging markets and 77 developing countries) from 1980-2007. The countries in the sample are selected based on data availability for the maximum time-period. A complete list of the countries included in the study is provided in Appendix A.

\section{Reporting Specifications}

The following four specifications are used throughout the analysis to report the findings:

[1] Basic Specification

[2] Basic Specification, excluding Domestic Savings/GDP variable

[3] Extended Specification considering the Interaction of RPE with Financial Variables

[4] Extended Specification considering the Interaction of RPE with Financial Variables, excluding Domestic Savings/GDP variable

Separate models for domestic savings are used to isolate the impact of domestic savings on current account balance. The motivation for using models with and without 
savings comes from Prasad, et al. (2007) argue that the relationship between current account balance and growth runs through domestic savings. To test this assertion, the basic and the extended models are presented once with and once without the domestic savings variable.

To check which specification is superior (basic or extended), Wald test ${ }^{10}$ is performed to test the joint significance of the interaction-term variables used in the extended specification. The Wald test is a method of testing the significance of particular explanatory variables to determine whether the variables should be included in the model. The results of the Wald test ${ }^{11}$ indicate that the extended model is appropriate for the analysis. In addition to the above mentioned specifications, the data is reported for the following sub-samples:

- Whole Dataset

- Developed Countries Sample (DC)

- Emerging Financial Markets (EFM)

- Less Developed Countries Sample (LDC)

As discussed in the previous chapter, there are several motivations for presenting the results in various samples. First, the impact of economic and political variables on

\footnotetext{
${ }^{10}$ Wald test "performs tests of simple and composite linear hypotheses about the parameters of the most recently fitted model" (Stata11 Manual 2011)

${ }^{11}$ Performing Wald Test for testing Joint Significance of the following variables:

( 1) FDI_RPE $=0$

(2) FPI_RPE $=0$

(3) OFI_RPE $=0$

(4) CA_RPE $=0$

(5) Remit_RPE $=0$

(6) Save_RPE =0

$\operatorname{chi} 2(6)=16.54$

Prob $>$ chi2 $=0.0111$

Because the Wald test is significant as seen above, we cannot assume that the parameters associated with these variables are zero; therefore, it makes sense to include these variables in the model.
} 
growth is expected to be different for developed and developing countries. Next, given the outstanding growth of the EFM, especially the BRIC countries (a term coined by the Goldman Sachs Report BRICs and Beyond, detailing the success of Brazil, Russia, India, China and fourteen other EFMs), it is reasonable to present the results for EFM countries separately from developing countries. Furthermore, for LDC sample, in addition to growth in GDP per capita as a measure of Economic Growth, Life Expectancy at birth is used as a dependent variable to determine whether the determinants of growth and development are indeed the same. Results are reported using both dependent variables. Finally, five-year panels (averaging data every five years) are also used for the entire dataset as a matter of robustness and assemble a clear picture of growth over shorter periods of time. Results from five-year panels are reported in the appendices for comparison with other existing cross-section and panel-data studies. Averaging five-year data is also a standard technique employed in the growth literature that utilizes paneldata. The results of five-year averaged data are reported in the appendices and provide further robustness for the findings.

\section{Estimation Methods}

Several estimation techniques are considered in this dissertation based on existing literature on the determinants of growth and development. This analysis uses crosssectional regressions to establishing correlations. A large number of macroeconomic studies on the determinants of economic growth are based on the cross-sectional regression analysis; therefore it is very useful to look at the cross-sectional variation in 
the data. A limitation of the cross-sectional method however, is the inability to exploit time series variation in the data.

Running an Ordinary Least Square (OLS) regression on the entire data is usually a first-step in most empirical work. A pooled OLS regression is applied to the entire dataset without taking into consideration the panel nature of the dataset. It is the most basic form of regression; however, if there is a problem of heteroskedasticity and serial correlation/autocorrelation in the data, the OLS results are inefficient. Furthermore, OLS method does not have the ability to exploit the time-series variation in the data; therefore, panel evidence is used to check whether a consistent relationship holds between foreign and domestic sources of capital, political performance and development.

To decide on which method to use in panel data analysis, it is important to check for heteroskedasticity and serial correlation. To test for serial correlation, the Wooldridge test $^{12}$ for serial correlation is used to test the null hypothesis of no first order autocorrelation. To check for heteroskedasticity the Breusch-Pagan Lagrange Multiplier ${ }^{13}$ test is used for testing the null hypothesis of constant variance. The results from these tests show the data to be heteroskedastic and autocorrelated. To correct for the problem

\footnotetext{
${ }^{12}$ Wooldridge test for autocorrelation in panel data H0: no first-order autocorrelation

$\mathrm{F}(1,135)=45.769$

Prob $>\mathrm{F}=0.0000$
}

The Wooldridge test is significant; therefore there is a problem of serial correlation in the data.

${ }^{13}$ Breusch-Pagan / Cook-Weisberg test for heteroskedasticity Ho: Constant variance Variables: fitted values of Gy $\operatorname{chi} 2(1)=167.12$ Prob $>$ chi $2=0.0000$

The test is significant so the null hypothesis of constant variance is rejected. 
of serial correlation in panel data model, the method of Prais-Winsten is used. This method is used to estimate the parameters $\beta$ when autocorrelation is specified ${ }^{14}$.

For panel data, running a fixed-effects model is usually a reasonable thing to do because it always yields consistent results; however, it may not be the most efficient model and seldom yields useful findings. To compare the explanatory power of the Fixed-Effects model with the Prais-Winsten model, Hausman ${ }^{15}$ test is employed. Hausman test "checks a more efficient model against a less efficient but consistent model to make sure that the more efficient model also gives consistent results." (Warin 2007) Hausman test shows Prais-Winsten to be the ideal method of estimation. However, it is important to note that the more qualified findings are ones that are consistently observed and confirmed using various methods of estimation and various disaggregations of the data; therefore results are reported using cross-sectional analysis, OLS method, fixedeffects model and the ideal analysis given the nature of this dataset, i.e., Prais-Winsten

\footnotetext{
${ }^{14}$ According to Stata Manual (2011), when autocorrelation with panel-specific coefficients of correlation is specified, as is the case here, "each panel-level $\rho$ i is computed from the residuals of an OLS regression across all panels".
}

The panel-by-panel covariance matrix of the disturbances denoted by $\sum_{m \times m}$ is computed as: $\hat{\sum}_{m \times m}=\varepsilon_{i}{ }^{\prime} \varepsilon_{j} / T_{i j}$ with $\varepsilon_{i}$ and $\varepsilon_{j}$ being the respective residuals for panels $i$ and $j$ respectively and $T_{i j}$ being the number of residuals between $i$ and $j$. The pairwise selection is used, and $S_{i j}$ is computed using all observations which are matched by the time period (in this case yearly) between the two panels $i$ and $j$. The Prais-Winsten regression using the procedure described above produces panel corrected standard errors for cross-sectional time-series models with first order autocorrelation and panel-specific AR (1) process.

15 Test: Ho: difference in coefficients not systematic

$$
\begin{gathered}
\text { chi2 }(1)=(b-B)^{\prime}\left[\left(V_{-} \text {b }-V_{-} \_B\right)^{\wedge}(-1)\right](b-B) \\
=0.13 \\
\text { Prob }>\text { chi2 }=0.7204
\end{gathered}
$$

Since the P-value is insignificant, it is safe to use Prais-Winsten Regression 
analysis. The following section reports the findings using the above mentioned methods. Throughout the body of the analysis, only Prias-Winsten regression result tables are presented the evidence from the remainder of the estimation techniques are presented in the appendices.

\section{Whole Sample Evidence}

A large number of existing macroeconomic studies on the connection between capital and growth are based on cross-sectional analysis following Barro and Sala-iMartin (1995); Balasubramanyam et al. (1996); Durlauf et al. (2004). For the purpose of this analysis, cross-sectional evidence is presented for the entire sample 1980-2007, as well as using three time periods, that is 1980-1990, 1990-2000, and 2000-2007 reported in Appendix E. This is to confirm findings across various dimensions and compare results with existing studies on the capital-growth nexus. In the first period (1980-1990), FDI across all four specifications is positive and significant, while other forms of flows such as FPI and OFI (bank loans etc.) as well as domestic savings are negative and insignificant. This is not surprising because the period of 1979-1982 was a bit of a lending frenzy as sovereign loans were syndicated to many small banks that made some very high risk loans to developing countries. (Beim and Calomiris 2001) This risky lending frenzy primarily fueled by the petro-dollars led to debt crisis in various LDCs in East Asia and Latin America, the most notable of which were Brazil and Mexico. However, as the debt crisis was ending, private capital flows started resuming especially to East Asia and the results from 1980-1990 reflect a positive impact of FDI on growth in this period. As noted above, the results from this cross-sectional analysis, although 
intuitive and interesting have limitations because the time-series dimension of the data is not exploited, nor do these results tell us which group of countries are primarily driving the results.

The 1990-2000 time-period marked a surge in private capital, especially FDI, to the emerging markets as well as the post-communist transition countries. However, the period was also affected by two major crises, i.e. the Mexican peso crisis and the EastAsian financial crisis. The cross-section results from this period show that the all forms of capital are negative and insignificant across all specifications, with the exception of FPI in the basic specification without savings. The only form of capital that seems to have a positive impact on growth in all specifications is domestic capital represented by domestic savings. Moreover, when savings is excluded from the model, Current Account balance seems to also be positively related to growth, which shows that the positive sign on the current account is being driven by domestic resources. There is also no evidence for a notable impact of RPE in this time period. The period 2000-2007 also shows a positive impact of domestic resources on growth, as well as the positive link between current account and growth, driven by domestic savings.

The cross sectional analysis showed one consistent finding throughout the three samples, i.e. that current account surplus seems to be positively related to growth, once domestic savings are excluded from the model. In other words, domestic sources of finance seem to be the driver of growth. This finding is also a confirmation of the study by Prasad et al. (2007), who find in their cross-sectional analysis that "correlation between current account and growth is positive and stems largely from a relationship between domestic saving and growth" (2007:170). This finding is however inconsistent 
with neo-classical economic theory which holds that foreign capital permits capitalstarved poor countries to grow by augmenting their resources. Solow model also argued that savings is not a determinant of long term growth. Because cross-sectional analysis has limited estimation power, and it is possible to pick up a phenomenon inherent in the life-cycle of countries, alternative methods are used to explore the link between various forms of capital (foreign and domestic), political performance via RPE and development.

Pooled OLS regression applied to the entire dataset, (which does not have the ability to consider the panel nature of the dataset) is a common approach to explore a relationship between variables. In the OLS regression applied to the whole dataset, FPI has a negative impact on growth in the first two basic specifications and is insignificant for the extended specifications. OFI has a positive impact only in the basic specification and FDI shows no impact on growth at all. The earlier findings on domestic savings and current account balance are also confirmed in this model as current account surplus driven by domestic savings, positively affects growth. In this model, RPE is positive and significant for growth in the extended model and insignificant for the rest. Surprisingly, remittances show a negative impact on growth only in the extended specification and are insignificant for the rest; however, the interaction between RPE and remittances shows a positive impact on growth. This is intuitive because, unless there is capacity to absorb remittances and use them for productive channels, they may not have implications for growth and in some scenarios can even lead to Dutch disease as noted by Ratha (2003). However, this finding requires confirmation across developed country and developing country samples. Along the same lines, current account surplus and OFI, when interacted with RPE show a positive impact on growth in the both the extended specifications, 
which all point to the importance of performance in absorbing external resources for growth. The finding on the positive relationship between growth and the interaction between RPE and current account goes a step further than the argument made by Prasad et al. (2007) who argue that the positive relationship between current account and growth runs through domestic savings. This finding shows that it is the combination of domestic savings and political performance that leads to growth, because capable governments can use savings to promote growth. To find further confirmation of these findings, panel data analysis is employed. ${ }^{16}$

Prais-Winsten regression results reported in Table 6 reported below, lend additional credence to the initial findings on savings, current account surplus and political performance and current account interaction promoting growth. Panel-data applied to the whole sample shows further evidence for a positive impact of FDI and OFI on growth in the basic specification and is insignificant for the extended specification. To explore these findings further, it is important to divide the data in sub-samples to explore whether developed countries, with high levels of political performance and financial development, are driving these results.

A consistent finding throughout these various methods, however, is that while foreign capital flows are not always growth-inducing, domestic sources of financing are crucial for growth. This finding is inconsistent with neo-classical economic theory as well as a majority of empirical studies on growth which do not distinguish between

\footnotetext{
${ }^{16}$ In a panel setting, fixed-effects model always gives consistent results but given the nature of the data, it is not the most efficient model to run. The results from the fixed-effects model also confirm the finding regarding the positive impact of savings and current account surplus on growth. This model also shows a positive impact of FDI, FPI and OFI on growth as well the interaction of political performance with OFI and current account balance, respectively, on growth. However, given the nature of the data, as noted above, Prais-Winsten regression is the most appropriate method.
} 
domestic and foreign sources of investment and give lack of capital as the primary factor for underdevelopment. An insightful way to get robust findings as well to check that the results are simply not inherent phenomenon in the life cycle of countries, it is important to observe growth over short time periods. ${ }^{17}$ To see how this effect holds in short-term, five-year panels are used to report findings in the appendices ${ }^{18}$. A fundamental question put forward by this research is whether countries at different levels of development are impacted differently by various forms of capital. To explore this, the next section turns to finding sample-specific evidence for the capital-growth connection in developed and developing countries.

\footnotetext{
${ }^{17}$ The motivation of doing this is found in Chinn and Prasad (2003) as well as Prasad, Rajan and Subramanian (2007) who argue that poor countries in early stages of their development run current account deficits to finance development once they reach a certain level of growth, they run surpluses to pay off obligations built up by current account deficits.

${ }^{18}$ The time periods considered for finding evidence over short periods are 1980-1985, 1985-1990, 19901995, 1995-2000, and 2000-2005 and the results are presented in the appendices.
} 
Table 6: Panel Data Analysis using Prais-Winsten Regression: Whole Sample

\begin{tabular}{|c|c|c|c|c|}
\hline & Growth[1] & Growth[2] & Growth[3] & Growth[4] \\
\hline gdpcap2000wb & $\begin{array}{l}-0.00002 \\
(0.82)\end{array}$ & $\begin{array}{l}-0.00003 \\
(1.35)\end{array}$ & $\begin{array}{l}-0.00001 \\
(0.69)\end{array}$ & $\begin{array}{l}-0.00002 \\
(0.85)\end{array}$ \\
\hline LifeExpectancy & $\begin{array}{c}0.06490 \\
(3.13)^{* * *}\end{array}$ & $\begin{array}{c}0.07405 \\
(3.66)^{* * * *}\end{array}$ & $\begin{array}{c}0.06872 \\
(3.35)^{* * *}\end{array}$ & $\begin{array}{c}0.07346 \\
(3.60)^{* * *}\end{array}$ \\
\hline FDI_GDP & $\begin{array}{c}1.34121 \\
(2.74)^{* * *}\end{array}$ & $\begin{array}{c}1.66088 \\
(3.07)^{* * * *}\end{array}$ & $\begin{array}{l}-0.76183 \\
(0.09)\end{array}$ & $\begin{array}{l}3.64683 \\
(0.45)\end{array}$ \\
\hline FPI_GDP & $\begin{array}{c}-1.69589 \\
(2.85)^{* * * *}\end{array}$ & $\begin{array}{c}-1.80149 \\
(3.00)^{* * * *}\end{array}$ & $\begin{array}{l}-0.84415 \\
(0.13)\end{array}$ & $\begin{array}{l}-4.15679 \\
(0.66)\end{array}$ \\
\hline OFI_GDP & $\begin{array}{l}2.31606 \\
(3.20)^{* * *}\end{array}$ & $\begin{array}{l}2.35756 \\
(3.34)^{* * * *}\end{array}$ & $\begin{array}{l}2.27103 \\
(0.95)\end{array}$ & $\begin{array}{l}2.66486 \\
(1.19)\end{array}$ \\
\hline Remit_GDP & $\begin{array}{l}8.23889 \\
(2.27)^{* *}\end{array}$ & $\begin{array}{l}9.37830 \\
(2.79)^{* * * *}\end{array}$ & $\begin{array}{l}6.34689 \\
(0.82)\end{array}$ & $\begin{array}{l}4.45356 \\
(0.64)\end{array}$ \\
\hline CAofgdp & $\begin{array}{l}-0.03117 \\
(1.65)^{*}\end{array}$ & $\begin{array}{l}0.00934 \\
(0.51)\end{array}$ & $\begin{array}{c}-0.17502 \\
(4.02)^{* * *}\end{array}$ & $\begin{array}{l}-0.10502 \\
(2.73)^{* * * *}\end{array}$ \\
\hline Save_GDP & $\begin{array}{c}7.19215 \\
(5.14) * * *\end{array}$ & & $\begin{array}{l}9.42666 \\
(3.33) * * *\end{array}$ & \\
\hline RPE & $\begin{array}{l}-0.49765 \\
(1.97)^{* *}\end{array}$ & $\begin{array}{l}-0.21024 \\
(0.89)\end{array}$ & $\begin{array}{l}-0.02329 \\
(0.06)\end{array}$ & $\begin{array}{l}-0.17560 \\
(0.63)\end{array}$ \\
\hline work & $\begin{array}{l}0.79891 \\
(1.04)\end{array}$ & $\begin{array}{l}0.94189 \\
(1.24)\end{array}$ & $\begin{array}{l}1.11206 \\
(1.43)\end{array}$ & $\begin{array}{l}1.05052 \\
(1.38)\end{array}$ \\
\hline FDI_RPE & & & $\begin{array}{l}2.00279 \\
(0.25)\end{array}$ & $\begin{array}{l}-1.88005 \\
(0.25)\end{array}$ \\
\hline FPI_RPE & & & $\begin{array}{l}-0.73475 \\
(0.12)\end{array}$ & $\begin{array}{l}2.36531 \\
(0.39)\end{array}$ \\
\hline OFI_RPE & & & $\begin{array}{l}0.00892 \\
(0.00)\end{array}$ & $\begin{array}{l}-0.39489 \\
(0.17)\end{array}$ \\
\hline CA_RPE & & & $\begin{array}{c}0.14697 \\
(4.05)^{* * *}\end{array}$ & $\begin{array}{c}0.11708 \\
(3.96)^{* * * *}\end{array}$ \\
\hline Remit_RPE & & & $\begin{array}{l}2.28076 \\
(0.37)\end{array}$ & $\begin{array}{l}5.35334 \\
(0.92)\end{array}$ \\
\hline Save_RPE & & & $\begin{array}{l}-2.28654 \\
(1.17)\end{array}$ & \\
\hline _cons & $\begin{array}{c}-3.53784 \\
(2.67)^{* * * *}\end{array}$ & $\begin{array}{c}-3.73938 \\
(2.91)^{* * * *}\end{array}$ & $\begin{array}{c}-4.41998 \\
(3.23)^{* * * *}\end{array}$ & $\begin{array}{c}-3.83244 \\
(2.98)^{* * *}\end{array}$ \\
\hline$R^{2}$ & 0.05 & 0.03 & 0.06 & 0.04 \\
\hline$N$ & 2,382 & 2,453 & 2,382 & 2,453 \\
\hline
\end{tabular}

$* p<0.1 ; * * p<0.05$; *** $p<0.01$ 


\section{Developed Country Evidence}

The results from Prais-Winsten regression results reported in Table-7 (the ideal estimation for this analysis), show a positive impact of FDI and OFI on growth for all specifications, this effect is also significant for FDI in specification [1] and [2] and significant for OFI in [1]. FPI is negative and non-significant. This is as expected, while FDI is expected to be positive in developed countries with high absorptive capacity and advanced financial markets, FPI and OFI are not the most efficient forms of external finance. This finding is also consistent with Iyer et al. (2004) who find FDI to be more growth inducing than FPI and OFI in a sample of 20 OECD countries.

The impact of domestic savings on growth is also positive in the DC sample.

Furthermore, while current account balance is negative and significant for growth in [1], there is no evidence for a positive and significant impact of current account balance on growth in this sample. This implies that the ability of advanced industrialized economies to run current account deficits or to be net borrowers of capital positively impacts their ability to grow, or interpreted conservatively, it does not hinder their ability to grow. As expected, political performance is positive and significant in the [1] and [3] and insignificant for the rest, pointing to the role of a capable government in improving the absorptive capacity of capital.

These findings supports the argument by Prasad et al. (2007) that in rich countries, higher institutional development allows investment to be more responsive to productivity increases and allows citizens to borrow against future wealth ${ }^{19}$. The

\footnotetext{
${ }^{19}$ Prasad, Rajan and Subramanian (2007) argue that industrial countries run current account deficits because investment is relatively more responsive to productivity increases than savings. This argument is
} 
coefficient on the size of the working population is positive and significant in [2] and [4] which are expected because labor is an important factor in growth. Nevertheless, when savings is included in the model, the sign on working population turns negative and becomes insignificant. Partly, this is because size of the working population in some ways is an important determinant of savings. Another interpretation of this finding is that in advanced countries, high levels of growth can be associated with shrinking populations. It is also possible to have growth in presence of unemployment. Finally this result could also point to the inequitable distributional effects of growth in advanced countries.

Secondary education, as expected, has a positive impact on growth as is expected for advanced countries. Life expectancy is insignificant for growth, because advanced countries in general have met the threshold of human development. Finally, the interactions of these terms with RPE do not seem significant for this sample. The next section looks at the emerging financial markets. 
Table 7: Panel Data Analysis using Prais-Winsten Regression: DC Sample

\begin{tabular}{|c|c|c|c|c|}
\hline & Growth[1] & Growth[2] & Growth[3] & Growth[4] \\
\hline gdpcap2000wb & $\begin{array}{l}-0.00000 \\
(0.19)\end{array}$ & $\begin{array}{l}-0.00008 \\
(3.14)^{* * *}\end{array}$ & $\begin{array}{l}-0.00000 \\
(0.07)\end{array}$ & $\begin{array}{l}-0.00008 \\
(3.16)^{* * *}\end{array}$ \\
\hline LifeExpectancy & $\begin{array}{l}0.02284 \\
(0.27)\end{array}$ & $\begin{array}{l}-0.02395 \\
(0.25)\end{array}$ & $\begin{array}{l}0.02934 \\
(0.35)\end{array}$ & $\begin{array}{l}-0.02435 \\
(0.25)\end{array}$ \\
\hline FDI_GDP & $\begin{array}{l}0.78848 \\
(2.32)^{* * *}\end{array}$ & $\begin{array}{l}1.10654 \\
(2.70) * * *\end{array}$ & $\begin{array}{l}4.71029 \\
(0.67)\end{array}$ & $\begin{array}{l}5.35760 \\
(0.69)\end{array}$ \\
\hline FPI_GDP & $\begin{array}{l}-0.93567 \\
(1.62)\end{array}$ & $\begin{array}{l}-1.04812 \\
(1.48)\end{array}$ & $\begin{array}{l}-4.59565 \\
(0.85)\end{array}$ & $\begin{array}{l}-4.56071 \\
(0.75)\end{array}$ \\
\hline OFI_GDP & $\begin{array}{l}1.13654 \\
(1.55)\end{array}$ & $\begin{array}{l}1.93119 \\
(2.27)^{* *}\end{array}$ & $\begin{array}{l}2.68573 \\
(1.09)\end{array}$ & $\begin{array}{l}2.31962 \\
(0.87)\end{array}$ \\
\hline CAofgdp & $\begin{array}{c}-0.14873 \\
(4.17)^{* * * *}\end{array}$ & $\begin{array}{l}0.03437 \\
(1.22)\end{array}$ & $\begin{array}{l}-0.08458 \\
(1.01)\end{array}$ & $\begin{array}{l}0.05293 \\
(0.81)\end{array}$ \\
\hline Save_GDP & $\begin{array}{c}27.71419 \\
(8.70)^{* * * *}\end{array}$ & & $\begin{array}{c}34.39177 \\
(5.36)^{* * *}\end{array}$ & \\
\hline RPE & $\begin{array}{l}1.01935 \\
(2.97)^{* * *}\end{array}$ & $\begin{array}{l}-0.02111 \\
(0.06)\end{array}$ & $\begin{array}{c}1.40584 \\
(2.76)^{* * *}\end{array}$ & $\begin{array}{l}0.02887 \\
(0.08)\end{array}$ \\
\hline work & $\begin{array}{l}-0.84433 \\
(0.61)\end{array}$ & $\begin{array}{l}3.23245 \\
(2.08) * *\end{array}$ & $\begin{array}{l}-0.84270 \\
(0.60)\end{array}$ & $\begin{array}{l}3.25538 \\
(2.10)^{* *}\end{array}$ \\
\hline second & $\begin{array}{l}0.00003 \\
(0.12)\end{array}$ & $\begin{array}{l}0.00006 \\
(0.24)\end{array}$ & $\begin{array}{l}0.00005 \\
(0.19)\end{array}$ & $\begin{array}{l}0.00007 \\
(0.28)\end{array}$ \\
\hline FDI_RPE & & & $\begin{array}{l}-3.67592 \\
(0.56)\end{array}$ & $\begin{array}{l}-3.96258 \\
(0.54)\end{array}$ \\
\hline FPI_RPE & & & $\begin{array}{l}3.39610 \\
(0.67)\end{array}$ & $\begin{array}{l}3.33514 \\
(0.59)\end{array}$ \\
\hline OFI_RPE & & & $\begin{array}{l}-1.37774 \\
(0.60)\end{array}$ & $\begin{array}{l}-0.28315 \\
(0.12)\end{array}$ \\
\hline CA_RPE & & & $\begin{array}{l}-0.05503 \\
(0.72)\end{array}$ & $\begin{array}{l}-0.01642 \\
(0.33)\end{array}$ \\
\hline Save_RPE & & & $\begin{array}{l}-6.42428 \\
(1.05)\end{array}$ & \\
\hline _cons & $\begin{array}{l}-2.34030 \\
(0.36)\end{array}$ & $\begin{array}{l}3.55515 \\
(0.47)\end{array}$ & $\begin{array}{l}-3.36759 \\
(0.52)\end{array}$ & $\begin{array}{l}3.52007 \\
(0.47)\end{array}$ \\
\hline$R^{2}$ & 0.31 & 0.13 & 0.32 & 0.12 \\
\hline$N$ & 626 & 626 & 626 & 626 \\
\hline
\end{tabular}




\section{Emerging Financial Markets Evidence}

The results for emerging financial markets shown in Table 8, show that current account balance is negatively associated with growth in all four specifications, whether or not savings is included. This shows that emerging financial markets utilize large foreign capital inflows and channel them for growth. The political performance variable RPE does show a positive growth impact in [3], in the EFM sample and is insignificant in the remaining samples. It is plausible to argue that EFMs have not caught up with the most developed nations in terms of government efficiency, political stability, governance, financial development, control of corruption and infrastructure. The interaction of current account and RPE is positive, which shows that capable governments which run current account surpluses can promote growth by effective utilization of domestic resources.

Surprisingly, the coefficient on FDI is positive in [1] and [2] however, it is negative and insignificant in the extended specification. This finding should not be taken to mean that FDI flows are unimportant for growth and needs to be interpreted with caution. While a unanimous positive effect of FDI in EFM is expected, it is misleading to assume that FDI inflows yield an automatic positive spillover. Several studies have argued that it is in fact the host country characteristics that determine the impact of FDI inflows. (Balasubramanyam 1996; Iyer, et al. 2004; Moran et al. 2005) The magnitude and significance of the domestic savings coefficient as well as the demographic factors provide a possible explanation for interpreting the impact of foreign capital in EFMs. First, the presence of high domestic savings shows that internal resources are available to domestic firms who wish to compete with foreign firms. Availability of domestic resources is also essential for taking advantage of spillovers from FDI in the form of 
supply chain and backward linkages. Presence of foreign firms can also have other positive spillovers such as technology transfer, improvement in managerial skills and improvement in the skills of labor. Furthermore, the FDI and RPE interaction is positive and significant in both the extended specifications. This also points to the ability of capable government to utilize the inflow of foreign capital.

FPI inflows are positive in all specification and significant in [2], and OFI flows are also positive and significant in all specifications. This finding is consistent with the argument that FPI and OFI flows lead to the development of host financial markets, necessitate institutional development, and improve local managerial skills. (Iyer et al. 2004) Finally, remittances do not seem to be an important source of external finance for the group of EFMs in this sample. 
Table 8: Panel Data Analysis using Prais-Winsten Regression: EFM Sample

\begin{tabular}{|c|c|c|c|c|}
\hline & Growth[1] & Growth[2] & Growth[3] & Growth[4] \\
\hline gdpcap2000wb & $\begin{array}{l}-0.00056 \\
(3.39)^{* * *}\end{array}$ & $\begin{array}{l}-0.00056 \\
(2.97)^{* * *}\end{array}$ & $\begin{array}{l}-0.00059 \\
(3.58)^{* * *}\end{array}$ & $\begin{array}{r}-0.00057 \\
(3.08)^{* * *}\end{array}$ \\
\hline LifeExpectancy & $\begin{array}{c}0.18911 \\
(3.01)^{* * *}\end{array}$ & $\begin{array}{c}0.18754 \\
(2.77)^{* * *}\end{array}$ & $\begin{array}{c}0.18328 \\
(2.90)^{* * *}\end{array}$ & $\begin{array}{r}0.13919 \\
(1.98)^{* *}\end{array}$ \\
\hline FDI_GDP & $\begin{array}{l}6.27749 \\
(0.90)\end{array}$ & $\begin{array}{l}7.33607 \\
(1.02)\end{array}$ & $\begin{array}{c}-16.56473 \\
(0.93)\end{array}$ & $\begin{array}{r}-34.26131 \\
(1.93)^{*}\end{array}$ \\
\hline FPI_GDP & $\begin{array}{l}49.10732 \\
(1.62)\end{array}$ & $\begin{array}{c}59.65824 \\
(1.89)^{*}\end{array}$ & $\begin{array}{c}105.44622 \\
(1.14)\end{array}$ & $\begin{array}{c}131.01443 \\
(1.35)\end{array}$ \\
\hline OFI_GDP & $\begin{array}{c}13.57013 \\
(1.99)^{* *}\end{array}$ & $\begin{array}{c}19.60875 \\
(2.90)^{* * * *}\end{array}$ & $\begin{array}{l}18.77215 \\
(1.05)\end{array}$ & $\begin{array}{r}38.05233 \\
(2.07)^{* *}\end{array}$ \\
\hline Remit_GDP & $\begin{array}{c}-11.04733 \\
(0.83)\end{array}$ & $\begin{array}{l}13.73377 \\
(1.12)\end{array}$ & $\begin{array}{l}-8.66090 \\
(0.68)\end{array}$ & $\begin{array}{c}7.33112 \\
(0.62)\end{array}$ \\
\hline CAofgdp & $\begin{array}{l}-0.10985 \\
(1.61)\end{array}$ & $\begin{array}{l}-0.00521 \\
(0.08)\end{array}$ & $\begin{array}{l}-0.45258 \\
(2.39)^{* *}\end{array}$ & $\begin{array}{c}-0.15116 \\
(0.99)\end{array}$ \\
\hline Save_GDP & $\begin{array}{c}20.28412 \\
(4.84)^{* * *}\end{array}$ & & $\begin{array}{c}37.20462 \\
(4.26)^{* * *}\end{array}$ & \\
\hline RPE & $\begin{array}{l}-0.74449 \\
(1.07)\end{array}$ & $\begin{array}{l}-1.03790 \\
(1.57)\end{array}$ & $\begin{array}{l}1.28019 \\
(1.23)\end{array}$ & $\begin{array}{r}-1.75986 \\
(2.43)^{* * *}\end{array}$ \\
\hline second & $\begin{array}{l}-0.00025 \\
(0.21)\end{array}$ & $\begin{array}{l}0.00108 \\
(0.82)\end{array}$ & $\begin{array}{l}-0.00087 \\
(0.72)\end{array}$ & $\begin{array}{c}0.00012 \\
(0.09)\end{array}$ \\
\hline work & $\begin{array}{l}0.93014 \\
(0.26)\end{array}$ & $\begin{array}{l}6.26639 \\
(1.84)^{*}\end{array}$ & $\begin{array}{l}-0.92930 \\
(0.24)\end{array}$ & $\begin{array}{c}2.89331 \\
(0.81)\end{array}$ \\
\hline FDI_RPE & & & $\begin{array}{l}41.85033 \\
(1.56)\end{array}$ & $\begin{array}{r}71.65727 \\
(2.72)^{* * * *}\end{array}$ \\
\hline FPI_RPE & & & $\begin{array}{c}-71.53236 \\
(0.69)\end{array}$ & $\begin{array}{c}-92.45270 \\
(0.86)\end{array}$ \\
\hline OFI_RPE & & & $\begin{array}{l}-1.81630 \\
(0.12)\end{array}$ & $\begin{array}{c}-15.62221 \\
(1.01)\end{array}$ \\
\hline CA_RPE & & & $\begin{array}{l}0.35493 \\
(2.05)^{* *}\end{array}$ & $\begin{array}{c}0.16794 \\
(1.16)\end{array}$ \\
\hline Save_RPE & & & $\begin{array}{r}-19.02847 \\
(2.85)^{* * *}\end{array}$ & \\
\hline _cons & $\begin{array}{c}-11.17548 \\
(2.32)^{* *}\end{array}$ & $\begin{array}{c}-12.39120 \\
(2.54)^{* * *}\end{array}$ & $\begin{array}{c}-11.36003 \\
(2.25)^{* *}\end{array}$ & $\begin{array}{c}-6.17635 \\
(1.17)\end{array}$ \\
\hline$R^{2}$ & 0.16 & 0.09 & 0.18 & 0.12 \\
\hline$N$ & 363 & 363 & 363 & 363 \\
\hline
\end{tabular}

$* p<0.1 ; * * p<0.05 ; * * * p<0.01$ 


\section{Less-Developed Country Evidence}

Panel-Data evidence in the LDC sample shown in Table 9, lends further credence to the robust relationship between domestic savings and growth. In addition to domestic savings, the most important contributor to development in the LDC sample considered here seems to be remittances. This is consistent with Ratha (2003)who argues that remittances are a consistent and stable source of external financial development for economically fragile countries.

Political performance measured by extraction has less significance for LDCs. A plausible explanation is that most of the countries in the LDC sample are afflicted with rampant corruption. Therefore, the effects of RPE are neutralized by the presence of corruption. As seen in the DC sample, societies that succeed have high performance not only in terms of their ability to extract resources but also in how those resources are utilized. At low levels of development, corruption chew up RPE and resources are wasted in non-productive purposes.

In this sample, the relationship between current account balance and growth is insignificant in the basic specification [1], positive and insignificant in [2] and negative and significant in the extended specification. This finding is somewhat inconclusive; even so, the interaction of RPE and current account balance is more telling. The coefficient on the current account and RPE interaction is both positive and significant, showing that less-developed countries can bootstrap growth through building capacity and using internal savings.

Positive relationships are observed between OFI and growth. This is somewhat expected because capital-starved countries do depend on bank and other lending as an 
important source of external finance. This also explains the positive and significant coefficient on aid, which is another important source of external capital for structurally and economically weak countries. The impact of FPI is insignificant and inconclusive and points to the absence of high levels of financial development which are necessary to reap the benefits from FPI inflows.

FDI in the LDC sample is positive for all specifications. Nonetheless, when domestic savings are removed from the model, FDI coefficient becomes significant in [2] and almost doubles in [4]. One interpretation is that FDI can be growth inducing only when domestic resources are employed in taking advantage of the potential externalities from multinational activity in a host country. In other words, in situations where domestic resources are employed in setting up backward linkages or supply chain catering to the subsidiary of a multinational corporation, or there are technological spillovers to domestic competitors, can the impact of FDI be positive? This finding may be a negation of the widely held assertion that FDI is categorically growth inducing.

The coefficients on life expectancy, size of working population and secondary education as expected are positively related to growth in LDCs. A more interesting question is whether the positive impact of aid, FDI and loans on growth observed in the LDC sample also leads to development? The question is tackled in the next section. 
Table 9: Panel Data Analysis using Prais-Winsten Regression: LDC Sample

\begin{tabular}{|c|c|c|c|c|}
\hline & Growth[1] & Growth[2] & Growth[3] & Growth[4] \\
\hline gdpcap2000wb & $\begin{array}{l}-0.00011 \\
(0.96)\end{array}$ & $\begin{array}{l}-0.00011 \\
(1.10)\end{array}$ & $\begin{array}{l}-0.00001 \\
(0.11)\end{array}$ & $\begin{array}{r}-0.00002 \\
(0.25)\end{array}$ \\
\hline LifeExpectancy & $\begin{array}{l}0.06709 \\
(2.21)^{* *}\end{array}$ & $\begin{array}{l}0.05163 \\
(1.87)^{*}\end{array}$ & $\begin{array}{l}0.06673 \\
(2.30)^{* *}\end{array}$ & $\begin{array}{r}0.04504 \\
(1.67)^{*}\end{array}$ \\
\hline FDI_GDP & $\begin{array}{l}6.28728 \\
(1.44)\end{array}$ & $\begin{array}{c}10.30971 \\
(2.43)^{* *}\end{array}$ & $\begin{array}{l}8.86861 \\
(0.70)\end{array}$ & $\begin{array}{r}17.25472 \\
(1.48)\end{array}$ \\
\hline FPI_GDP & $\begin{array}{l}14.36289 \\
(0.52)\end{array}$ & $\begin{array}{l}6.40383 \\
(0.21)\end{array}$ & $\begin{array}{c}-182.48629 \\
(1.47)\end{array}$ & $\begin{array}{r}-185.85619 \\
(1.51)\end{array}$ \\
\hline OFI_GDP & $\begin{array}{l}2.21695 \\
(2.49)^{* *}\end{array}$ & $\begin{array}{l}2.01430 \\
(2.39)^{* *}\end{array}$ & $\begin{array}{l}2.41467 \\
(0.97)\end{array}$ & $\begin{array}{r}2.15901 \\
(0.91)\end{array}$ \\
\hline Remit_GDP & $\begin{array}{l}9.46265 \\
(2.30)^{* *}\end{array}$ & $\begin{array}{l}9.32773 \\
(2.44)^{* *}\end{array}$ & $\begin{array}{c}10.71127 \\
(2.76)^{* * * *}\end{array}$ & $\begin{array}{r}11.32080 \\
(3.04)^{* * *}\end{array}$ \\
\hline ODA_GDP & $\begin{array}{c}0.00000 \\
(3.14)^{* * *}\end{array}$ & $\begin{array}{l}0.00000 \\
(2.18)^{* * *}\end{array}$ & $\begin{array}{l}0.00000 \\
(3.26)^{* * * *}\end{array}$ & $\begin{array}{r}0.00000 \\
(2.48)^{* * *}\end{array}$ \\
\hline CAofgdp & $\begin{array}{l}-0.00099 \\
(0.05)\end{array}$ & $\begin{array}{l}0.02285 \\
(1.22)\end{array}$ & $\begin{array}{c}-0.14213 \\
(3.65)^{* * *}\end{array}$ & $\begin{array}{r}-0.11148 \\
(2.93)^{* * *}\end{array}$ \\
\hline Save_GDP & $\begin{array}{l}4.70913 \\
(3.30) * * *\end{array}$ & & $\begin{array}{l}3.86509 \\
(2.75)^{* * * *}\end{array}$ & \\
\hline RPE & $\begin{array}{l}-0.25995 \\
(0.95)\end{array}$ & $\begin{array}{l}-0.02357 \\
(0.09)\end{array}$ & $\begin{array}{l}-0.04989 \\
(0.15)\end{array}$ & $\begin{array}{r}0.13825 \\
(0.43)\end{array}$ \\
\hline work & $\begin{array}{l}-0.42047 \\
(0.49)\end{array}$ & $\begin{array}{l}0.32677 \\
(0.40)\end{array}$ & $\begin{array}{l}-0.01438 \\
(0.02)\end{array}$ & $\begin{array}{r}0.55054 \\
(0.68)\end{array}$ \\
\hline second & $\begin{array}{l}0.00025 \\
(0.32)\end{array}$ & $\begin{array}{l}0.00061 \\
(0.82)\end{array}$ & $\begin{array}{l}0.00025 \\
(0.32)\end{array}$ & $\begin{array}{r}0.00066 \\
(0.90)\end{array}$ \\
\hline FDI_RPE & & & $\begin{array}{l}-2.22946 \\
(0.22)\end{array}$ & $\begin{array}{r}-6.37179 \\
(0.66)\end{array}$ \\
\hline FPI_RPE & & & $\begin{array}{c}183.59697 \\
(1.64)\end{array}$ & $\begin{array}{r}183.91844 \\
(1.67)^{*}\end{array}$ \\
\hline OFI_RPE & & & $\begin{array}{l}-0.52986 \\
(0.19)\end{array}$ & $\begin{array}{r}-0.52447 \\
(0.20)\end{array}$ \\
\hline CA_RPE & & & $\begin{array}{l}0.13540 \\
(4.30)^{* * * *}\end{array}$ & $\begin{array}{l}0.12843 \\
(4.31)^{* * * *}\end{array}$ \\
\hline _cons & $\begin{array}{l}-3.64795 \\
(2.16)^{* *}\end{array}$ & $\begin{array}{l}-2.87752 \\
(1.87)^{*}\end{array}$ & $\begin{array}{l}-4.20961 \\
(2.59)^{* * *}\end{array}$ & $\begin{array}{r}-3.02513 \\
(2.00)^{* *}\end{array}$ \\
\hline$R^{2}$ & 0.05 & 0.03 & 0.07 & 0.05 \\
\hline$N$ & 1,588 & 1,659 & 1,588 & 1,659 \\
\hline
\end{tabular}

$* p<0.1 ; * * p<0.05 ; * * * p<0.01$ 


\section{Does Growth mean Development?}

To explore whether the determinants of growth and development are same, Life Expectancy at birth is used as a proxy for development, the choice of this dependent variable is been explained in detail in Chapter 2 and is motivated by Lutz (1995). To analyze the impact of capital (foreign and domestic) and political performance on Life expectancy at birth as a measure of development, results are reported across four specifications ${ }^{20}$ and are presented in Table 10.

Remittances show a positive and significant impact on development across all four specifications. Remittances not only positively impact growth in LDCs, as seen in the previous model; they also lead to higher levels of human development. An added benefit of remittances that are intended for consumption, they are relatively stable in nature Ratha (2003).

FDI inflows also show a positive impact on development, but it is not significant. FPI is positive only in [4] and OFI seems to have a negative impact on development altogether. The model also shows that the size of the working population matters for development across all four specifications.

${ }^{20}[1]$ Life Expectancy $=\mathrm{F}$ (financial variables, domestic savings, controls, RPE)

[2] Life Expectancy y=F(financial variables, controls, RPE)

[3] Life Expectancy $=F$ (financial variables, Domestic savings, controls, RPE, interaction between financial variables*RPE)

[4] Life Expectancy $=\mathrm{F}$ (financial variables, controls, $\mathrm{RPE}$, interaction between financial variables*RPE) 
When development is measured by life expectancy, there is no evidence on the link between savings and development. This result could be a reflection of a loss of confidence in local currency or flight of capital. In other words, at low levels of development, lack of domestic opportunities of capital may prompt smart savings to leave the country, thus reducing development. Finally, current account balance is positive and significant in all four specifications, whether or not savings is included in the model, which again demonstrates that influx of foreign capital does not lead to development in less-developed countries. ${ }^{21}$

The evidence from using Life Expectancy as a measure of development, demonstrated several findings. First, as expected, the analysis showed that the determinants of growth and development are not always the same. Second, foreign capital does not promote development, as seen by the positive link between current account balance and development. Third, remittances show a positive and significant impact on development. The finding regarding remittances is intuitive because remittance earnings can lead to welfare as noted by Ratha (2003) and can also be reinvested by the recipients. The positive, yet insignificant effect of FDI in some ways is also consistent with the line of argument that perhaps the error of non-extractive FDI in developing countries is an error of omission; because a very minor fraction of world non-extractive FDI makes it to very poor countries. Finally, demographic factors affect development more than foreign capital, as seen by the positive and consistent impact of the size of working population on development.

\footnotetext{
${ }^{21}$ This finding is similar to Prasad, Rajan and Subramanian (2007) who argue that for non-industrial countries, foreign capital does not lead to development, using growth in GDP per capita as their measure of development.
} 
Table 10: Panel Data Analysis using Prais-Winsten Regression: LDC Sample

\begin{tabular}{|c|c|c|c|c|}
\hline & $\begin{array}{c}\text { Life } \\
\text { Expectancy[1] }\end{array}$ & $\begin{array}{c}\text { Life } \\
\text { Expectancy[2] }\end{array}$ & $\begin{array}{c}\text { Life } \\
\text { Expectancy[3] }\end{array}$ & $\begin{array}{c}\text { Life } \\
\text { Expectancy[4] }\end{array}$ \\
\hline FDI_GDP & $\begin{array}{r}1.32131 \\
(0.68)\end{array}$ & $\begin{array}{r}1.05828 \\
(0.61)\end{array}$ & $\begin{array}{r}4.57988 \\
(1.06)\end{array}$ & $\begin{array}{r}2.96798 \\
(0.78)\end{array}$ \\
\hline FPI_GDP & $\begin{array}{r}7.17167 \\
(0.54)\end{array}$ & $\begin{array}{r}3.22447 \\
(0.25)\end{array}$ & $\begin{array}{r}20.89366 \\
(0.45)\end{array}$ & $\begin{array}{r}-4.38019 \\
(0.09)\end{array}$ \\
\hline OFI_GDP & $\begin{array}{r}-0.19565 \\
(0.73)\end{array}$ & $\begin{array}{r}-0.10743 \\
(0.43)\end{array}$ & $\begin{array}{r}-1.59958 \\
(1.71)^{*}\end{array}$ & $\begin{array}{r}-1.24348 \\
(1.49)\end{array}$ \\
\hline \multirow{2}{*}{$\begin{array}{l}\text { Remit_GD } \\
\mathrm{P}\end{array}$} & 27.98417 & 22.24964 & 28.51468 & 23.49011 \\
\hline & $(7.10)^{* * *}$ & $(6.17)^{* * *}$ & $(7.62)^{* * *}$ & $(6.68)^{* * *}$ \\
\hline ODA_GDP & $\begin{array}{r}-0.00000 \\
(4.69)^{* * * *}\end{array}$ & $\begin{array}{r}-0.00000 \\
(0.02)\end{array}$ & $\begin{array}{r}-0.00000 \\
(4.80)^{* * * *}\end{array}$ & $\begin{array}{r}-0.00000 \\
(0.02)\end{array}$ \\
\hline CAofgdp & $\begin{array}{r}0.00397 \\
(0.41)\end{array}$ & $\begin{array}{r}0.00332 \\
(0.48)\end{array}$ & $\begin{array}{r}0.00218 \\
(0.18)\end{array}$ & $\begin{array}{r}0.00272 \\
(0.29)\end{array}$ \\
\hline Save_GDP & $\begin{array}{r}0.01736 \\
(0.02)\end{array}$ & & $\begin{array}{r}0.19721 \\
(0.22)\end{array}$ & \\
\hline RPE & $\begin{array}{r}-0.08717 \\
(0.34)\end{array}$ & $\begin{array}{r}0.22536 \\
(0.74)\end{array}$ & $\begin{array}{r}-0.04778 \\
(0.19)\end{array}$ & $\begin{array}{r}0.28120 \\
(0.92)\end{array}$ \\
\hline work & $\begin{array}{r}3.21108 \\
(2.57)^{* *}\end{array}$ & $\begin{array}{r}-2.10275 \\
(2.02)^{* *}\end{array}$ & $\begin{array}{l}4.60424 \\
(3.81)^{* * *}\end{array}$ & $\begin{array}{r}-1.64390 \\
(1.69)^{*}\end{array}$ \\
\hline second & $\begin{array}{r}0.01652 \\
(25.75)^{* * *}\end{array}$ & $\begin{array}{r}0.01676 \\
(17.05)^{* * *}\end{array}$ & $\begin{array}{r}0.01701 \\
(29.56)^{* * *}\end{array}$ & $\begin{array}{r}0.01716 \\
(18.20)^{* * * *}\end{array}$ \\
\hline FDI_RPE & & & $\begin{array}{r}-2.66830 \\
(0.81)\end{array}$ & $\begin{array}{r}-1.62996 \\
(0.57)\end{array}$ \\
\hline FPI_RPE & & & $\begin{array}{r}-12.41013 \\
(0.31)\end{array}$ & $\begin{array}{r}6.33461 \\
(0.15)\end{array}$ \\
\hline OFI_RPE & & & $\begin{array}{r}1.74042 \\
(1.59)\end{array}$ & $\begin{array}{r}1.47536 \\
(1.50)\end{array}$ \\
\hline CA_RPE & & & $\begin{array}{r}0.00435 \\
(0.40)\end{array}$ & $\begin{array}{r}0.00389 \\
(0.40)\end{array}$ \\
\hline _cons & $\begin{array}{l}51.61413 \\
(63.32)^{* * *}\end{array}$ & $\begin{array}{l}53.55994 \\
(54.40)^{* * *}\end{array}$ & $\begin{array}{l}50.72111 \\
(67.28)^{* * *}\end{array}$ & $\begin{array}{l}53.07584 \\
(59.24)^{* * *}\end{array}$ \\
\hline$R^{2}$ & 0.97 & 0.97 & 0.97 & 0.97 \\
\hline$N$ & 1,599 & 1,679 & 1,599 & 1,679 \\
\hline
\end{tabular}

$* p<0.1 ; * * p<0.05 ; * * * p<0.01$ 


\section{Robustness Checks using Five-Year Panel Averages}

Because annual growth rates fluctuate a lot, a number of studies use dataset presented in five-year averages to get consistent findings (such as Prasad et al. 2007). Table 11 presents results by transforming the data into five-year averages. In developed countries, current account balance is negatively related to growth confirming the finding that advanced countries have the capacity to absorb foreign capital and grow by reliance on external finance. While the impact of FDI in not positive as expected, Iyer et al. (2004) point to the measurement of spillovers as suspect. They argue that in developed countries, spillovers depend on technology gaps and observe that "small gaps encourage spillovers while large gaps inhibit them.” (2004:9) OFI has a negative impact in the DC sample, which makes sense because OFI flows are not a very important source of capital in DCs. Domestic savings and secondary education, as expected and consistent with previous results, they are also important for development in DCs. The size of the working population is negatively related to growth, similar to the panel data evidence presented earlier and points to the possibility of growth in presence of unemployment or inequitable distribution of growth. Political performance in the DC sample is positively related to growth. This shows that highly capable governments have the ability to absorb foreign capital as well as channel domestic resources for development.

In emerging markets, FDI and FPI foster growth, similar to the earlier findings. Furthermore, domestic savings and current account balance are positively related to growth, which shows the importance of domestic resources in utilizing foreign capital. 
Table 11: Results from Five Year Averaged Data

\begin{tabular}{|c|c|c|c|c|}
\hline & Growth[1] & Growth[2] & Growth[4] & Life Expect. \\
\hline & $\mathrm{DC}$ & EFM & LDC & LDC \\
\hline \multirow[t]{2}{*}{ gdpcap2000wb } & -0.00001 & -0.00072 & -0.00017 & - \\
\hline & $(0.86)$ & $(8.89) * * *$ & $(5.09)^{* * *}$ & \\
\hline \multirow[t]{2}{*}{ LifeExpectancy } & 0.03656 & 0.14083 & 0.04735 & - \\
\hline & $(1.30)$ & $(4.44) * * *$ & $(4.78)^{* * *}$ & \\
\hline \multirow[t]{2}{*}{ FDI_GDP } & -4.22075 & 93.70192 & 20.56353 & -3.93824 \\
\hline & $(3.28) * * *$ & $(8.87)^{* * *}$ & $(9.50)^{* * *}$ & $(0.65)$ \\
\hline \multirow[t]{2}{*}{ FPI_GDP } & 8.17361 & -123.07233 & 181.85793 & 738.22782 \\
\hline & $(3.92)^{* * *}$ & $(3.68) * * *$ & $(4.12)^{* * *}$ & $(5.94)^{* * * *}$ \\
\hline \multirow[t]{2}{*}{ OFI_GDP } & -3.76516 & 8.43448 & 5.82704 & 10.94927 \\
\hline & $(2.44)^{* *}$ & $(1.90)^{*}$ & $(7.06)^{* * *}$ & $(4.77) * * *$ \\
\hline \multirow[t]{2}{*}{ Remit_GDP } & - & -28.94751 & 6.73470 & 66.15457 \\
\hline & & $(5.89)^{* * *}$ & $(4.16)^{* * *}$ & $(16.05)^{* * *}$ \\
\hline \multirow[t]{2}{*}{ CAofgdp } & -0.10994 & 0.17080 & 0.03559 & 0.17038 \\
\hline & $(4.05)^{* * *}$ & $(3.36)^{* * *}$ & $(3.70)^{* * *}$ & $(6.61)^{* * *}$ \\
\hline \multirow[t]{2}{*}{ Save_GDP } & 21.76044 & 7.74718 & 2.39701 & -9.97904 \\
\hline & $(13.73)^{* * *}$ & $(3.15)^{* * *}$ & $(3.26)^{* * *}$ & $(4.87)^{* * *}$ \\
\hline \multirow[t]{2}{*}{ RPE } & 2.61424 & -1.99031 & -0.99978 & -0.46799 \\
\hline & $(12.75) * * *$ & $(4.27)^{* * * *}$ & $(6.50)^{* * *}$ & (1.09) \\
\hline \multirow[t]{2}{*}{ second } & 0.00209 & -0.00502 & -0.00010 & 0.02181 \\
\hline & $(6.65)^{* * *}$ & $(6.25)^{* * *}$ & $(0.35)$ & $(40.04)^{* * *}$ \\
\hline \multirow[t]{2}{*}{ work } & -1.46245 & -5.80090 & -0.40497 & -0.60666 \\
\hline & $(2.48)^{* *}$ & $(3.50)^{* * *}$ & $(1.12)$ & $(0.59)$ \\
\hline \multirow[t]{2}{*}{ _cons } & -5.74442 & 2.07215 & -0.87695 & 50.74180 \\
\hline & $(2.90)^{* * *}$ & $(0.95)$ & $(1.56)$ & $(63.87)^{* * *}$ \\
\hline$R^{2}$ & 0.62 & 0.66 & 0.16 & 0.59 \\
\hline$N$ & 440 & 297 & 1,493 & 1,509 \\
\hline
\end{tabular}


In EFM sample, politics does not matter; this result may be a neutralization of RPE by corruption which is an ongoing still issue in many EFM. Finally, working population is negatively associated with growth, pointing to the inequitable distribution of benefits from financial globalization.

In the two LDC models, it is evident that growth and development are not the same. While FDI leads to growth, it does not affect human development. Savings boosts growth; nonetheless, it negatively affects development. This can be interpreted as domestic savings leaving the country and the benefits of growth being concentrated among a few. In both models the current account balance is positively related to growth as well as development; it is clear from this finding that influx of foreign capital is not the development solution to the woes of LDCs. Furthermore, external capital such as aid prevents inefficient governments in LDCs to enlist the cooperation of the population. A better strategy for LDCs to boost growth and reach higher levels of development is to bootstrap their development on domestic resources. Furthermore, improving political performance through extraction may be a first step, but it is not enough. The next step for LDCs should be to ensure that resources extracted from the population are not wasted or fall prey to corruption but rather are allocated efficiently.

\section{Summary}

The evidence reported above from the three country samples of DCs, EFMs and LDCs showed that external finance is not always the key to development. While, external finance can play an important role in the economic growth in DCs, which have the financial and political infrastructure in place to absorb foreign capital, the reverse is true 
for structurally and economically weak states. This relationship was demonstrated by the positive link between current account balance and development in EFM and LDC samples and a negative link between current account balance and development in DCs. Furthermore, the analysis also showed that the type of investment matters. While FDI has been an important source of development finance in EFMs, portfolio investments have been volatile and have the ability to make these countries vulnerable to macroeconomic instability. At the same time, in LDCs, FDI has been very volatile and has been primarily focused on extractive industries. Therefore, growth associated with FDI in LDCs has not translated to improvements in human development.

Remittances seem to demonstrate a positive impact on growth as well as development in LDCs. However, a problem with remittances is that they are driven by migration, and in most cases especially in the case of sub-Saharan Africa, the benefit of Remittances has been neutralized with the brain drain or loss of a large percentage of educated workforce in LDCs (UNCTAD 2007). Therefore while remittances can be harnessed for development, the best development policies should focus on improving political performance and creating better opportunities at home which would discourage migration in the first place.

An important finding of this dissertation was that domestic savings play a positive and significant role in economic growth in all three country sample. Domestic savings do not automatically imply domestic investment, and in fact governments can invest a large percentage of savings in foreign assets, as has been observed in many EFMs. Reliance on domestic resources further gives weak countries the ability to implement development policies that are free from external influence as opposed to ODA, which is usually donor 
driven. In the case of LDCs however, while savings show a positive impact on growth, they have a negative impact on development. An explanation for this finding is the flight of capital from the country as well as the lack of profitable investment opportunities at home. This has already been observed in Africa, where flight of capital has robbed the continent of its much needed domestic resources. According to an UNCTAD (2007) report, it is Africa's political and economic elites who are primarily engaged in capital flight using means such as "trade misinvoicing, embezzlement of tax revenue, exports and aid, and kick back on contracts" (UNCTAD 2007: 38). This shows that solution to the problem of mismanagement of domestic resources is not only an improvement in banking and financial sector and increasing investment opportunities but it is also directly related to improvement in political performance. Thus while domestic resources are more desirable for countries on the path to development, demonstrated by the positive relationship between current account balance and development, improvement in political performance is key for the proper utilization of domestic resources and for discouraging capital flight. Improvement in the tax sector can increase government revenue extraction and improve governance. However, in a lot of LDCs there is a loss of confidence in the governments' abilities properly allocate the resources for policy goals that meet development objectives. Although this dissertation did not address the impact of allocation and political reach components of political performance in improving the efficiency of investments, future research should look at these components to provide further insight into this relationship. 


\section{Chapter - 5}

\section{Conclusion and Implications}

This study aimed to contribute to the existing literature on growth and development by considering the question of what kinds of capital flows foster economic development in developing countries, given the political performance of each country. For this purpose, the study used a variety of methods including cross-section, OLS and panel data analysis using a dataset of 120 countries from the years 1980-2007. This dataset was further divided into developed countries, emerging markets and lessdeveloped countries. This study made the case that growth and development do not always go hand in hand, especially in the case of fragile states. Hence two models were considered for exploring the impact of various forms of capital flows on the economic growth and human development. The main finding for this study was that domestic resources of finance are superior to foreign capital for developing countries.

The first question this study addressed was to determine whether or not and to what extent foreign capital benefits poor societies, or is it domestic sources of finance that are the most important for development. The dissertation first looked at current account balance, a composite measure that shows whether countries are net import or net exporters of capital. The results from looking at current account balance showed that in less-developed countries, current account balance is positively associated with economic 
growth and development. Furthermore, a positive relationship was observed for the interaction between current account and political performance measured by RPE, on growth. In the case of developed countries, the results indicated that running current account deficits was positively linked to growth; pointing to the ability of these countries to absorb and utilize foreign investments. The evidence regarding current account balance in emerging markets is mixed, perhaps due to the constantly evolving nature of these countries.

The policy implication of this finding is that poor countries differ in their abilities to absorb capital from rich countries. While liberalizing the current account and encouraging foreign capital flows may be a sound policy for developed countries, the results from this study indicate that it may not be so for developing countries. Instead, developing countries, especially low income developing countries may have better success in utilizing domestic resources such as domestic savings for improving economic growth and creating the conditions under which foreign capital can be beneficial.

In addition to looking at current account balance, this study also looked separately at the impact of domestic savings as well as foreign sources of finance such as FDI, FPI, OFI and Remittances on growth and development. The analysis determined that the determinants of growth and development are indeed different. In the case of growth, domestic savings seem to be the most important factor in growth, and in fact foreign capital seems to be of relatively less importance than what a large number of studies claim. However, domestic savings seemed to be less important for human development in less developed country sample. This result again indicates the flight of capital scenario; in absence of strong and efficient governments and fewer profitable opportunities for 
investment at home, domestic resources are channeled abroad rather than being invested at home where they are most needed. Even countries that have experienced respectable savings, find their resources fleeing the country. The capital flight from sub-Saharan Africa alone from 1970-1996 was reported to be a $\$ 285$ billion, while the combined debt for the region was $\$ 178$ billion in 1996, making it a net creditor vis-à-vis the rest of the world (UNCTAD 2007: 29). This shows that the issue is less of resource constraint and more of a lack of political performance, poor tax structures and incapable governments and therefore calls for an improvement in RPE.

In the case of emerging markets, FDI had positive and significant impact on growth only when domestic savings were accounted for. This result can be interpreted as the confirmation that FDI is useful only when there are enough domestic resources to take advantage of positive externalities such as supply chains and backward linkages, as is the case of some manufacturing and assembly related FDI. This result can be construed as a confirmation of the proposition by Moran (2005) that FDI has positive externalities in manufacturing and assembly sectors, under certain conditions and can be detrimental in the mining sector.

FDI also seems to have a positive impact on human development. Thus the implication of this finding is that governments should create incentives for FDI in sectors where spillovers are the greatest and by employing domestic resources to capture these positive externalities. Alternatively, this finding can also be used as a motivation to tax extractive FDI. The results also shows that in less-developed countries, savings may even be a prerequisite for attracting and efficiently utilizing foreign direct investment, as seen by the positive FDI effect due to savings. 
The study did not find any conclusive impact of FPI and OFI in less-developed countries, and in some cases, these capital flows seem to be detrimental to development. Furthermore, the impact of aid on human development was negative, showing that reliance on foreign aid is not an effective development strategy.

Remittances seem to have a positive impact on both growth as well as development in developing countries. The potential policy implications of this finding can be to provide further incentives to attract remittances. It would therefore be worthwhile for the government to pursue policies that reduce remittance fees and improve transfer technologies such as mobile money transfer which is critical to the remittance market (Ratha et al. 2010). However, remittances which are a result of migration are associated with a loss of a large percentage of educated and well-trained workforces in less developed countries. The best polices would therefore be those that focus on creating opportunities at home.

An important finding of this research supports the claim that correlates of income growth and life-expectancy (as a measure of development) are not the same. This research also confirms that not all types of capital flows are equal in their growth and developmental impact. While domestic resources are most important for development, maximizing the impact of these resources depends on improvement in capability of governments. Understanding this issue goes to the core of development, as developing countries determine the form and extent of capital flows that are most suitable in their particular setting. Moreover, improving government performance is the key to not only successful utilization of foreign capital for development but also efficient utilization of domestic resources. A limitation of this study however, is that it only uses RPE to 
indirectly measure political performance. Future research on the subject should incorporate the other two dimensions of political performance, viz. RPR and RPA, as data on this becomes available. Incorporating the RPR dimension of performance should show the extent to which the reach of the governments impacts the utilization of capital, both foreign and domestic for development. Improvements in RPR can also provide insight into how domestic household savings in the informal sector can be efficiently utilized. Similarly, RPA should reflect how effectively the government is allocating resources to meet its development objectives. The insights from using RPE as a measure of performance in this analysis have shown that not only does the type of investments matter, but the capability of the government also matters in effectively utilizing finance to meet development objectives. 


\section{Bibliography}

Acemoglu, Daron. Introduction to Modern Economic Growth. New Jersey: Princeton University Press, 2009.

Acemoglu, Daron, Simon Johnson, and James A. Robinson. "The Colonial Origins of Comparative Development: An Empirical Investigation." American Economic Review 91, no. 5 (2001): 1369-1401.

Aizenman, Joshua, and Mark M. Spiegel. "Institutional Efficiency, Monitoring Costs and the Investment Share of FDI." NBER Working Paper No. 9324, 2004.

Akcay, Selcuk. "Is Corruption an Obstacle for Foreign Investors in Developing." Yapi Kredi Economic Review, 2001: 27-34.

Arbetman, Marina, and Jacek Kugler. Political capacity and economic Behavior. Westview press, 1997.

Arbetman-Rabinowitz, Marina, and Kristin Johnson. "Oil...Path to Prosperity or Poverty? The Effects of Political Capacity in Africa." 2009.

—. Relative Political capacity: Empirical and Theoretical Underpinnings. Claremont, 2007.

Bahl, Roy W. "A Regression Approach to Tax Effort and Tax Ratio Analysis." (IMF Staff Papers) 18 (November 1971).

Balasubramanyam, VUDAYAGIRI N., MMOHAMMED Salisu, and DAVID SAPSFORD. "Foreign Direct Investment and Growth in EP and is Countries." The Economic Journal 106, no. 434 (1996): 92-105.

Bardhan, Pranab. Scarcity, Conflicts, and Cooperation: Essays in Political and Institutional Economics of Development. MIT Press, 2004.

Barro, Robert. "Democracy and Growth." Journal of economic Growth, 1996: 2-27.

-. Determinants of Economic Growth: A Cross-Country Empirical Study. Cambridge: MIT Press, 1998.

Barro, Robert. "Economic Growth in a Cross Section of Countries." Quarterly Journal of Economics 106, no. 2 (1991): 407-43.

Barro, Robert J., and Xavier Sala-i-Martin. "Convergence." Journal of Political economy, no. 100 (April 1992): 223-51. 
—. Economic growth. McGraw-Hill, 1995.

Beim, David O., and Charles W. Calomiris. Emerging financial markets. McGraw-Hill Irwin, 2001.

Blonigen, Bruce A., and Miao G. Wang. "Inappropriate Pooling of Wealthy and Poor Conuntries in Empirical FDI Studies." In Does Foreign Direct Investment Promote Development?, by Theodore H. Moran, Edward M. Graham and Magnus Blomstrom, 221-244. Washington, DC: Center for Global Development, 2005.

Blossier, Felix. "Migradollars and Economic Development: Characterizing the Impact of Remittances on Latin America." Council on Hemispheric Affairs, May 6, 2010.

Bornschier, Volker. "Multinational corporations and economic growth : A cross-national test of the decapitalization thesis." Journal of Development Economics 7, no. 2 (April 1980): 191-210.

Bornschier, Volker, and Christopher Chase-Dunn. Transnational Corporations and Underdevelopment. New York: Praeger, 1985.

Brogger, Tasneem. "East Europe's Main Challenge is Guiding Capital Flows." Bloomberg Business Week, May 11, 2010.

—. "East Europe's Main Challenge is Guiding capital Flows." Businessweek, May 11, 2010.

Brown, Kevin. "Asian Emerging Economies may Contemplate Capital Controls." Financial Times, May 18, 2010.

Brune, Nancy, and Alexandra Guisinger. The Diffusion of Capital Account. UCLA, 2003.

Buch, Claudia M., and Anja Kuckulenz. "Worker Remittances and Capital Flows to Developing Countries." Centre for European Economic Research Discussion Paper No. 04-031, April 2004.

Buch, Claudia M., Anja Kuckulenz, and Marie-Helene Le Manchec. "Worker Remittances and Capital Flows." Kiel Working Paper No. 1130, 2002.

Burnside, Craig, and David Dollar. "Aid, policies, and growth : revisiting the evidence." The World Bank Policy Research Working Paper Series 3251 (2004).

Burnside, Craig, and David Dollar. "Aid, Policies, and Growth." American Economic Review 90, no. 4 (2000): 847-868.

Calafell, Javier Guzmán. Improving the Allocation of Domestic Saving for Economic Development. Banco de México, 2003.

Cohen, Stephen. Multinational Corporations and Foreign Direct Investment: Avoiding Simplicity, Embracing Complexity. New York: Oxford University Press, 2007. 
de Soya, Indra. Foreign Direct Investment, Democracy \& Development: Assessing Contours, Correlates, and Concomitants of Globalization. London: Routledge, 2003.

Dixon, William, and Terry Boswell. "Dependency, Disarticulation, and Denominator effects: Another Look at Foreign Capital Penetration." American Journal of Sociology 102, no. 2 (1996): 576-784.

Durlauf, Steven N., Paul A. Johnson, and Jonathan R. W. Temple. "Growth Econometrics." (University of Wisconsin) 2004.

Easterly, William. "Can Foreign Aid Buy Growth?" Journal of Economic Perspectives 17, no. 3 (2003): 23-48.

Easterly, William. "The Political Economy of Growth Without Development." World Bank, 2001: $1-53$.

Egger, Peter, and Hannes Winner Winner. "How Corruption Influences FDI: A Panel Data Study." European Journal of Political Economy 21 (2006): 932-952.

Eichengreen, Barry. Capital Flows and Crisis. Cambridge, Massachusetts : MIT Press, 2004.

Eichengreen, Barry, and David Leblang. "Democracy And Globalization." Economics and Politics (Blackwell Publishing) 20, no. 3 (2008): 289-334.

Erdilek, Asim. "R\&D Activities of Foreign and National Establishments in Turkish Manufacturing." In Does Foreign Direct Investment Promote Development?, by Theodore H. Moran, Edward M. Graham and Magnus Blomstrom, 107-136. Washington DC: Center for Global Development, 2005.

Firebaugh, Glenn. "Growth Effects of Foreign And Domestic Investment." American Journal of Sociology 98, no. 1 (1992): 105-30.

Globerman, Steven, and Danel Shapiro. "Governance Infrastructure and U.S." International Finance Working Paper, 2002.

Gruben, William. C., and Darryl Mcleod. "Capital flows, savings and growth in the 1990s." The Quarterly Review of Economics and Finance 38 (1998): 287-301.

Henry, Peter Blair. "Capital Account Liberlization: Theory, Evidence and Speculation." National Bureau of Economic Research Working Paper 12698 (November 2006).

International Monetary Fund. Balance of Payments Manual. 5th Edition. Washington D.C.: IMF, 2009.

—. International Financial Statistics CD-ROM. Washington DC: IMF, 2010.

Iyer, Krishna G., Alicia N. Rambaldi, and Kam Ki Tang. Measuring Spillovers from Alternative Forms of Foreign Investment. St Lucia: University of Queensland, 2004. 
Kamewe-Tsafack, Hugues. The Virtues of Savings Mobilization for Economic Development in Africa. Africa Finance Forum: Making Finance work for Africa, 2010.

Kaufmann, Daniel, Aart Kraay, And Pablo Zoido-Labato `N. "Governance matters: II." Policy Research Working Paper vol. 2772 (World Bank), 2002.

Kehl, Jenny Rebecca. "Direct Investment, Economic and Democratic Development." Journal of Economics, Banking and Finance 2, no. 2 (2008).

Kelley, Allen C. "The Human Development Index: "Handle with Care"." Population and Development Review 17, no. 2 (June 1991): 315-324.

Kyaw, K. Sandar, and Ronald Macdonald. "Capital Flows and Growth in Developing Countries: A Dynamic Panel Data Analysis." Oxford Development Studies (Routledge), no. 2 (June 2009): 101-122.

Langbein, Laura, and Stephen Knack. "The Worldwide Governance Indicators: Six, One, or None?" Journal of Development Studies, 2010: 350-370.

Levine, Ross. "Financial Development and Economic Growth: Views and Agenda." Journal of Economic Literature, 1997: 688-726.

Lopez-Cordova, Ernesto, and Christopher Meissner. "The Globalization of." NBER Working Ppaer no. 11117, 2005.

Lotz, Jorgen R., and Elliot Morse. "Measuring "Tax Effort" in Developing Countries." IMF Staff Papers 14 (1967).

Lucas Jr, Robert E. "Why doesn't capital flow from rich to poor countries?" American Economic Review 80 (1990): 92-6.

Lutz, Wolfgang. "Literate life expectancy. Proposing a powerful new indicator of social development." POPNET (International Institute for Applied Systems Analysis) 23 (Summer 1995): 1-11.

Mankiw, N. Gregory, David Romer, and David N. Weil. "A Contribution to the Empirics of Economic Growth." Quarterly Journal of Economics 107 (May 1920): 407-37.

Mishra, Deepak, Ashoka Mody, and Antu Panini Murshi. "Private Capital Flows and Growth." Finance and Development 38, no. 2 (2001): 2-5.

Musgrave, R. A. "Who Should Tax, Where, and What?" In Tax Assignment in Federal Countries, by Jr. Charles E. McLure. Canberra: Centre for Research on Federal Financial Relations, Australian National University, 1983.

North, Douglass C. Institutions, Institutional Change and Economic Performance. Cambridge: Cambridge University Press, 1990. 
North, Douglass. "Institutions and economic Growth: An Historical Introduction." World Development 17 9, no. 1 (1989): 319-32.

Organski, A.F.K., and Jacek Kugler. The War Ledger. Chicago: Chicago University Press, 1980.

Perkins, Dwight H., Steven Radelet, and David L. Lindauer. Economics of Development. W. W. Norton, 2001.

Prasad, Eswar S., Raghuram G. Rajan, and Arvind Subramanian. "Foreign capital and Economic Growth." Brookings Papers on Economic Activity, 2007.

Przerworski , Adam. "The Last Instance: Are Institutions the Primary Cause of Economic Development." European Journal of Sociology 45, no. 2 (2004): 165-188.

Przerworski, Adam, and FERANDO LIMONGI. "Political Regimes and Economic Growth." Journal of economic perspectives, 1993: 51-79.

Quinn, Dennis. Democracy and International Financial Liberalization. Georgetown University: unpublished manuscript, 2001.

Rajan, Raghuram, and Arvind Subramanian . "Does Aid Affecr Governance?" American Economic Review, 97, no. 2 (2007): 322-327.

Ratha, Dilip. "Workers' Remittances: An Important and Stable Source of External Development." In Global Development Finance: Striving for Stability in Development Finance, 157-175. Washington D.C.: World Bank, 2003.

Rodrik, Dani, Arvind Subramanian , and Francesco Trebbi. "Institutions Rule: The Primacy Of Institutions Over Geography And Integration In Economic Development." Journal of Economic Growth 9, no. 2 (July 2004): 131-165.

Sachs, Jeffrey D. "Notes on a New Sociology of Economic Development." In ulture Matters: How Values Shape Human Progress, by Lawrence E. Harrison and Samuel P. Huntington. New York: Basic Books, 2000.

Sala-i-Martin, Xavier. "Cross-Sectional Regressions and the Empirics of Economic Growth." Economics Working Paper 79 (Yale University and Universitat Pompeu Fabra), May 1984.

Sen, Amartya. Development as Freedom. New York: Alfred Knopf, 2001.

Solow, Robert. "Contribution to the Theory of Economic Growth." Quarterly Journal of Economics 70 (February 1956): 65-94.

StataCorp. "Stata Statistical Software: Release 11." College Station, TX, 2010.

Tammen, Ronald, and Jacek Kugler, . Performance of Nations. Lanham. MD: Rowman \& Littlefield, 2012. 
The Economist. "Falling foreign direct investment." The Economist; , February 12, 2010.

Tong, Hui, and Shang-Jin Wei. "The Composition Matters: Capital Inflows and Liquidity Crunch During a Global Economic Crisis." IMF Working Paper, 2009.

United Nations Development Programme. Human Development Report. New York: United Nations Development Programme, 2009.

Vita, Glauco de, and Khine S. Kyaw. "Growth effects of FDI and portfolio investment flows to developing countries: a disaggregated analysis by income levels." Applied Economics Letters (Routledge) 16 (2009): 277-283.

Wolfson, Michael. "Divergent Inequalities: Theory and Empirical Results." Review of Income and Wealth 43, no. 4 (1997): 401-21.

World Bank. "Challenges in Managing Capital Flows." In Global Development Finance. New York: Oxford UniversityPress, 2006.

—. Migration and Development Brief. Oxford University Press, 2008.

-. World Bank Annual Review of Development Effectiveness . New York: Oxford University press, 2006.

—. World Development Indicators Online (WDI) database. 2010. http://data.worldbank.org/datacatalog/world-development-indicators (accessed September 2010).

Yu, Miaojie. Trade Globalization and Political Liberalization: A Gravity. University of California, Davis, 2005. 


\section{Appendix A- Country Samples}

Table A-1: Country Samples

\begin{tabular}{|c|c|c|}
\hline & DC Countries & EFM Countries \\
\hline & Australia & 1 Brazil \\
\hline 2 & Austria & 2 Chile \\
\hline 3 & Canada & 3 China, P.R.: Mainland \\
\hline 4 & Cyprus & 4 Egypt \\
\hline 5 & Denmark & 5 Hungary \\
\hline 6 & Finland & 6 India \\
\hline 7 & France & 7 Indonesia \\
\hline 8 & Germany & 8 Malaysia \\
\hline 9 & Greece & 9 Mexico \\
\hline 10 & Iceland & 10 Morocco \\
\hline 11 & Ireland & 11 Peru \\
\hline 12 & Israel & 12 Philippines \\
\hline & Italy & 13 Poland \\
\hline 14 & Japan & 14 Russia \\
\hline & Korea, Republic of & 15 Singapore \\
\hline & Luxembourg & 16 South Africa \\
\hline & Netherland & 17 Thailand \\
\hline 18 & New Zealand & 18 Turkey \\
\hline 19 & Norway & \\
\hline 20 & Portugal & \\
\hline 21 & Spain & \\
\hline 22 & Sweden & \\
\hline 23 & Switzerland & \\
\hline 24 & United Kingdom & \\
\hline 25 & United States & \\
\hline
\end{tabular}


Table A-1: Country Samples (Continued)

\begin{tabular}{rlllll}
\hline & & \multicolumn{3}{l}{ LDC Countries } & \\
\hline 1 & Albania & 27 & Estonia & 53 & Niger \\
2 & Angola & 28 & Ethiopia & 54 & Nigeria \\
3 & Argentina & 29 & Fiji & 55 & Oman \\
4 & Bahamas & 30 & Gabon & 56 & Pakistan \\
5 & Bahrain & 31 & Ghana & 57 & Panama \\
6 & Bangladesh & 32 & Guatemala & 58 & Papua New Guinea \\
7 & Barbados & 33 & Guinea & 59 & Paraguay \\
8 & Belize & 34 & Haiti & 60 & Romania \\
9 & Benin & 35 & Honduras & 61 & Rwanda \\
10 & Bolivia & 36 & Iran & 62 & Sao Tome \& Principe \\
11 & Botswana & 37 & Jamaica & 63 & Saudi Arabia \\
12 & Bulgaria & 38 & Jordan & 64 & Senegal \\
13 & Burkina Faso & 39 & Kenya & 65 & Sierra Leone \\
14 & Burundi & 40 & Kuwait & 66 & Sri Lanka \\
15 & Cameroon & 41 & Lesotho & 67 & Sudan \\
16 & Cape Verde & 42 & Libya & 68 & Suriname \\
17 & Colombia & 43 & Madagascar & 69 & Swaziland \\
18 & Congo, Republic Of & 44 & Malawi & 70 & Tanzania \\
19 & Costa Rica & 45 & Mali & 71 & Togo \\
20 & Cote D Ivoire & 46 & Malta & 72 & Trinidad and Tobago \\
21 & Croatia & 47 & Mauritius & 73 & Tunisia \\
22 & Djibouti & 48 & Mozambique & 74 & Uganda \\
23 & Dominican Republic & 49 & Myanmar & 75 & Venezuela \\
24 & Ecuador & 50 & Namibia & 76 & Yemen, Republic Of \\
25 & El Salvador & 51 & Nepal & 77 & Zambia \\
26 & Eritrea & 52 & Nicaragua & & \\
\hline
\end{tabular}




\section{Appendix B - Data Definitions and Sources}

\begin{tabular}{|c|c|c|}
\hline Variables & Description & Sources \\
\hline FDI & Foreign Direct Investment & WDI, IFS \\
\hline FPI & Foreign Portfolio Investment & WDI, IFS \\
\hline ODA & Official Development Assistance & WDI, IFS \\
\hline OFI & $\begin{array}{l}\text { Other Non-FDI Financial Investments, } \\
\text { Such As Loans }\end{array}$ & WDI,IFS \\
\hline Domestic Savings & $\begin{array}{l}\text { Gross national savings-consumption of } \\
\text { fixed capital }\end{array}$ & WDI \\
\hline $\mathrm{CA}$ & Current Account Balance & WDI \\
\hline Remittances & Total Workers Remittances By Country & WDI \\
\hline GDP & Gross Domestic Product & WDI \\
\hline Life Expectancy & $\begin{array}{l}\text { Number of years a newborn infant would } \\
\text { live }\end{array}$ & WDI \\
\hline GDP Per Capita & $\begin{array}{l}\text { GDP Per Capita in constant } 2000 \text { US } \\
\text { dollars }\end{array}$ & WDI \\
\hline Education & Secondary education & WDI \\
\hline Work & Size of working population & WDI \\
\hline RPE & Relative Political Extraction & $\begin{array}{l}\text { Arbetman et al. } \\
\text { (forthcoming) }\end{array}$ \\
\hline
\end{tabular}




\section{Appendix C - Statistical Tables OLS Results}

Table C-1: Pooled OLS Regression: Whole Sample _..................................................... 101

Table C-2: Pooled OLS Regression: DC Sample $\ldots 102$

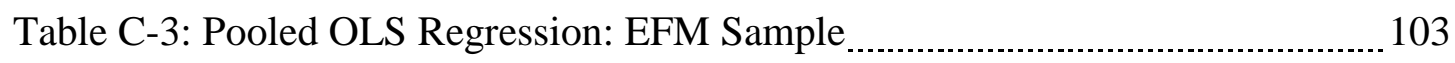

Table C-4: Pooled OLS Regression: LDC Sample _................................................ 104

Table C-5: Pooled OLS Regression: LDC Sample (Life Expectancy)_....................... 105 
Table C-1: Pooled OLS Regression: Whole Sample

\begin{tabular}{|c|c|c|c|c|}
\hline & $\begin{array}{c}\text { Growth } \\
{[1]}\end{array}$ & $\begin{array}{c}\text { Growth } \\
\text { [2] }\end{array}$ & $\begin{array}{c}\text { Growth } \\
{[3]}\end{array}$ & $\begin{array}{c}\text { Growth } \\
{[4]}\end{array}$ \\
\hline gdpcap2000wb & $\begin{array}{l}-0.00004 \\
(2.52)^{* *}\end{array}$ & $\begin{array}{l}-0.00006 \\
(3.67)^{* * *}\end{array}$ & $\begin{array}{l}-0.00004 \\
(2.03)^{* *}\end{array}$ & $\begin{array}{c}-0.00006 \\
(3.36) * * *\end{array}$ \\
\hline LifeExpectancy & $\begin{array}{c}0.07953 \\
(6.69)^{* * * *}\end{array}$ & $\begin{array}{c}0.09478 \\
(8.09)^{* * *}\end{array}$ & $\begin{array}{c}0.07966 \\
(6.69)^{* * * *}\end{array}$ & $\begin{array}{c}0.09652 \\
(8.24)^{* * * *}\end{array}$ \\
\hline FDI_GDP & $\begin{array}{l}2.25023 \\
(2.46)^{* * *}\end{array}$ & $\begin{array}{l}2.82986 \\
(3.05) * * *\end{array}$ & $\begin{array}{l}1.74250 \\
(0.28)\end{array}$ & $\begin{array}{l}7.54925 \\
(1.20)\end{array}$ \\
\hline FPI_GDP & $\begin{array}{l}-2.49078 \\
(2.93)^{* * *}\end{array}$ & $\begin{array}{l}-2.83468 \\
(3.30)^{* * *}\end{array}$ & $\begin{array}{l}-4.93873 \\
(0.81)\end{array}$ & $\begin{array}{l}-9.87281 \\
(1.61)\end{array}$ \\
\hline OFI_GDP & $\begin{array}{l}3.22265 \\
(4.52)^{* * *}\end{array}$ & $\begin{array}{c}3.46474 \\
(4.90)^{* * *}\end{array}$ & $\begin{array}{l}1.92630 \\
(1.17)\end{array}$ & $\begin{array}{l}2.98670 \\
(1.81)^{*}\end{array}$ \\
\hline Remit_GDP & $\begin{array}{l}5.53593 \\
(2.04)^{* * *}\end{array}$ & $\begin{array}{l}5.96020 \\
(2.31)^{* *}\end{array}$ & $\begin{array}{l}5.31536 \\
(0.68)\end{array}$ & $\begin{array}{l}-1.59030 \\
(0.24)\end{array}$ \\
\hline CAofgdp & $\begin{array}{c}-0.04178 \\
(2.98)^{* * * *}\end{array}$ & $\begin{array}{l}0.01260 \\
(1.06)\end{array}$ & $\begin{array}{l}-0.24543 \\
(7.83)^{* * * *}\end{array}$ & $\begin{array}{c}-0.11134 \\
(4.91)^{* * *}\end{array}$ \\
\hline Save_GDP & $\begin{array}{c}8.80891 \\
(8.90)^{* * *}\end{array}$ & & $\begin{array}{c}15.48220 \\
(6.87)^{* * *}\end{array}$ & \\
\hline RPE & $\begin{array}{l}-0.45482 \\
(2.09)^{* *}\end{array}$ & $\begin{array}{l}-0.31511 \\
(1.45)\end{array}$ & $\begin{array}{l}0.54126 \\
(1.62)\end{array}$ & $\begin{array}{l}-0.13825 \\
(0.55)\end{array}$ \\
\hline work & $\begin{array}{l}1.29758 \\
(1.98)^{* *}\end{array}$ & $\begin{array}{l}1.51351 \\
(2.31)^{* *}\end{array}$ & $\begin{array}{l}1.56155 \\
(2.40)^{* *}\end{array}$ & $\begin{array}{c}1.74561 \\
(2.68)^{* * *}\end{array}$ \\
\hline FDI_RPE & & & $\begin{array}{l}0.56860 \\
(0.10)\end{array}$ & $\begin{array}{l}-4.37780 \\
(0.75)\end{array}$ \\
\hline FPI_RPE & & & $\begin{array}{l}2.38275 \\
(0.39)\end{array}$ & $\begin{array}{l}6.92851 \\
(1.14)\end{array}$ \\
\hline OFI_RPE & & & $\begin{array}{l}1.51497 \\
(0.86)\end{array}$ & $\begin{array}{l}0.59949 \\
(0.35)\end{array}$ \\
\hline CA_RPE & & & $\begin{array}{c}0.20534 \\
(7.41)^{* * *}\end{array}$ & $\begin{array}{c}0.13212 \\
(6.44)^{* * *}\end{array}$ \\
\hline Remit_RPE & & & $\begin{array}{l}1.23853 \\
(0.20)\end{array}$ & $\begin{array}{l}7.81873 \\
(1.44)\end{array}$ \\
\hline Save_RPE & & & $\begin{array}{l}-5.39292 \\
(3.28)^{* * *}\end{array}$ & \\
\hline _cons & $\begin{array}{c}-4.78151 \\
(5.69)^{* * *}\end{array}$ & $\begin{array}{c}-4.99081 \\
(6.02)^{* * *}\end{array}$ & $\begin{array}{l}-6.05472 \\
(7.00)^{* * *}\end{array}$ & $\begin{array}{c}-5.38451 \\
(6.44)^{* * *}\end{array}$ \\
\hline$R^{2}$ & 0.08 & 0.05 & 0.11 & 0.07 \\
\hline$N$ & 2,382 & 2,453 & 2,382 & 2,453 \\
\hline
\end{tabular}


Table C-2: Pooled OLS Regression: DC Sample

\begin{tabular}{|c|c|c|c|c|}
\hline & $\begin{array}{c}\text { Growth } \\
{[1]}\end{array}$ & $\begin{array}{c}\text { Growth } \\
\text { [2] }\end{array}$ & $\begin{array}{c}\text { Growth } \\
{[3]}\end{array}$ & $\begin{array}{c}\text { Growth } \\
\text { [4] }\end{array}$ \\
\hline gdpcap2000wb & $\begin{array}{l}0.00001 \\
(0.33)\end{array}$ & $\begin{array}{l}-0.00003 \\
(1.90)^{*}\end{array}$ & $\begin{array}{l}0.00001 \\
(0.44)\end{array}$ & $\begin{array}{l}-0.00004 \\
(1.96)^{*}\end{array}$ \\
\hline LifeExpectancy & $\begin{array}{l}-0.02708 \\
(0.59)\end{array}$ & $\begin{array}{l}-0.08439 \\
(1.67)^{*}\end{array}$ & $\begin{array}{l}-0.03375 \\
(0.73)\end{array}$ & $\begin{array}{l}-0.08738 \\
(1.71)^{*}\end{array}$ \\
\hline FDI_GDP & $\begin{array}{l}0.61195 \\
(1.36)\end{array}$ & $\begin{array}{l}0.79617 \\
(1.59)\end{array}$ & $\begin{array}{l}2.32421 \\
(0.35)\end{array}$ & $\begin{array}{l}6.39481 \\
(0.86)\end{array}$ \\
\hline FPI_GDP & $\begin{array}{l}-0.71748 \\
(1.22)\end{array}$ & $\begin{array}{l}-1.19923 \\
(1.83)^{*}\end{array}$ & $\begin{array}{l}-3.41919 \\
(0.71)\end{array}$ & $\begin{array}{l}-8.09782 \\
(1.52)\end{array}$ \\
\hline OFI_GDP & $\begin{array}{l}1.02379 \\
(1.52)\end{array}$ & $\begin{array}{c}2.31468 \\
(3.14)^{* * *}\end{array}$ & $\begin{array}{l}2.61842 \\
(0.91)\end{array}$ & $\begin{array}{l}1.65163 \\
(0.51)\end{array}$ \\
\hline CAofgdp & $\begin{array}{l}-0.13912 \\
(5.78)^{* * * *}\end{array}$ & $\begin{array}{l}0.04438 \\
(2.13)^{* *}\end{array}$ & $\begin{array}{l}-0.05381 \\
(0.83)\end{array}$ & $\begin{array}{l}0.06466 \\
(1.22)\end{array}$ \\
\hline Save_GDP & $\begin{array}{l}24.55774 \\
(12.12)^{* * *}\end{array}$ & & $\begin{array}{c}28.46706 \\
(5.79) * * *\end{array}$ & \\
\hline RPE & $\begin{array}{c}0.92500 \\
(4.00)^{* * *}\end{array}$ & $\begin{array}{l}0.19827 \\
(0.80)\end{array}$ & $\begin{array}{c}1.28281 \\
(3.21)^{* * *}\end{array}$ & $\begin{array}{l}0.17875 \\
(0.66)\end{array}$ \\
\hline work & $\begin{array}{l}-2.00443 \\
(2.11)^{* *}\end{array}$ & $\begin{array}{l}0.23921 \\
(0.23)\end{array}$ & $\begin{array}{l}-2.23002 \\
(2.32)^{* *}\end{array}$ & $\begin{array}{l}0.24812 \\
(0.24)\end{array}$ \\
\hline second & $\begin{array}{l}0.00024 \\
(1.39)\end{array}$ & $\begin{array}{l}0.00023 \\
(1.18)\end{array}$ & $\begin{array}{l}0.00031 \\
(1.79)^{*}\end{array}$ & $\begin{array}{l}0.00023 \\
(1.20)\end{array}$ \\
\hline FDI_RPE & & & $\begin{array}{l}-1.61981 \\
(0.26)\end{array}$ & $\begin{array}{l}-5.18016 \\
(0.74)\end{array}$ \\
\hline FPI_RPE & & & $\begin{array}{l}2.59392 \\
(0.58)\end{array}$ & $\begin{array}{l}6.74809 \\
(1.35)\end{array}$ \\
\hline OFI_RPE & & & $\begin{array}{l}-1.51319 \\
(0.62)\end{array}$ & $\begin{array}{l}0.87222 \\
(0.32)\end{array}$ \\
\hline CA_RPE & & & $\begin{array}{l}-0.07820 \\
(1.33)\end{array}$ & $\begin{array}{l}-0.01604 \\
(0.39)\end{array}$ \\
\hline Save_RPE & & & $\begin{array}{l}-2.88699 \\
(0.59)\end{array}$ & \\
\hline _cons & $\begin{array}{l}2.17813 \\
(0.61)\end{array}$ & $\begin{array}{l}8.76786 \\
(2.25)^{* *}\end{array}$ & $\begin{array}{l}2.25131 \\
(0.62)\end{array}$ & $\begin{array}{l}9.01794 \\
(2.30)^{* *}\end{array}$ \\
\hline$R^{2}$ & 0.23 & 0.04 & 0.24 & 0.05 \\
\hline$N$ & 626 & 626 & 626 & 626 \\
\hline
\end{tabular}


Table C-3: Pooled OLS Regression: EFM Sample

\begin{tabular}{|c|c|c|c|c|}
\hline & $\begin{array}{c}\text { Growth } \\
{[1]}\end{array}$ & $\begin{array}{c}\text { Growth } \\
\text { [2] }\end{array}$ & $\begin{array}{c}\text { Growth } \\
\text { [3] }\end{array}$ & $\begin{array}{c}\text { Growth } \\
{[4]}\end{array}$ \\
\hline gdpcap2000wb & $\begin{array}{l}-0.00057 \\
(3.58)^{* * *}\end{array}$ & $\begin{array}{l}-0.00085 \\
(5.15)^{* * *}\end{array}$ & $\begin{array}{l}-0.00057 \\
(3.53)^{* * *}\end{array}$ & $\begin{array}{r}-0.00086 \\
(5.25)^{* * *}\end{array}$ \\
\hline LifeExpectancy & $\begin{array}{l}0.22168 \\
(3.83)^{* * * *}\end{array}$ & $\begin{array}{c}0.24603 \\
(4.02)^{* * * *}\end{array}$ & $\begin{array}{c}0.19521 \\
(3.26)^{* * * *}\end{array}$ & $\begin{array}{l}0.20938 \\
(3.31)^{* * *}\end{array}$ \\
\hline FDI_GDP & $\begin{array}{c}18.67494 \\
(2.53)^{* *}\end{array}$ & $\begin{array}{l}19.47142 \\
(2.50)^{* *}\end{array}$ & $\begin{array}{c}-14.78568 \\
(0.80)\end{array}$ & $\begin{array}{c}-31.69781 \\
(1.64)\end{array}$ \\
\hline FPI_GDP & $\begin{array}{c}116.76349 \\
(3.13)^{* * *}\end{array}$ & $\begin{array}{c}114.59602 \\
(2.90)^{* * *}\end{array}$ & $\begin{array}{c}229.71925 \\
(2.01)^{* * *}\end{array}$ & $\begin{array}{c}235.18882 \\
(1.95)^{*}\end{array}$ \\
\hline OFI_GDP & $\begin{array}{l}12.95192 \\
(2.15)^{* *}\end{array}$ & $\begin{array}{c}25.78739 \\
(4.27)^{* * *}\end{array}$ & $\begin{array}{l}24.47208 \\
(1.40)\end{array}$ & $\begin{array}{r}44.50333 \\
(2.56)^{* *}\end{array}$ \\
\hline Remit_GDP & $\begin{array}{c}-22.21298 \\
(2.33)^{* *}\end{array}$ & $\begin{array}{l}-3.00900 \\
(0.31)\end{array}$ & $\begin{array}{c}-17.70470 \\
(1.81)^{*}\end{array}$ & $\begin{array}{c}-5.30226 \\
(0.55)\end{array}$ \\
\hline CAofgdp & $\begin{array}{l}-0.06177 \\
(1.09)\end{array}$ & $\begin{array}{l}0.11568 \\
(2.18)^{* * *}\end{array}$ & $\begin{array}{l}-0.28887 \\
(1.83)^{*}\end{array}$ & $\begin{array}{c}0.06430 \\
(0.48)\end{array}$ \\
\hline Save_GDP & $\begin{array}{c}20.91544 \\
(6.61)^{* * *}\end{array}$ & & $\begin{array}{c}33.20915 \\
(4.66) * * *\end{array}$ & \\
\hline RPE & $\begin{array}{l}0.37477 \\
(0.61)\end{array}$ & $\begin{array}{l}-0.57131 \\
(0.90)\end{array}$ & $\begin{array}{l}1.04569 \\
(1.01)\end{array}$ & $\begin{array}{r}-1.74662 \\
(2.15)^{* *}\end{array}$ \\
\hline second & $\begin{array}{l}-0.00115 \\
(0.98)\end{array}$ & $\begin{array}{l}-0.00033 \\
(0.26)\end{array}$ & $\begin{array}{l}-0.00216 \\
(1.77)^{*}\end{array}$ & $\begin{array}{c}-0.00144 \\
(1.12)\end{array}$ \\
\hline work & $\begin{array}{l}-5.38731 \\
(1.84)^{*}\end{array}$ & $\begin{array}{l}1.94080 \\
(0.68)\end{array}$ & $\begin{array}{l}-6.18354 \\
(2.10)^{* *}\end{array}$ & $\begin{array}{c}0.48306 \\
(0.17)\end{array}$ \\
\hline FDI_RPE & & & $\begin{array}{c}59.98403 \\
(2.05) * *\end{array}$ & $\begin{array}{r}89.37525 \\
(2.96)^{* * *}\end{array}$ \\
\hline FPI_RPE & & & $\begin{array}{c}-143.64631 \\
(1.12)\end{array}$ & $\begin{array}{c}-157.76834 \\
(1.16)\end{array}$ \\
\hline OFI_RPE & & & $\begin{array}{l}-8.30587 \\
(0.48)\end{array}$ & $\begin{array}{c}-17.67217 \\
(1.05)\end{array}$ \\
\hline CA_RPE & & & $\begin{array}{l}0.24968 \\
(1.55)\end{array}$ & $\begin{array}{c}0.07815 \\
(0.57)\end{array}$ \\
\hline Save_RPE & & & $\begin{array}{c}-13.85955 \\
(2.07)^{* *}\end{array}$ & \\
\hline _cons & $\begin{array}{c}-10.48261 \\
(2.60)^{* * *}\end{array}$ & $\begin{array}{c}-12.57322 \\
(2.95)^{* * *}\end{array}$ & $\begin{array}{l}-8.61913 \\
(1.96)^{*}\end{array}$ & $\begin{array}{c}-7.81642 \\
(1.68)^{*}\end{array}$ \\
\hline$R^{2}$ & 0.28 & 0.19 & 0.30 & 0.22 \\
\hline$N$ & 363 & 363 & 363 & 363 \\
\hline
\end{tabular}

$* p<0.1 ; * * p<0.05 ; * * * p<0.01$ 
Table C-4: Pooled OLS Regression: LDC Sample

\begin{tabular}{|c|c|c|c|c|}
\hline & $\begin{array}{c}\text { Growth } \\
{[1]}\end{array}$ & $\begin{array}{c}\text { Growth } \\
{[2]}\end{array}$ & $\begin{array}{c}\text { Growth } \\
\text { [3] }\end{array}$ & $\begin{array}{c}\text { Growth } \\
{[4]}\end{array}$ \\
\hline gdpcap2000wb & $\begin{array}{l}-0.00018 \\
(3.06)^{* * *}\end{array}$ & $\begin{array}{l}-0.00018 \\
(3.00)^{* * *}\end{array}$ & $\begin{array}{l}-0.00008 \\
(1.28)\end{array}$ & $\begin{array}{c}-0.00008 \\
(1.37)\end{array}$ \\
\hline LifeExpectancy & $\begin{array}{c}0.07630 \\
(3.80)^{* * *}\end{array}$ & $\begin{array}{l}0.06236 \\
(3.25)^{* * *}\end{array}$ & $\begin{array}{l}0.07172 \\
(3.60)^{* * *}\end{array}$ & $\begin{array}{l}0.05610 \\
(2.95)^{* * *}\end{array}$ \\
\hline FDI_GDP & $\begin{array}{c}11.46807 \\
(3.06)^{* * *}\end{array}$ & $\begin{array}{c}16.60405 \\
(4.60)^{* * * *}\end{array}$ & $\begin{array}{l}17.13399 \\
(1.74)^{*}\end{array}$ & $\begin{array}{r}26.20448 \\
(2.79)^{* * * *}\end{array}$ \\
\hline FPI_GDP & $\begin{array}{l}40.16264 \\
(1.13)\end{array}$ & $\begin{array}{l}30.10456 \\
(0.85)\end{array}$ & $\begin{array}{c}-176.11730 \\
(1.40)\end{array}$ & $\begin{array}{c}-171.30986 \\
(1.37)\end{array}$ \\
\hline OFI_GDP & $\begin{array}{l}2.91510 \\
(3.22)^{* * *}\end{array}$ & $\begin{array}{l}2.77122 \\
(3.14) * * *\end{array}$ & $\begin{array}{l}1.43968 \\
(0.75)\end{array}$ & $\begin{array}{l}1.23124 \\
(0.64)\end{array}$ \\
\hline Remit_GDP & $\begin{array}{l}7.87525 \\
(2.35)^{* *}\end{array}$ & $\begin{array}{l}7.23045 \\
(2.31)^{* *}\end{array}$ & $\begin{array}{l}9.86109 \\
(2.96)^{* * *}\end{array}$ & $\begin{array}{l}9.23173 \\
(2.96) * * *\end{array}$ \\
\hline ODA_GDP & $\begin{array}{c}0.00000 \\
(4.87)^{* * *}\end{array}$ & $\begin{array}{l}0.00000 \\
(3.40)^{* * *}\end{array}$ & $\begin{array}{c}0.00000 \\
(5.09)^{* * *}\end{array}$ & $\begin{array}{l}0.00000 \\
(3.88)^{* * *}\end{array}$ \\
\hline CAofgdp & $\begin{array}{l}0.00272 \\
(0.16)\end{array}$ & $\begin{array}{l}0.02881 \\
(1.94)^{*}\end{array}$ & $\begin{array}{l}-0.15156 \\
(4.96)^{* * * *}\end{array}$ & $\begin{array}{r}-0.12000 \\
(4.22)^{* * *}\end{array}$ \\
\hline Save_GDP & $\begin{array}{c}5.32450 \\
(4.38)^{* * *}\end{array}$ & & $\begin{array}{c}4.89651 \\
(4.06)^{* * *}\end{array}$ & \\
\hline RPE & $\begin{array}{l}-0.28662 \\
(1.05)\end{array}$ & $\begin{array}{l}-0.12027 \\
(0.45)\end{array}$ & $\begin{array}{l}0.05320 \\
(0.17)\end{array}$ & $\begin{array}{l}0.27691 \\
(0.93)\end{array}$ \\
\hline work & $\begin{array}{l}-0.40028 \\
(0.49)\end{array}$ & $\begin{array}{l}0.40232 \\
(0.52)\end{array}$ & $\begin{array}{l}-0.08532 \\
(0.11)\end{array}$ & $\begin{array}{c}0.65088 \\
(0.84)\end{array}$ \\
\hline second & $\begin{array}{l}0.00062 \\
(1.09)\end{array}$ & $\begin{array}{l}0.00091 \\
(1.62)\end{array}$ & $\begin{array}{l}0.00066 \\
(1.18)\end{array}$ & $\begin{array}{c}0.00101 \\
(1.82)^{*}\end{array}$ \\
\hline FDI_RPE & & & $\begin{array}{l}-4.78369 \\
(0.60)\end{array}$ & $\begin{array}{c}-8.29363 \\
(1.07)\end{array}$ \\
\hline FPI_RPE & & & $\begin{array}{c}199.84182 \\
(1.76)^{*}\end{array}$ & $\begin{array}{c}188.90102 \\
(1.67)^{*}\end{array}$ \\
\hline OFI_RPE & & & $\begin{array}{l}1.56867 \\
(0.70)\end{array}$ & $\begin{array}{l}1.51776 \\
(0.69)\end{array}$ \\
\hline CA_RPE & & & $\begin{array}{c}0.15421 \\
(6.16)^{* * *}\end{array}$ & $\begin{array}{l}0.14874 \\
(6.13)^{* * *}\end{array}$ \\
\hline _cons & $\begin{array}{c}-4.37090 \\
(3.74)^{* * *}\end{array}$ & $\begin{array}{c}-3.61689 \\
(3.22)^{* * *}\end{array}$ & $\begin{array}{c}-4.83553 \\
(4.16)^{* * *}\end{array}$ & $\begin{array}{r}-4.05544 \\
(3.64)^{* * *}\end{array}$ \\
\hline$R^{2}$ & 0.08 & 0.06 & 0.10 & 0.08 \\
\hline$N$ & 1,588 & 1,659 & 1,588 & 1,659 \\
\hline
\end{tabular}

$* p<0.1 ; * * p<0.05 ; * * * p<0.01$ 
Table C-5: Pooled OLS Regression: LDC Sample (Life Expectancy)

\begin{tabular}{|c|c|c|c|c|}
\hline & $\begin{array}{c}\text { Life } \\
\text { Expectancy } \\
{[1]}\end{array}$ & $\begin{array}{c}\text { Life } \\
\text { Expectancy } \\
{[2]}\end{array}$ & $\begin{array}{c}\text { Life } \\
\text { Expectancy } \\
\text { [3] }\end{array}$ & $\begin{array}{c}\text { Life } \\
\text { Expectancy } \\
{[4]}\end{array}$ \\
\hline FDI_GDP & $\begin{array}{r}15.08706 \\
(3.13)^{* * *}\end{array}$ & $\begin{array}{r}11.38243 \\
(2.39)^{* *}\end{array}$ & $\begin{array}{r}53.22538 \\
(4.35)^{* * *}\end{array}$ & $\begin{array}{r}34.05114 \\
(2.80)^{* * *}\end{array}$ \\
\hline FPI_GDP & $\begin{array}{r}14.23007 \\
(0.33)\end{array}$ & $\begin{array}{r}15.67960 \\
(0.35)\end{array}$ & $\begin{array}{r}192.07174 \\
(1.54)\end{array}$ & $\begin{array}{r}171.47501 \\
(1.34)\end{array}$ \\
\hline OFI_GDP & $\begin{array}{r}-1.61101 \\
(1.36)\end{array}$ & $\begin{array}{r}-0.55965 \\
(0.47)\end{array}$ & $\begin{array}{r}-4.81435 \\
(1.92)^{*}\end{array}$ & $\begin{array}{r}-4.24313 \\
(1.64)\end{array}$ \\
\hline Remit_GDP & $\begin{array}{l}55.13337 \\
(13.54)^{* * * *}\end{array}$ & $\begin{array}{l}53.11706 \\
(13.49)^{* * * *}\end{array}$ & $\begin{array}{l}55.37664 \\
(13.63)^{* * * *}\end{array}$ & $\begin{array}{l}53.10994 \\
(13.48)^{* * * *}\end{array}$ \\
\hline ODA_GDP & $\begin{array}{l}-0.00000 \\
(11.41)^{* * *}\end{array}$ & $\begin{array}{r}-0.00000 \\
(7.37)^{* * *}\end{array}$ & $\begin{array}{l}-0.00000 \\
(11.43)^{* * *}\end{array}$ & $\begin{array}{r}-0.00000 \\
(7.44)^{* * *}\end{array}$ \\
\hline CAofgdp & $\begin{array}{r}0.02622 \\
(1.29)\end{array}$ & $\begin{array}{l}0.05623 \\
(3.55)^{* * *}\end{array}$ & $\begin{array}{r}0.02454 \\
(0.93)\end{array}$ & $\begin{array}{r}0.04602 \\
(2.02)^{* *}\end{array}$ \\
\hline Save_GDP & $\begin{array}{r}3.02096 \\
(1.93)^{*}\end{array}$ & & $\begin{array}{r}2.86408 \\
(1.83)^{*}\end{array}$ & \\
\hline RPE & $\begin{array}{r}-0.80230 \\
(2.27)^{* *}\end{array}$ & $\begin{array}{r}-0.34845 \\
(0.98)\end{array}$ & $\begin{array}{r}-0.22868 \\
(0.58)\end{array}$ & $\begin{array}{r}0.01327 \\
(0.03)\end{array}$ \\
\hline work & $\begin{array}{r}1.65881 \\
(1.56)\end{array}$ & $\begin{array}{r}-1.19759 \\
(1.14)\end{array}$ & $\begin{array}{r}1.39612 \\
(1.30)\end{array}$ & $\begin{array}{r}-1.38973 \\
(1.32)\end{array}$ \\
\hline second & $\begin{array}{r}0.01921 \\
(34.92)^{* * *}\end{array}$ & $\begin{array}{r}0.02052 \\
(37.69)^{* * *}\end{array}$ & $\begin{array}{r}0.01906 \\
(34.58)^{* * *}\end{array}$ & $\begin{array}{r}0.02039 \\
(37.23)^{* * *}\end{array}$ \\
\hline FDI_RPE & & & $\begin{array}{r}-32.55042 \\
(3.28)^{* * * *}\end{array}$ & $\begin{array}{r}-19.21733 \\
(1.90)^{*}\end{array}$ \\
\hline FPI_RPE & & & $\begin{array}{r}-162.41629 \\
(1.45)\end{array}$ & $\begin{array}{r}-146.08702 \\
(1.26)\end{array}$ \\
\hline OFI_RPE & & & $\begin{array}{r}3.82077 \\
(1.30)\end{array}$ & $\begin{array}{r}4.59964 \\
(1.54)\end{array}$ \\
\hline CA_RPE & & & $\begin{array}{r}0.01016 \\
(0.43)\end{array}$ & $\begin{array}{r}0.01850 \\
(0.77)\end{array}$ \\
\hline _cons & $\begin{array}{l}51.22304 \\
(67.01)^{* * *}\end{array}$ & $\begin{array}{l}51.27926 \\
(67.69)^{* * *}\end{array}$ & $\begin{array}{l}50.80316 \\
(64.77)^{* * *}\end{array}$ & $\begin{array}{l}51.03564 \\
(65.50) * * *\end{array}$ \\
\hline $\begin{array}{l}R^{2} \\
N\end{array}$ & $\begin{array}{r}0.59 \\
1,599\end{array}$ & $\begin{array}{r}0.56 \\
1,679\end{array}$ & $\begin{array}{r}0.59 \\
1,599\end{array}$ & $\begin{array}{r}0.56 \\
1,679\end{array}$ \\
\hline
\end{tabular}




\section{Appendix D - Statistical Tables Fixed Effects Results}

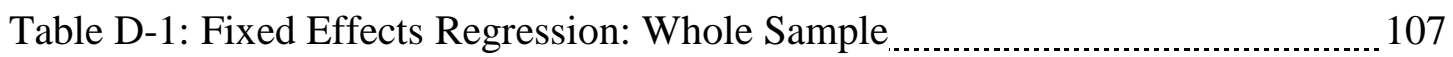

Table D-2: Fixed Effects Regression: DC Sample

Table D-3: Fixed Effects Regression: EFM Sample $\ldots \ldots \ldots$

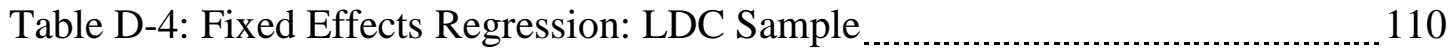

Table D-5: Fixed Effects Regression: LDC Sample (Life Expectancy) ...................... 111 
Table D-1: Panel Data Analysis using Fixed-Effects: Whole Sample

\begin{tabular}{|c|c|c|c|c|}
\hline & $\begin{array}{c}\text { Growth } \\
{[1]}\end{array}$ & $\begin{array}{c}\text { Growth } \\
\text { [2] }\end{array}$ & $\begin{array}{c}\text { Growth } \\
\text { [3] }\end{array}$ & $\begin{array}{c}\text { Growth } \\
{[4]}\end{array}$ \\
\hline gdpcap2000wb & $\begin{array}{l}-0.00008 \\
(1.21)\end{array}$ & $\begin{array}{l}-0.00010 \\
(1.45)\end{array}$ & $\begin{array}{l}-0.00009 \\
(1.23)\end{array}$ & $\begin{array}{l}-0.00010 \\
(1.46)\end{array}$ \\
\hline LifeExpectancy & $\begin{array}{c}0.26026 \\
(7.11)^{* * *}\end{array}$ & $\begin{array}{c}0.26657 \\
(7.35)^{* * *}\end{array}$ & $\begin{array}{c}0.26855 \\
(7.15)^{* * * *}\end{array}$ & $\begin{array}{c}0.26658 \\
(7.25)^{* * *}\end{array}$ \\
\hline FDI_GDP & $\begin{array}{l}4.02785 \\
(2.31)^{* *}\end{array}$ & $\begin{array}{l}5.08487 \\
(2.91)^{* * *}\end{array}$ & $\begin{array}{l}5.82062 \\
(0.82)\end{array}$ & $\begin{array}{l}11.34628 \\
(1.63)\end{array}$ \\
\hline FPI_GDP & $\begin{array}{l}-1.15881 \\
(1.03)\end{array}$ & $\begin{array}{l}-0.97694 \\
(0.87)\end{array}$ & $\begin{array}{l}-2.53381 \\
(0.40)\end{array}$ & $\begin{array}{l}-6.29965 \\
(1.00)\end{array}$ \\
\hline OFI_GDP & $\begin{array}{c}2.69073 \\
(3.70) * * *\end{array}$ & $\begin{array}{c}2.93455 \\
(4.09)^{* * *}\end{array}$ & $\begin{array}{l}1.42563 \\
(0.84)\end{array}$ & $\begin{array}{l}1.65858 \\
(0.99)\end{array}$ \\
\hline Remit_GDP & $\begin{array}{l}10.22038 \\
(1.85)^{*}\end{array}$ & $\begin{array}{c}18.12155 \\
(3.71)^{* * *}\end{array}$ & $\begin{array}{c}-17.38583 \\
(1.43)\end{array}$ & $\begin{array}{l}-2.08623 \\
(0.21)\end{array}$ \\
\hline CAofgdp & $\begin{array}{l}-0.01604 \\
(0.93)\end{array}$ & $\begin{array}{l}0.02802 \\
(1.78)^{*}\end{array}$ & $\begin{array}{c}-0.13209 \\
(3.28)^{* * * *}\end{array}$ & $\begin{array}{l}-0.07219 \\
(2.36)^{* *}\end{array}$ \\
\hline Save_GDP & $\begin{array}{l}8.59895 \\
(7.08) * * *\end{array}$ & & $\begin{array}{l}7.94896 \\
(2.66)^{* * * *}\end{array}$ & \\
\hline RPE & $\begin{array}{l}-0.27464 \\
(0.71)\end{array}$ & $\begin{array}{l}-0.34889 \\
(0.92)\end{array}$ & $\begin{array}{l}-0.11399 \\
(0.23)\end{array}$ & $\begin{array}{l}-0.07914 \\
(0.19)\end{array}$ \\
\hline work & $\begin{array}{l}0.00112 \\
(0.00)\end{array}$ & $\begin{array}{l}-0.75872 \\
(0.33)\end{array}$ & $\begin{array}{l}0.48513 \\
(0.21)\end{array}$ & $\begin{array}{l}-0.85110 \\
(0.37)\end{array}$ \\
\hline FDI_RPE & & & $\begin{array}{l}-1.30930 \\
(0.21)\end{array}$ & $\begin{array}{l}-5.48917 \\
(0.88)\end{array}$ \\
\hline FPI_RPE & & & $\begin{array}{l}1.25853 \\
(0.20)\end{array}$ & $\begin{array}{l}5.17626 \\
(0.81)\end{array}$ \\
\hline OFI_RPE & & & $\begin{array}{l}1.57162 \\
(0.86)\end{array}$ & $\begin{array}{l}1.58620 \\
(0.88)\end{array}$ \\
\hline CA_RPE & & & $\begin{array}{c}0.11453 \\
(3.39)^{* * * *}\end{array}$ & $\begin{array}{c}0.10140 \\
(3.93)^{* * *}\end{array}$ \\
\hline Remit_RPE & & & $\begin{array}{c}24.13755 \\
(2.49)^{* *}\end{array}$ & $\begin{array}{c}20.47402 \\
(2.36)^{* *}\end{array}$ \\
\hline Save_RPE & & & $\begin{array}{l}0.47247 \\
(0.21)\end{array}$ & \\
\hline _cons & $\begin{array}{r}-15.79030 \\
(6.18)^{* * *}\end{array}$ & $\begin{array}{r}-14.86901 \\
(5.91)^{* * *}\end{array}$ & $\begin{array}{r}-16.69026 \\
(6.43) * * *\end{array}$ & $\begin{array}{r}-15.10031 \\
(5.99)^{* * * *}\end{array}$ \\
\hline$R^{2}$ & 0.07 & 0.05 & 0.08 & 0.06 \\
\hline$N$ & 2,382 & 2,453 & 2,382 & 2,453 \\
\hline
\end{tabular}


Table D-2: Panel Data Analysis using Fixed-Effects: DC Sample

\begin{tabular}{|c|c|c|c|c|}
\hline & $\begin{array}{c}\text { Growth } \\
{[1]}\end{array}$ & $\begin{array}{c}\text { Growth } \\
{[2]}\end{array}$ & $\begin{array}{c}\text { Growth } \\
{[3]}\end{array}$ & $\begin{array}{c}\text { Growth } \\
{[4]}\end{array}$ \\
\hline gdpcap2000wb & $\begin{array}{l}0.00001 \\
(0.29)\end{array}$ & $\begin{array}{l}0.00003 \\
(0.59)\end{array}$ & $\begin{array}{l}0.00007 \\
(1.43)\end{array}$ & $\begin{array}{l}0.00006 \\
(1.26)\end{array}$ \\
\hline LifeExpectancy & $\begin{array}{l}0.07713 \\
(0.98)\end{array}$ & $\begin{array}{l}-0.09573 \\
(1.17)\end{array}$ & $\begin{array}{l}0.01170 \\
(0.15)\end{array}$ & $\begin{array}{l}-0.15905 \\
(1.88)^{*}\end{array}$ \\
\hline FDI_GDP & $\begin{array}{l}2.39125 \\
(2.73)^{* * *}\end{array}$ & $\begin{array}{l}2.49579 \\
(2.67)^{* * *}\end{array}$ & $\begin{array}{l}0.56012 \\
(0.08)\end{array}$ & $\begin{array}{l}2.01590 \\
(0.25)\end{array}$ \\
\hline FPI_GDP & $\begin{array}{l}-0.54937 \\
(0.80)\end{array}$ & $\begin{array}{l}-0.42745 \\
(0.59)\end{array}$ & $\begin{array}{l}-4.55444 \\
(0.86)\end{array}$ & $\begin{array}{l}-5.55816 \\
(0.97)\end{array}$ \\
\hline OFI_GDP & $\begin{array}{l}1.32179 \\
(1.85)^{*}\end{array}$ & $\begin{array}{l}1.66545 \\
(2.18)^{* *}\end{array}$ & $\begin{array}{l}8.09304 \\
(2.66)^{* * *}\end{array}$ & $\begin{array}{l}8.53305 \\
(2.59)^{* * *}\end{array}$ \\
\hline CAofgdp & $\begin{array}{c}-0.14094 \\
(4.47)^{* * * *}\end{array}$ & $\begin{array}{l}0.04182 \\
(1.59)\end{array}$ & $\begin{array}{l}0.00687 \\
(0.09)\end{array}$ & $\begin{array}{c}0.17770 \\
(2.70) * * *\end{array}$ \\
\hline Save_GDP & $\begin{array}{c}27.96035 \\
(9.28) * * *\end{array}$ & & $\begin{array}{c}41.10812 \\
(6.06) * * *\end{array}$ & \\
\hline RPE & $\begin{array}{l}0.27412 \\
(0.63)\end{array}$ & $\begin{array}{l}0.51151 \\
(1.11)\end{array}$ & $\begin{array}{l}1.19327 \\
(1.90)^{*}\end{array}$ & $\begin{array}{l}0.73046 \\
(1.49)\end{array}$ \\
\hline work & $\begin{array}{c}-9.50995 \\
(3.77)^{* * * *}\end{array}$ & $\begin{array}{l}-2.10682 \\
(0.82)\end{array}$ & $\begin{array}{r}-11.20098 \\
(4.39)^{* * *}\end{array}$ & $\begin{array}{l}-3.03697 \\
(1.15)\end{array}$ \\
\hline second & $\begin{array}{l}0.00054 \\
(1.37)\end{array}$ & $\begin{array}{l}0.00090 \\
(2.17)^{* *}\end{array}$ & $\begin{array}{l}0.00056 \\
(1.45)\end{array}$ & $\begin{array}{l}0.00098 \\
(2.34)^{* *}\end{array}$ \\
\hline FDI_RPE & & & $\begin{array}{l}1.76386 \\
(0.26)\end{array}$ & $\begin{array}{l}0.68981 \\
(0.10)\end{array}$ \\
\hline FPI_RPE & & & $\begin{array}{l}3.49808 \\
(0.69)\end{array}$ & $\begin{array}{l}4.62198 \\
(0.85)\end{array}$ \\
\hline OFI_RPE & & & $\begin{array}{l}-6.04996 \\
(2.35)^{* *}\end{array}$ & $\begin{array}{l}-5.99456 \\
(2.15)^{* *}\end{array}$ \\
\hline CA_RPE & & & $\begin{array}{l}-0.12120 \\
(1.77)^{*}\end{array}$ & $\begin{array}{l}-0.11811 \\
(2.43)^{* *}\end{array}$ \\
\hline Save_RPE & & & $\begin{array}{c}-10.99056 \\
(1.72)^{*}\end{array}$ & \\
\hline _cons & $\begin{array}{l}-1.27154 \\
(0.22)\end{array}$ & $\begin{array}{l}8.71237 \\
(1.46)\end{array}$ & $\begin{array}{l}2.55403 \\
(0.44)\end{array}$ & $\begin{array}{c}13.12700 \\
(2.14)^{* *}\end{array}$ \\
\hline$R^{2}$ & 0.16 & 0.03 & 0.20 & 0.05 \\
\hline$N$ & 626 & 626 & 626 & 626 \\
\hline
\end{tabular}


Table D-3: Panel Data Analysis using Fixed-Effects: EFM Sample

\begin{tabular}{|c|c|c|c|c|}
\hline & $\begin{array}{c}\text { Growth } \\
{[1]}\end{array}$ & $\begin{array}{c}\text { Growth } \\
\text { [2] }\end{array}$ & $\begin{array}{c}\text { Growth } \\
{[3]}\end{array}$ & $\begin{array}{c}\text { Growth } \\
{[4]}\end{array}$ \\
\hline gdpcap2000wb & $\begin{array}{l}-0.00058 \\
(1.85)^{*}\end{array}$ & $\begin{array}{l}-0.00042 \\
(1.23)\end{array}$ & $\begin{array}{l}-0.00061 \\
(1.60)\end{array}$ & $\begin{array}{l}-0.00034 \\
(0.78)\end{array}$ \\
\hline LifeExpectancy & $\begin{array}{c}0.25221 \\
(3.26)^{* * *}\end{array}$ & $\begin{array}{l}0.20059 \\
(3.32)^{* * * *}\end{array}$ & $\begin{array}{l}0.22082 \\
(2.48)^{* *}\end{array}$ & $\begin{array}{l}0.14427 \\
(1.66)^{*}\end{array}$ \\
\hline FDI_GDP & $\begin{array}{l}14.97950 \\
(1.41)\end{array}$ & $\begin{array}{l}14.90142 \\
(1.14)\end{array}$ & $\begin{array}{c}-15.43208 \\
(0.59)\end{array}$ & $\begin{array}{c}-31.52467 \\
(1.09)\end{array}$ \\
\hline FPI_GDP & $\begin{array}{c}95.10916 \\
(3.45)^{* * *}\end{array}$ & $\begin{array}{r}100.71017 \\
(3.38)^{* * *}\end{array}$ & $\begin{array}{c}168.87398 \\
(2.14)^{* *}\end{array}$ & $\begin{array}{c}149.30918 \\
(1.78)^{*}\end{array}$ \\
\hline OFI_GDP & $\begin{array}{l}16.37669 \\
(1.50)\end{array}$ & $\begin{array}{c}23.37150 \\
(2.25)^{* *}\end{array}$ & $\begin{array}{l}31.59750 \\
(1.06)\end{array}$ & $\begin{array}{c}38.70985 \\
(1.34)\end{array}$ \\
\hline Remit_GDP & $\begin{array}{l}-0.04144 \\
(0.00)\end{array}$ & $\begin{array}{c}21.42806 \\
(3.29)^{* * *}\end{array}$ & $\begin{array}{l}1.73610 \\
(0.21)\end{array}$ & $\begin{array}{r}20.71300 \\
(3.01)^{* * *}\end{array}$ \\
\hline CAofgdp & $\begin{array}{l}-0.11307 \\
(0.96)\end{array}$ & $\begin{array}{l}0.00618 \\
(0.05)\end{array}$ & $\begin{array}{l}-0.24080 \\
(1.13)\end{array}$ & $\begin{array}{l}-0.17574 \\
(0.88)\end{array}$ \\
\hline Save_GDP & $\begin{array}{c}20.32238 \\
(6.05)^{* * *}\end{array}$ & & $\begin{array}{c}19.32976 \\
(4.81)^{* * *}\end{array}$ & \\
\hline RPE & $\begin{array}{l}0.32941 \\
(0.24)\end{array}$ & $\begin{array}{l}-0.60211 \\
(0.49)\end{array}$ & $\begin{array}{l}-0.36391 \\
(0.20)\end{array}$ & $\begin{array}{l}-1.56013 \\
(0.88)\end{array}$ \\
\hline second & $\begin{array}{l}0.00003 \\
(0.01)\end{array}$ & $\begin{array}{l}0.00147 \\
(0.44)\end{array}$ & $\begin{array}{l}-0.00013 \\
(0.03)\end{array}$ & $\begin{array}{l}0.00129 \\
(0.36)\end{array}$ \\
\hline work & $\begin{array}{l}1.45709 \\
(0.35)\end{array}$ & $\begin{array}{l}8.61197 \\
(2.06)^{* *}\end{array}$ & $\begin{array}{l}1.79724 \\
(0.35)\end{array}$ & $\begin{array}{l}7.10891 \\
(1.21)\end{array}$ \\
\hline FDI_RPE & & & $\begin{array}{l}53.03588 \\
(1.07)\end{array}$ & $\begin{array}{l}79.06992 \\
(1.49)\end{array}$ \\
\hline FPI_RPE & & & $\begin{array}{c}-93.85321 \\
(0.91)\end{array}$ & $\begin{array}{c}-67.79108 \\
(0.63)\end{array}$ \\
\hline OFI_RPE & & & $\begin{array}{c}-12.10665 \\
(0.60)\end{array}$ & $\begin{array}{c}-12.71802 \\
(0.61)\end{array}$ \\
\hline CA_RPE & & & $\begin{array}{l}0.14952 \\
(1.08)\end{array}$ & $\begin{array}{l}0.21066 \\
(1.65)^{*}\end{array}$ \\
\hline _cons & $\begin{array}{c}-17.32751 \\
(2.51)^{* *}\end{array}$ & $\begin{array}{r}-15.90319 \\
(2.58)^{* * *}\end{array}$ & $\begin{array}{c}-14.78497 \\
(1.73)^{*}\end{array}$ & $\begin{array}{c}-10.90925 \\
(1.32)\end{array}$ \\
\hline$N$ & 363 & 363 & 363 & 363 \\
\hline
\end{tabular}


Table D-4: Panel Data Analysis using Fixed-Effects: LDC Sample

\begin{tabular}{|c|c|c|c|c|}
\hline & $\begin{array}{c}\text { Growth } \\
{[1]}\end{array}$ & $\begin{array}{c}\text { Growth } \\
\text { [2] }\end{array}$ & $\begin{array}{c}\text { Growth } \\
\text { [3] }\end{array}$ & $\begin{array}{c}\text { Growth } \\
{[4]}\end{array}$ \\
\hline gdpcap2000wb & $\begin{array}{l}0.00030 \\
(1.25)\end{array}$ & $\begin{array}{l}0.00025 \\
(1.04)\end{array}$ & $\begin{array}{l}0.00026 \\
(1.08)\end{array}$ & $\begin{array}{c}0.00022 \\
(0.94)\end{array}$ \\
\hline LifeExpectancy & $\begin{array}{c}0.28017 \\
(5.57)^{* * *}\end{array}$ & $\begin{array}{c}0.28733 \\
(5.92) * * *\end{array}$ & $\begin{array}{c}0.26634 \\
(5.21)^{* * *}\end{array}$ & $\begin{array}{l}0.26734 \\
(5.46)^{* * * *}\end{array}$ \\
\hline FDI_GDP & $\begin{array}{l}5.62386 \\
(1.30)\end{array}$ & $\begin{array}{l}9.50285 \\
(2.28)^{* *}\end{array}$ & $\begin{array}{l}12.68823 \\
(1.15)\end{array}$ & $\begin{array}{c}20.08505 \\
(1.95)^{*}\end{array}$ \\
\hline FPI_GDP & $\begin{array}{l}17.73707 \\
(0.45)\end{array}$ & $\begin{array}{l}14.62539 \\
(0.37)\end{array}$ & $\begin{array}{c}-85.49691 \\
(0.62)\end{array}$ & $\begin{array}{c}-115.23218 \\
(0.84)\end{array}$ \\
\hline OFI_GDP_ & $\begin{array}{l}2.71082 \\
(2.92)^{* * *}\end{array}$ & $\begin{array}{l}2.77014 \\
(3.07)^{* * *}\end{array}$ & $\begin{array}{l}0.78562 \\
(0.38)\end{array}$ & $\begin{array}{c}0.30087 \\
(0.15)\end{array}$ \\
\hline Remit_GDP & $\begin{array}{l}6.94613 \\
(1.00)\end{array}$ & $\begin{array}{l}12.47032 \\
(2.07)^{* *}\end{array}$ & $\begin{array}{c}-15.02669 \\
(1.00)\end{array}$ & $\begin{array}{c}-3.66185 \\
(0.31)\end{array}$ \\
\hline ODA_GDP & $\begin{array}{l}0.00000 \\
(2.33)^{* *}\end{array}$ & $\begin{array}{l}0.00000 \\
(1.51)\end{array}$ & $\begin{array}{l}0.00000 \\
(2.23)^{* *}\end{array}$ & $\begin{array}{c}0.00000 \\
(1.72)^{*}\end{array}$ \\
\hline CAofgdp & $\begin{array}{l}0.00143 \\
(0.07)\end{array}$ & $\begin{array}{l}0.03734 \\
(1.92)^{*}\end{array}$ & $\begin{array}{l}-0.10185 \\
(2.05)^{* *}\end{array}$ & $\begin{array}{r}-0.08004 \\
(2.17)^{* *}\end{array}$ \\
\hline Save_GDP & $\begin{array}{c}6.48103 \\
(4.45)^{* * *}\end{array}$ & & $\begin{array}{l}2.08314 \\
(0.57)\end{array}$ & \\
\hline RPE & $\begin{array}{l}-0.39849 \\
(0.78)\end{array}$ & $\begin{array}{l}-0.37307 \\
(0.76)\end{array}$ & $\begin{array}{l}-0.23141 \\
(0.35)\end{array}$ & $\begin{array}{c}0.21246 \\
(0.39)\end{array}$ \\
\hline work & $\begin{array}{l}-0.38828 \\
(0.13)\end{array}$ & $\begin{array}{l}-1.74544 \\
(0.59)\end{array}$ & $\begin{array}{l}-0.16579 \\
(0.05)\end{array}$ & $\begin{array}{c}-2.21994 \\
(0.74)\end{array}$ \\
\hline second & $\begin{array}{l}0.00002 \\
(0.01)\end{array}$ & $\begin{array}{l}-0.00027 \\
(0.20)\end{array}$ & $\begin{array}{l}0.00056 \\
(0.40)\end{array}$ & $\begin{array}{c}0.00018 \\
(0.13)\end{array}$ \\
\hline FDI_RPE & & & $\begin{array}{l}-5.14147 \\
(0.58)\end{array}$ & $\begin{array}{c}-9.01478 \\
(1.07)\end{array}$ \\
\hline FPI_RPE & & & $\begin{array}{l}97.35552 \\
(0.79)\end{array}$ & $\begin{array}{c}126.33347 \\
(1.03)\end{array}$ \\
\hline OFI_RPE & & & $\begin{array}{l}2.39882 \\
(0.99)\end{array}$ & $\begin{array}{c}2.97437 \\
(1.26)\end{array}$ \\
\hline CA_RPE & & & $\begin{array}{l}0.10228 \\
(2.50)^{* *}\end{array}$ & $\begin{array}{l}0.11651 \\
(3.82) * * *\end{array}$ \\
\hline Remit_RPE & & & $\begin{array}{l}20.24800 \\
(1.70)^{*}\end{array}$ & $\begin{array}{c}17.56403 \\
(1.68)^{*}\end{array}$ \\
\hline Save_RPE & & & $\begin{array}{l}3.35740 \\
(1.25)\end{array}$ & \\
\hline _cons & $\begin{array}{c}-17.32875 \\
(5.44)^{* * *}\end{array}$ & $\begin{array}{c}-16.06104 \\
(5.23)^{* * *}\end{array}$ & $\begin{array}{r}-16.89536 \\
(5.24)^{* * *}\end{array}$ & $\begin{array}{r}-15.44593 \\
(5.03)^{* * * *}\end{array}$ \\
\hline$R^{2}$ & 0.07 & 0.06 & 0.09 & 0.07 \\
\hline$N$ & 1,588 & 1,659 & 1,588 & 1,659 \\
\hline
\end{tabular}


Table D-5: Panel Data Analysis using Fixed-Effects: LDC Sample (Life Expectancy)

\begin{tabular}{|c|c|c|c|c|}
\hline & $\begin{array}{c}\text { Life } \\
\text { Expectancy } \\
{[1]}\end{array}$ & $\begin{array}{c}\text { Life } \\
\text { Expectancy } \\
{[2]}\end{array}$ & $\begin{array}{c}\text { Life } \\
\text { Expectancy } \\
{[3]}\end{array}$ & $\begin{array}{c}\text { Life } \\
\text { Expectancy } \\
{[4]}\end{array}$ \\
\hline FDI_GDP & $\begin{array}{l}7.35565 \\
(3.43)^{* * * *}\end{array}$ & $\begin{array}{l}9.34966 \\
(4.52) * * *\end{array}$ & $\begin{array}{r}22.54765 \\
(4.25)^{* * * * *}\end{array}$ & $\begin{array}{r}22.38832 \\
(4.44)^{* * * *}\end{array}$ \\
\hline FPI_GDP & $\begin{array}{r}7.61173 \\
(0.40)\end{array}$ & $\begin{array}{r}4.99629 \\
(0.26)\end{array}$ & $\begin{array}{r}21.05879 \\
(0.40)\end{array}$ & $\begin{array}{r}15.97855 \\
(0.30)\end{array}$ \\
\hline OFI_GDP & $\begin{array}{r}-1.23919 \\
(2.63)^{* * * *}\end{array}$ & $\begin{array}{r}-1.06985 \\
(2.31)^{* *}\end{array}$ & $\begin{array}{c}-0.48612 \\
(0.47)\end{array}$ & $\begin{array}{r}-0.58769 \\
(0.57)\end{array}$ \\
\hline Remit_GDP & $\begin{array}{l}48.06111 \\
(14.43)^{* * * *}\end{array}$ & $\begin{array}{l}40.63745 \\
(13.98)^{* * * *}\end{array}$ & $\begin{array}{l}47.07692 \\
(14.07) * * * *\end{array}$ & $\begin{array}{l}40.14494 \\
(13.80)^{* * * *}\end{array}$ \\
\hline ODA_GDP & $\begin{array}{r}0.00000 \\
(0.66)\end{array}$ & $\begin{array}{c}-0.00000 \\
(0.41)\end{array}$ & $\begin{array}{r}0.00000 \\
(0.52)\end{array}$ & $\begin{array}{r}-0.00000 \\
(0.59)\end{array}$ \\
\hline CAofgdp & $\begin{array}{r}-0.02690 \\
(2.94)^{* * * * *}\end{array}$ & $\begin{array}{r}-0.01539 \\
(2.18)^{* *}\end{array}$ & $\begin{array}{r}-0.01988 \\
(0.98)\end{array}$ & $\begin{array}{r}-0.03026 \\
(3.37) * * * *\end{array}$ \\
\hline Save_GDP & $\begin{array}{r}1.45601 \\
(2.04)^{* * *}\end{array}$ & & $\begin{array}{r}-0.77965 \\
(0.43)\end{array}$ & \\
\hline RPE & $\begin{array}{r}0.22741 \\
(0.87)\end{array}$ & $\begin{array}{r}0.19467 \\
(0.77)\end{array}$ & $\begin{array}{r}0.32785 \\
(1.02)\end{array}$ & $\begin{array}{r}0.55867 \\
(2.08)^{* * *}\end{array}$ \\
\hline work & $\begin{array}{r}3.36477 \\
(2.17)^{* * *}\end{array}$ & $\begin{array}{l}4.81520 \\
(3.15)^{* * * *}\end{array}$ & $\begin{array}{r}3.50706 \\
(2.25)^{* * *}\end{array}$ & $\begin{array}{l}4.71873 \\
(3.07)^{* * * *}\end{array}$ \\
\hline second & $\begin{array}{r}0.00939 \\
(14.35)^{* * * *}\end{array}$ & $\begin{array}{r}0.00871 \\
(13.23)^{* * * *}\end{array}$ & $\begin{array}{r}0.00942 \\
(14.41)^{* * * *}\end{array}$ & $\begin{array}{r}0.00865 \\
(13.20)^{* * * *}\end{array}$ \\
\hline FDI_RPE & & & $\begin{array}{r}-12.34757 \\
(2.89)^{* * * *}\end{array}$ & $\begin{array}{r}-10.81200 \\
(2.61)^{* * * * *}\end{array}$ \\
\hline FPI_RPE & & & $\begin{array}{c}-6.75875 \\
(0.14)\end{array}$ & $\begin{array}{r}-5.20618 \\
(0.11)\end{array}$ \\
\hline OFI_RPE & & & $\begin{array}{r}-1.02917 \\
(0.83)\end{array}$ & $\begin{array}{r}-0.68470 \\
(0.57)\end{array}$ \\
\hline CA_RPE & & & $\begin{array}{r}0.00586 \\
(0.32)\end{array}$ & $\begin{array}{r}0.02547 \\
(2.42)^{* *}\end{array}$ \\
\hline Save_RPE & & & $\begin{array}{r}2.09883 \\
(1.57)\end{array}$ & \\
\hline _cons & $\begin{array}{l}52.84095 \\
(59.14)^{* * * *}\end{array}$ & $\begin{array}{l}52.55796 \\
(59.73) * * * *\end{array}$ & $\begin{array}{l}52.70583 \\
(58.28) * * * *\end{array}$ & $\begin{array}{l}52.31658 \\
(59.29)^{* * * *}\end{array}$ \\
\hline$R^{2}$ & 0.26 & 0.23 & 0.27 & 0.24 \\
\hline$N$ & 1,599 & 1,679 & 1,599 & 1,679 \\
\hline
\end{tabular}




\section{Appendix E - Statistical Tables Cross Section Results}

Table E-1: Cross Section Regression: 1980-1990

Table E-2: Cross Section Regression: 1990-2000

Table E-3: Cross Section Regression: 2000-2007 $\ldots 115$ 
Table E-1: Cross Section Regression: 1980-1990

\begin{tabular}{|c|c|c|c|c|}
\hline & $\begin{array}{c}\text { Gy80_90 } \\
{[1]}\end{array}$ & $\begin{array}{c}\text { [Gy80_90 } \\
{[2]}\end{array}$ & $\begin{array}{c}\text { Gy80_90 } \\
\text { [3] }\end{array}$ & $\begin{array}{c}\text { Gy80_90 } \\
\text { [4] }\end{array}$ \\
\hline GDP_1980cap2000 & $\begin{array}{r}0.00001 \\
(2.26)^{* * *}\end{array}$ & $\begin{array}{l}0.00001 \\
(2.48)^{* *}\end{array}$ & $\begin{array}{l}0.00001 \\
(1.69)\end{array}$ & $\begin{array}{c}0.00001 \\
(1.80)^{*}\end{array}$ \\
\hline Life expectancy & $\begin{array}{l}0.01435 \\
(5.15)^{* * *}\end{array}$ & $\begin{array}{c}0.01335 \\
(5.03)^{* * *}\end{array}$ & $\begin{array}{c}0.01320 \\
(4.19)^{* * *}\end{array}$ & $\begin{array}{l}0.01436 \\
(5.23)^{* * *}\end{array}$ \\
\hline FDI_GDP_1980 & $\begin{array}{r}2.35015 \\
(2.63)^{* *}\end{array}$ & $\begin{array}{l}2.56957 \\
(3.12)^{* * *}\end{array}$ & $\begin{array}{l}2.23530 \\
(0.61)\end{array}$ & $\begin{array}{c}4.68722 \\
(1.54)\end{array}$ \\
\hline FPI_GDP_1980 & $\begin{array}{r}-10.71693 \\
(1.31)\end{array}$ & $\begin{array}{c}-11.30804 \\
(1.40)\end{array}$ & $\begin{array}{l}0.15013 \\
(0.01)\end{array}$ & $\begin{array}{c}-0.04877 \\
(0.00)\end{array}$ \\
\hline Remit_GDP_1980 & $\begin{array}{r}0.62705 \\
(1.00)\end{array}$ & $\begin{array}{l}0.48400 \\
(0.78)\end{array}$ & $\begin{array}{l}-2.32844 \\
(1.07)\end{array}$ & $\begin{array}{c}-2.78880 \\
(1.42)\end{array}$ \\
\hline OFI_GDP_1980 & $\begin{array}{r}0.40637 \\
(0.78)\end{array}$ & $\begin{array}{l}0.26074 \\
(0.52)\end{array}$ & $\begin{array}{l}-0.11816 \\
(0.07)\end{array}$ & $\begin{array}{c}-0.50187 \\
(0.36)\end{array}$ \\
\hline CAofGDP_1980 & $\begin{array}{r}0.00587 \\
(1.53)\end{array}$ & $\begin{array}{l}0.00457 \\
(1.67)\end{array}$ & $\begin{array}{l}-0.00569 \\
(0.53)\end{array}$ & $\begin{array}{c}0.00232 \\
(0.44)\end{array}$ \\
\hline RPE_1980 & $\begin{array}{r}-0.09696 \\
(2.44)^{* *}\end{array}$ & $\begin{array}{l}-0.10107 \\
(2.53)^{* *}\end{array}$ & $\begin{array}{l}0.01747 \\
(0.13)\end{array}$ & $\begin{array}{c}-0.11542 \\
(1.29)\end{array}$ \\
\hline Save_GDP_1980 & $\begin{array}{r}0.08737 \\
(0.36)\end{array}$ & & $\begin{array}{l}1.12880 \\
(1.29)\end{array}$ & \\
\hline laborforcetotal_1980 & $\begin{array}{c}0.00000 \\
(0.34)\end{array}$ & $\begin{array}{l}0.00000 \\
(0.16)\end{array}$ & $\begin{array}{l}0.00000 \\
(0.18)\end{array}$ & $\begin{array}{c}0.00000 \\
(0.12)\end{array}$ \\
\hline FDI_RPE_1980 & & & $\begin{array}{l}-0.82091 \\
(0.21)\end{array}$ & $\begin{array}{c}-2.83073 \\
(0.86)\end{array}$ \\
\hline FPI_RPE_1980 & & & $\begin{array}{c}-16.86396 \\
(0.67)\end{array}$ & $\begin{array}{c}-16.08907 \\
(0.70)\end{array}$ \\
\hline CA_RPE_1980 & & & $\begin{array}{l}0.01002 \\
(1.18)\end{array}$ & $\begin{array}{c}0.00282 \\
(0.71)\end{array}$ \\
\hline Remit_RPE_1980 & & & $\begin{array}{l}1.95145 \\
(1.29)\end{array}$ & $\begin{array}{c}2.44865 \\
(1.80)^{*}\end{array}$ \\
\hline OFI_RPE_1980 & & & $\begin{array}{l}0.26103 \\
(0.22)\end{array}$ & $\begin{array}{c}0.57367 \\
(0.54)\end{array}$ \\
\hline Save_RPE_1980 & & & $\begin{array}{l}-0.80104 \\
(1.30)\end{array}$ & \\
\hline Constant & $\begin{array}{r}-0.28946 \\
(1.74)^{*}\end{array}$ & $\begin{array}{l}-0.20768 \\
(1.31)\end{array}$ & $\begin{array}{l}-0.31311 \\
(1.62)\end{array}$ & $\begin{array}{c}-0.22086 \\
(1.26)\end{array}$ \\
\hline F statistic & 13.4 & 14.4 & 8.3 & 9.7 \\
\hline Adjusted R-squared & 0.75 & 0.74 & 0.74 & 0.74 \\
\hline
\end{tabular}

$* p<0.1 ; * * p<0.05 ; * * * p<0.01$ 
Table E-2: Cross Section Regression: 1990-2000

\begin{tabular}{|c|c|c|c|c|}
\hline & $\begin{array}{c}\text { Gy90_00 } \\
{[1]}\end{array}$ & $\begin{array}{c}\text { Gy90_00 } \\
{[2]}\end{array}$ & $\begin{array}{c}\text { Gy90_00 } \\
\text { [3] }\end{array}$ & $\begin{array}{l}\text { Gy90_00 } \\
\text { [4] }\end{array}$ \\
\hline GDP_1990cap2000 & $\begin{array}{c}0.00001 \\
(4.20)^{* * *}\end{array}$ & $\begin{array}{c}0.00001 \\
(3.51)^{* * *}\end{array}$ & $\begin{array}{l}0.00001 \\
(3.90)^{* * *}\end{array}$ & $\begin{array}{l}0.00001 \\
(3.25)^{* * *}\end{array}$ \\
\hline Life expectancy & $\begin{array}{c}0.01066 \\
(7.28)^{* * *}\end{array}$ & $\begin{array}{c}0.01134 \\
(7.58) * * *\end{array}$ & $\begin{array}{c}0.00980 \\
(5.72)^{* * *}\end{array}$ & $\begin{array}{l}0.01125 \\
(6.60)^{* * *}\end{array}$ \\
\hline FDI_GDP_1990 & $\begin{array}{l}0.21996 \\
(0.27)\end{array}$ & $\begin{array}{l}0.14053 \\
(0.17)\end{array}$ & $\begin{array}{l}-1.03301 \\
(0.35)\end{array}$ & $\begin{array}{c}0.62684 \\
(0.26)\end{array}$ \\
\hline FPI_GDP_1990 & $\begin{array}{l}7.64754 \\
(1.99)^{*}\end{array}$ & $\begin{array}{l}6.88500 \\
(1.72)^{*}\end{array}$ & $\begin{array}{l}11.15905 \\
(0.77)\end{array}$ & $\begin{array}{c}7.63396 \\
(0.50)\end{array}$ \\
\hline Remit_GDP_1990 & $\begin{array}{l}-0.39040 \\
(1.09)\end{array}$ & $\begin{array}{l}-0.52845 \\
(1.42)\end{array}$ & $\begin{array}{l}0.67763 \\
(0.50)\end{array}$ & $\begin{array}{c}0.13796 \\
(0.10)\end{array}$ \\
\hline OFI_GDP_1990 & $\begin{array}{l}-0.02765 \\
(0.82)\end{array}$ & $\begin{array}{l}-0.02257 \\
(0.64)\end{array}$ & $\begin{array}{l}-0.02880 \\
(0.39)\end{array}$ & $\begin{array}{c}-0.03230 \\
(0.46)\end{array}$ \\
\hline CAofGDP_1990 & $\begin{array}{l}0.00125 \\
(0.74)\end{array}$ & $\begin{array}{l}0.00315 \\
(2.04)^{* *}\end{array}$ & $\begin{array}{l}0.00300 \\
(0.92)\end{array}$ & $\begin{array}{c}0.00431 \\
(1.27)\end{array}$ \\
\hline RPE_1990 & $\begin{array}{l}-0.06238 \\
(2.44)^{* * *}\end{array}$ & $\begin{array}{l}-0.03490 \\
(1.65)\end{array}$ & $\begin{array}{l}-0.00753 \\
(0.15)\end{array}$ & $\begin{array}{c}-0.01412 \\
(0.29)\end{array}$ \\
\hline Save_GDP_1990 & $\begin{array}{l}0.21936 \\
(1.71)^{*}\end{array}$ & & $\begin{array}{l}0.58535 \\
(2.28)^{* *}\end{array}$ & \\
\hline laborforcetotal_1990 & $\begin{array}{l}-0.00000 \\
(0.66)\end{array}$ & $\begin{array}{l}-0.00000 \\
(0.53)\end{array}$ & $\begin{array}{l}-0.00000 \\
(0.95)\end{array}$ & $\begin{array}{c}-0.00000 \\
(0.51)\end{array}$ \\
\hline FDI_RPE_1990 & & & $\begin{array}{l}1.10375 \\
(0.40)\end{array}$ & $\begin{array}{c}-0.52728 \\
(0.24)\end{array}$ \\
\hline FPI_RPE_1990 & & & $\begin{array}{l}-3.13648 \\
(0.20)\end{array}$ & $\begin{array}{c}-0.64130 \\
(0.04)\end{array}$ \\
\hline CA_RPE_1990 & & & $\begin{array}{l}-0.00018 \\
(0.07)\end{array}$ & $\begin{array}{c}-0.00059 \\
(0.23)\end{array}$ \\
\hline Remit_RPE_1990 & & & $\begin{array}{l}-1.07356 \\
(0.97)\end{array}$ & $\begin{array}{c}-0.60621 \\
(0.53)\end{array}$ \\
\hline OFI_RPE_1990 & & & $\begin{array}{l}-0.00478 \\
(0.03)\end{array}$ & $\begin{array}{c}-0.02769 \\
(0.16)\end{array}$ \\
\hline Save_RPE_1990 & & & $\begin{array}{l}-0.24181 \\
(1.47)\end{array}$ & \\
\hline Constant & $\begin{array}{l}-0.09422 \\
(1.03)\end{array}$ & $\begin{array}{l}-0.12591 \\
(1.35)\end{array}$ & $\begin{array}{l}-0.09138 \\
(0.90)\end{array}$ & $\begin{array}{c}-0.13705 \\
(1.32)\end{array}$ \\
\hline F statistic & 32.2 & 32.8 & 19.3 & 19.3 \\
\hline Adjusted R-squared & 0.84 & 0.83 & 0.83 & 0.81 \\
\hline
\end{tabular}

$* p<0.1 ; * * p<0.05 ; * * * p<0.01$ 
Table E-3: Cross Section Regression: 2000-2007

\begin{tabular}{|c|c|c|c|c|}
\hline & $\begin{array}{c}\text { Gy00_07 } \\
{[1]}\end{array}$ & $\begin{array}{c}\text { Gy00_07 } \\
\text { [2] }\end{array}$ & $\begin{array}{c}\text { Gy00_07 } \\
{[3]}\end{array}$ & $\begin{array}{c}\text { Gy00_07 } \\
\text { [3] }\end{array}$ \\
\hline GDP_2000cap2000 & $\begin{array}{l}0.00001 \\
(2.58)^{* *}\end{array}$ & $\begin{array}{l}0.00001 \\
(2.20)^{* *}\end{array}$ & $\begin{array}{l}0.00001 \\
(2.44)^{* *}\end{array}$ & $\begin{array}{l}0.00001 \\
(2.18)^{* *}\end{array}$ \\
\hline Life expectancy & $\begin{array}{c}0.01144 \\
(5.45)^{* * * *}\end{array}$ & $\begin{array}{c}0.01206 \\
(5.73)^{* * *}\end{array}$ & $\begin{array}{c}0.01140 \\
(4.96)^{* * * *}\end{array}$ & $\begin{array}{r}0.01183 \\
(5.24)^{* * * *}\end{array}$ \\
\hline FDI_GDP_2000 & $\begin{array}{l}0.84097 \\
(1.24)\end{array}$ & $\begin{array}{l}0.78821 \\
(1.15)\end{array}$ & $\begin{array}{l}1.75704 \\
(0.74)\end{array}$ & $\begin{array}{l}1.50521 \\
(0.64)\end{array}$ \\
\hline FPI_GDP_2000 & $\begin{array}{l}-0.12891 \\
(0.44)\end{array}$ & $\begin{array}{l}-0.06712 \\
(0.23)\end{array}$ & $\begin{array}{l}0.70154 \\
(0.10)\end{array}$ & $\begin{array}{l}2.08090 \\
(0.29)\end{array}$ \\
\hline Remit_GDP_2000 & $\begin{array}{l}-0.88110 \\
(1.71)^{*}\end{array}$ & $\begin{array}{l}-0.80870 \\
(1.55)\end{array}$ & $\begin{array}{l}-1.28944 \\
(0.60)\end{array}$ & $\begin{array}{l}-1.13963 \\
(0.54)\end{array}$ \\
\hline OFI_GDP_2000 & $\begin{array}{l}-0.04060 \\
(0.14)\end{array}$ & $\begin{array}{l}0.00865 \\
(0.03)\end{array}$ & $\begin{array}{l}0.53852 \\
(0.59)\end{array}$ & $\begin{array}{l}0.61898 \\
(0.67)\end{array}$ \\
\hline CAofGDP_2000 & $\begin{array}{l}0.00064 \\
(0.20)\end{array}$ & $\begin{array}{l}0.00501 \\
(2.42)^{* *}\end{array}$ & $\begin{array}{l}0.00213 \\
(0.21)\end{array}$ & $\begin{array}{l}0.00362 \\
(0.66)\end{array}$ \\
\hline RPE_2000 & $\begin{array}{l}0.08373 \\
(1.50)\end{array}$ & $\begin{array}{l}0.07070 \\
(1.25)\end{array}$ & $\begin{array}{l}0.07316 \\
(0.47)\end{array}$ & $\begin{array}{l}0.09832 \\
(1.10)\end{array}$ \\
\hline Save_GDP_2000 & $\begin{array}{l}0.56462 \\
(1.95)^{*}\end{array}$ & & $\begin{array}{l}0.22321 \\
(0.21)\end{array}$ & \\
\hline laborforcetotal_2000 & $\begin{array}{l}0.00000 \\
(0.44)\end{array}$ & $\begin{array}{l}0.00000 \\
(0.63)\end{array}$ & $\begin{array}{l}0.00000 \\
(0.45)\end{array}$ & $\begin{array}{l}0.00000 \\
(0.56)\end{array}$ \\
\hline FDI_RPE_2000 & & & $\begin{array}{l}-0.74301 \\
(0.30)\end{array}$ & $\begin{array}{l}-0.41593 \\
(0.17)\end{array}$ \\
\hline FPI_RPE_2000 & & & $\begin{array}{l}-0.70260 \\
(0.11)\end{array}$ & $\begin{array}{l}-1.88158 \\
(0.30)\end{array}$ \\
\hline CA_RPE_2000 & & & $\begin{array}{l}-0.00013 \\
(0.01)\end{array}$ & $\begin{array}{l}0.00300 \\
(0.45)\end{array}$ \\
\hline Remit_RPE_2000 & & & $\begin{array}{l}0.40146 \\
(0.21)\end{array}$ & $\begin{array}{l}0.31458 \\
(0.17)\end{array}$ \\
\hline OFI_RPE_2000 & & & $\begin{array}{l}-0.67239 \\
(0.62)\end{array}$ & $\begin{array}{l}-0.76529 \\
(0.71)\end{array}$ \\
\hline Save_RPE_2000 & & & $\begin{array}{l}0.36021 \\
(0.31)\end{array}$ & \\
\hline Constant & $\begin{array}{l}-0.11763 \\
(0.92)\end{array}$ & $\begin{array}{l}-0.07735 \\
(0.60)\end{array}$ & $\begin{array}{l}-0.10230 \\
(0.59)\end{array}$ & $\begin{array}{l}-0.08817 \\
(0.62)\end{array}$ \\
\hline F statistic & 17.5 & 18.4 & 9.8 & 11.0 \\
\hline Adjusted R-squared & 0.75 & 0.74 & 0.72 & 0.72 \\
\hline
\end{tabular}

$* p<0.1 ; * * p<0.05 ; * * * p<0.01$ 
Appendix F- Correlation Matrix

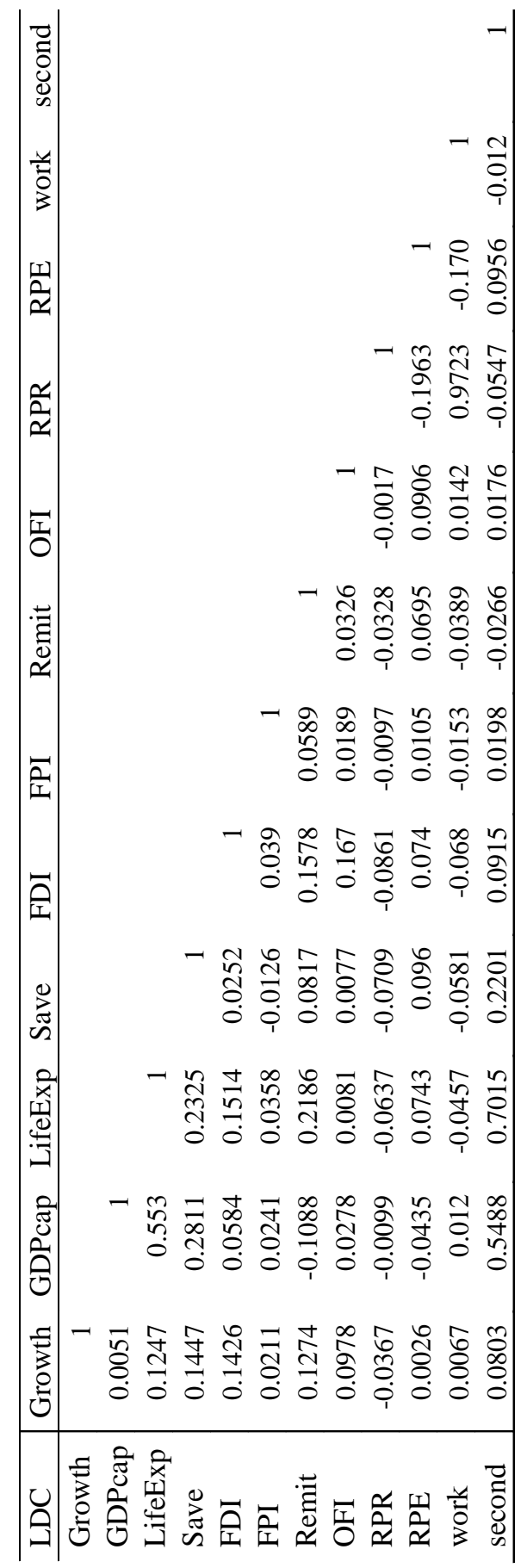

